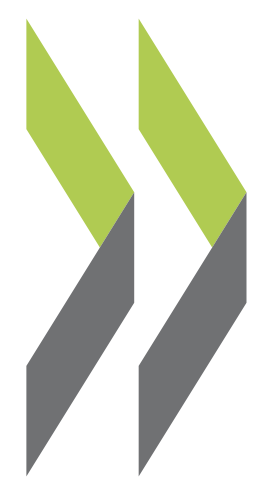

OECD Economics Department Working Papers No. 1172

Better Harnessing Talent and Knowledge to Boost Sustainable Medium-term

\title{
David Haugh,
}

Growth in Spain 
Organisation de Coopération et de Développement Économiques

Organisation for Economic Co-operation and Development

13-Nov-2014

ECONOMICS DEPARTMENT

English - Or. English

BETTER HARNESSING TALENT AND KNOWLEDGE TO BOOST SUSTAINABLE MEDIUM-TERM GROWTH IN SPAIN

ECONOMICS DEPARTMENT WORKING PAPERS No. 1172

By David Haugh and Ben Westmore

OECD Working Papers should not be reported as representing the official views of the OECD or of its member countries. The opinions expressed and arguments employed are those of the authors.

Authorised for publication by Alvaro Pereira, Director, Country Studies Branch, Economics Department.

All Economics Department Working Papers are available through OECD's Internet website at http://www.oecd.org/eco/workingpapers

Complete document available on OLIS in its original format

This document and any map included herein are without prejudice to the status of or sovereignty over any territory, to the delimitation of international frontiers and boundaries and to the name of any territory, city or area. 
OECD Working Papers should not be reported as representing the official views of the OECD or of its member countries. The opinions expressed and arguments employed are those of the author(s).

Working Papers describe preliminary results or research in progress by the author(s) and are published to stimulate discussion on a broad range of issues on which the OECD works.

Comments on Working Papers are welcomed, and may be sent to the Economics Department, OECD, 2 rue André-Pascal, 75775 Paris Cedex 16, France, or by e-mail to eco.contact@oecd.org.

This document and any map included herein are without prejudice to the status of or sovereignty over any territory, to the delimitation of international frontiers and boundaries and to the name of any territory, city or area.

The statistical data for Israel are supplied by and under the responsibility of the relevant Israeli authorities. The use of such data by the OECD is without prejudice to the status of the Golan Heights, East Jerusalem and Israeli settlements in the West Bank under the terms of international law.

\section{(C) OECD (2014)}

You can copy, download or print OECD content for your own use, and you can include excerpts from OECD publications, databases and multimedia products in your own documents, presentations, blogs, websites and teaching materials, provided that suitable acknowledgment of OECD as source and copyright owner is given. All requests for commercial use and translation rights should be submitted to rights@oecd.org 
ECO/WKP(2014)68

\section{ABSTRACT/RÉSUMÉ \\ Better harnessing talent and knowledge to boost sustainable medium-term growth in Spain}

Structural transformation towards a more knowledge-based economy will strengthen Spain's medium-term growth prospects. To deal with long standing impediments to higher growth the government has a substantial structural reform programme touching on education, the labour market and the business environment. Areas of particular weakness to be tackled include the high number of poorly qualified long-term unemployed, skills mismatches and a high school drop-out rate, and insufficient innovation. Spain has done well in reducing the carbon emissions intensity of GDP growth but will need to do more to meet future targets and manage its scarce water resources. The resolution of acute banking and fiscal problems, and the cyclical upswing, provide a more solid platform for sustained growth. Raising trend growth will boost job creation, which is the most effective antidote to the strong rise in poverty and inequality that accompanied the sharp deterioration in the labour market during the crisis.

This Working Paper relates to the 2014 OECD Economic Survey of Spain (http://www.oecd.org/eco/surveys/economic-survey-spain.htm).

JEL classification: E17;E24;I23;I28;J13;J21;J52;J61;J65;O31;O38;O40;Q52;Q58

Keywords: Spain, trend growth, productivity, growth simulations, skills, training, innovation, universities, R\&D, education, long-term unemployment, youth unemployment, skill mismatches, labour participation, active labour market policies, wage bargaining, employment protection, environment, climate change, carbon pricing, water scarcity, green innovation, fertility, family policies, female labour participation.

$* * * * * * * * * * * * * *$

\section{Mieux maîtriser les talents et les connaissances pour stimuler une croissance à moyen terme durable en Espagne}

La transformation structurelle en faveur d'une économie davantage fondée sur le savoir renforcera les perspectives de croissance à moyen terme de l'Espagne. Pour remédier aux obstacles qui entravent de longue date une croissance plus soutenue, les autorités ont mis en place un important programme de réformes structurelles, concernant l'éducation, le marché du travail et l'environnement des entreprises. Parmi les déficiences particulières que ce programme vise à surmonter figurent le grand nombre de chômeurs de longue durée peu qualifiés, les inadéquations de compétences et le taux élevé d'abandon scolaire ainsi que l'insuffisance de l'innovation. L'Espagne a obtenu de bons résultats pour ce qui est de la réduction de l'intensité en émissions de carbone de la croissance du PIB, mais elle devra faire davantage pour atteindre les objectifs futurs et gérer ses rares ressources en eau. La résolution des graves problèmes bancaires et budgétaires et le redressement conjoncturel de l'activité créent des conditions plus propices à une croissance soutenue. L'accélération de la croissance tendancielle dopera la création d'emplois, qui est le meilleur antidote à la forte progression de la pauvreté et de l'inégalité qui a accompagné la profonde dégradation du marché du travail durant la crise.

Ce Document de travail se rapporte à l'Étude économique de l'OCDE de l'Espagne, 2014 (http://www.oecd.org/fr/eco/etudes/espagne.htm).

Classification JEL : E17;E24;I23;I28;J13;J21;J52;J61;J65;O31;O38;O40;Q52;Q58

Mots clefs : : Espagne, croissance tendancielle, productivité, simulations de croissance, compétences, formation, innovation, universités, R-D, éducation, chômage de longue durée, chômage des jeunes, inadéquation des compétences, participation, politiques actives du marché du travail, négociation salariale, protection de l'emploi, environnement, le changement climatique, tarification du carbone, la rareté de l'eau, l'innovation verte, la fertilité, les politiques familiales, la participation de la main-d'œuvre féminine. 


\section{TABLE OF CONTENTS}

Better harnessing talent and knowledge to boost sustainable medium-term growth in Spain ......................6

How well is Spain placed to grow in the medium-term? ..................................................................... 6

Boosting productivity sustainably: towards a more innovative, greener and educated economy ................9

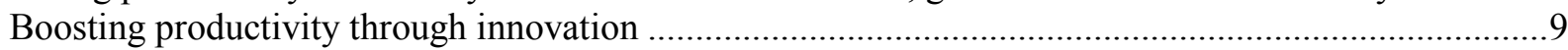

Increasing the capacity and quality of the research base by improving the funding mix ..................12

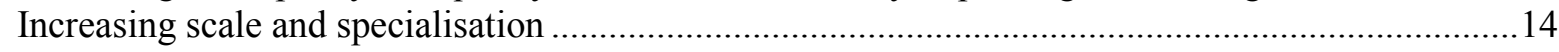

Improving human resources management and university governance ............................................16

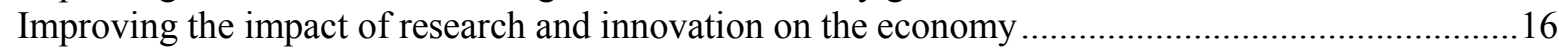

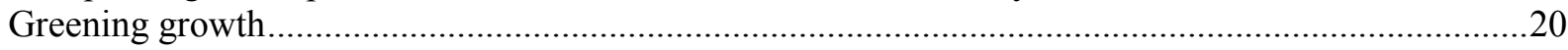

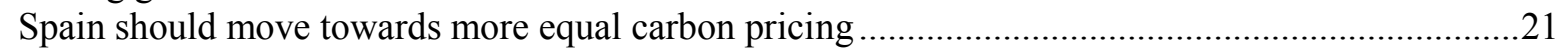

Pricing tools should play a larger role in managing water scarcity .................................................24

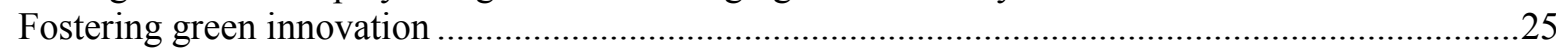

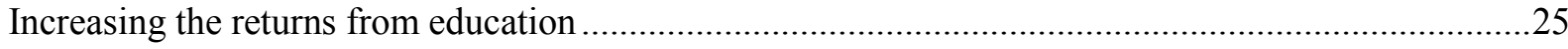

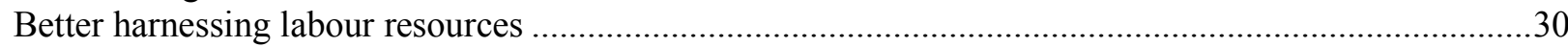

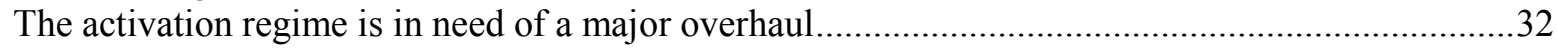

The wage bargaining system is in transition and wage responsiveness can be further enhanced .......35

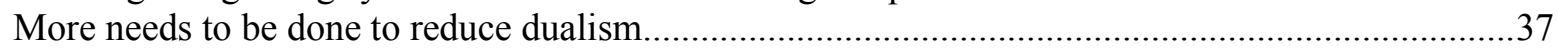

Improving labour mobility can help to reduce unemployment...................................................... 38

A more family friendly labour market: boosting employment of women .........................................41

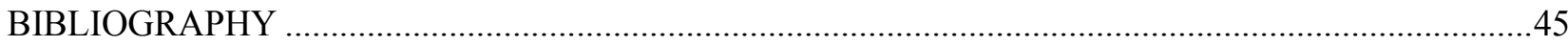

ANNEX 1.A1 MEDIUM-TERM GROWTH SIMULATIONS ….........................................................50

\section{Tables}

1. Spain's national and regional innovation system in international perspective ...............................11

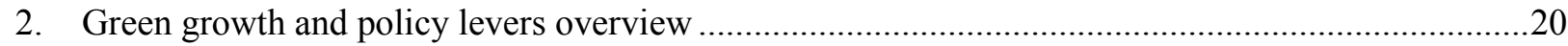

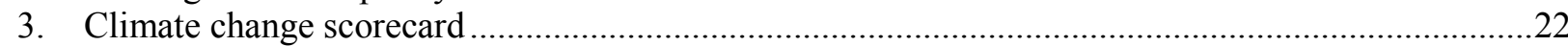

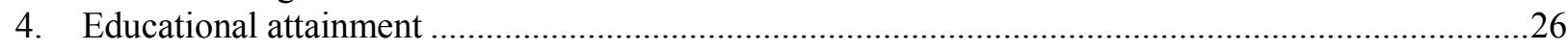

5. Average caseload in the public employment service ........................................................................

6. Working environment for families: Spain in international comparison ...........................................43

\section{Figures}

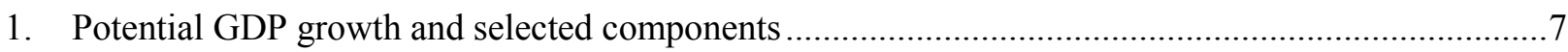

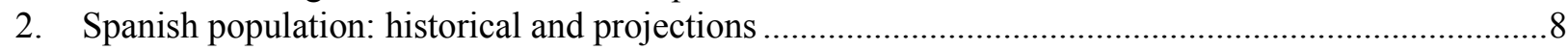

3. Boosting growth through reform: Long-run GDP per capita scenarios.......................................... 8

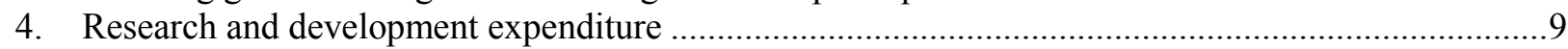

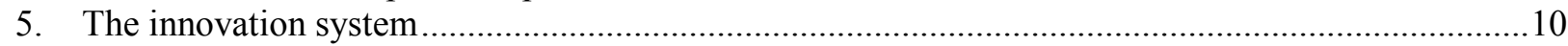

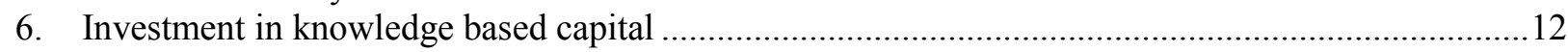

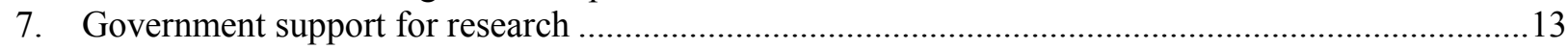

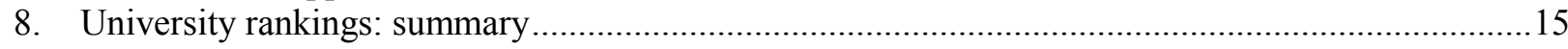

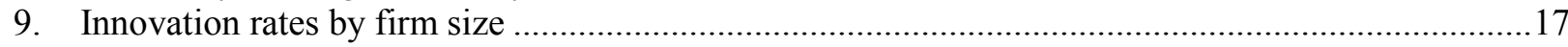

10. Tax subsidy rates on research and development expenditure ….................................................18

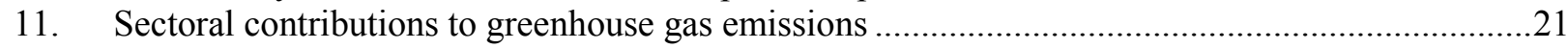

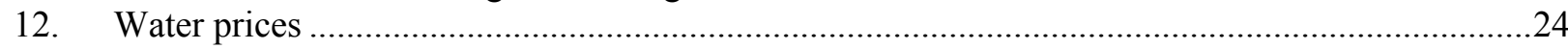




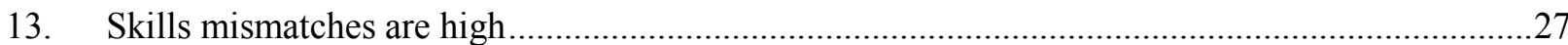

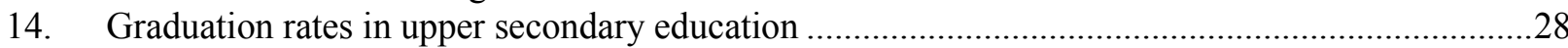

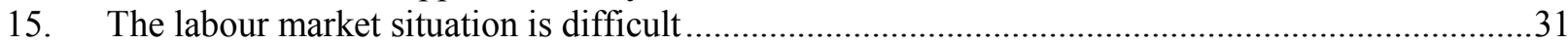

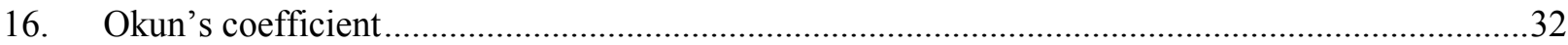

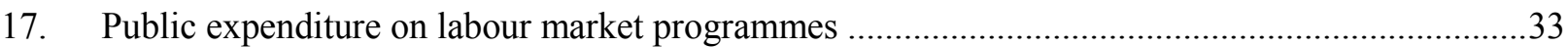

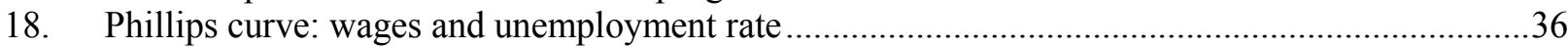

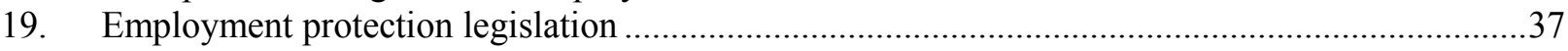

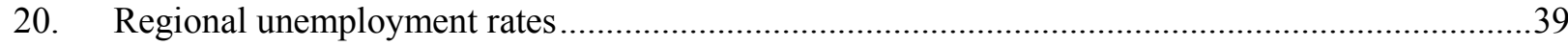

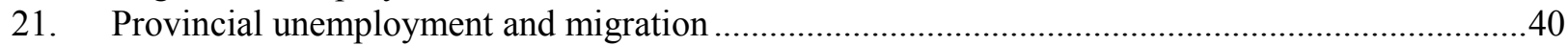

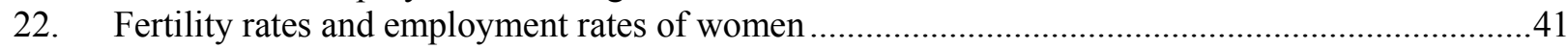

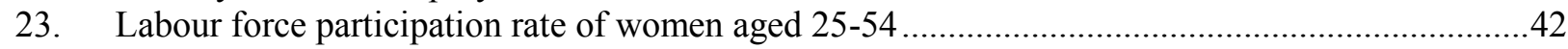

\section{Boxes}

Box 1. Recommendations for sustainable boosting medium-term growth 


\title{
BETTER HARNESSING TALENT AND KNOWLEDGE TO BOOST SUSTAINABLE MEDIUM-TERM GROWTH IN SPAIN
}

\author{
By David Haugh and Ben Westmore ${ }^{1}$
}

\begin{abstract}
In order to sustainably recover from its economic, fiscal and jobs crisis Spain must build its mediumterm capability to generate gross domestic product (GDP) growth. It would make improving living standards and reducing unemployment, inequality, poverty, the fiscal deficit and public debt easier. An inflexible and dualistic labour market and an inadequate regulatory environment for business (Gonzalez Pandiella, 2014) have contributed to the low productivity growth rate (Dolado et al., 2011; Mora-Sanguinetti and Fuentes, 2012). This has been compounded by insufficient investment in innovation, which is closely linked with productivity performance (Hall et al., 2010; Westmore, 2013). Skill mismatches and a high drop-out rate are impeding the contribution of education to growth. If Spain's fertility rate remains at its current low level the working age population will likely shrink markedly with strong implications for growth and the fiscal position due to ageing. The government has a large structural reform programme underway to boost growth including through improving the business environment (Gonzalez Pandiella, 2014), reforms to education and the labour market. However, it will need to maintain reform momentum as well as intensify its focus on areas of strong under-performance compared with OECD peers, including activating the unemployed and boosting innovation.
\end{abstract}

\section{How well is Spain placed to grow in the medium-term?}

Over the decade leading up to the crisis, Spain's trend growth rate was above the OECD median (Figure 1). Growth was driven by strong increases in the supply of human and physical capital, although total factor productivity growth remained consistently and worryingly negative. Low productivity was largely due to poor within sector productivity performance across a wide range of sectors rather than specialisation in sectors that tend to have low productivity (Mora-Sanguinetti and Fuentes, 2012). This suggests that Spain's growth performance has been impeded by barriers that have a broad detrimental effect on business sector performance (Gonzalez Pandiella, 2014). The strong contribution to medium-term growth from increased labour supply rather than productivity partially explains why, despite strong trend GDP growth, Spain was performing less well in generating higher living standards, as evidenced by per capita GDP growth well below the OECD median from 2002 onwards. Despite good progress in tackling greenhouse gas emissions, pre-crisis growth came at environmental cost affecting natural habitats, a high growth in urban sprawl (OECD, 2011a), and the construction of new buildings with low energy efficiency.

1. David Haugh is a Senior Economist and Head of the Ireland/Spain desk in the Country Studies Branch of the Economics Department of the OECD, contact email: David.Haugh@,oecd.org. Ben Westmore is an Economist in the Country Studies Branch of the Economics Department of the OECD. This paper was prepared for the OECD Economic Survey of Spain published in September 2014 under the authority of the Economic and Development Review Committee. The authors would like to thank to Pierre Beynet, Alberto Gonzalez Pandiella, Nils Axel Braathen, Krzysztof Michalak, Alvaro Pereira, Robert Ford and Spanish government officials for their valuable comments and suggestions. Special thanks are due to Desney Erb for statistical assistance and Dacil Kurzweg for technical preparation. 
Figure 1. Potential GDP growth and selected components

Percentage growth
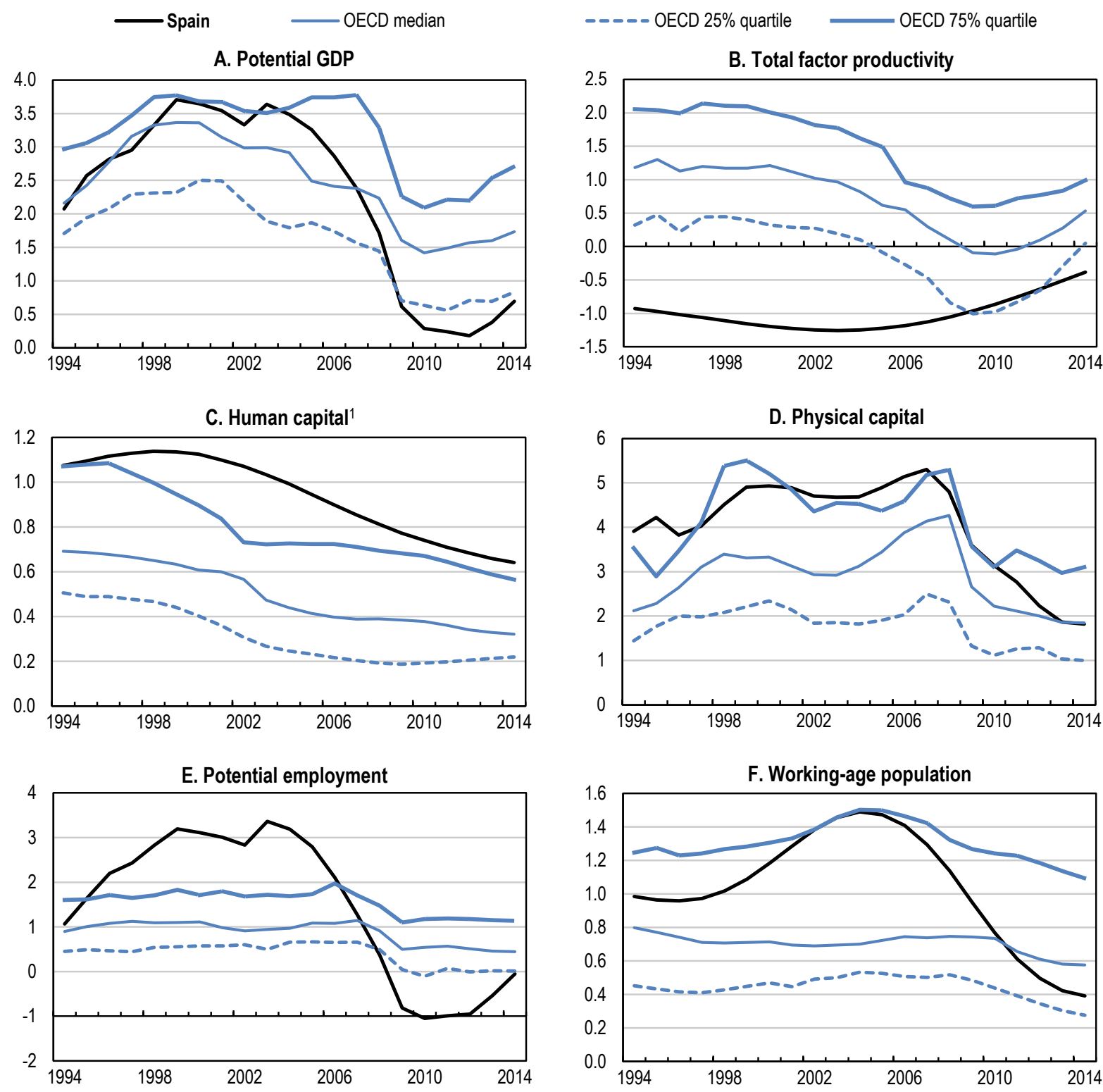

1. Average years of schooling of the population aged 25-64 adjusted by returns to education.

Source: OECD (2014), "OECD Economic Outlook No. 95", OECD Economic Outlook: Statistics and Projections (database).

Following the crisis, trend GDP growth is estimated to have collapsed to below $1 \%$ per annum, in the bottom quartile of the OECD. Total factor productivity growth remains negative and the contribution from human and physical capital growth has declined. Temporary factors that boosted labour supply prior to the crisis have disappeared or gone into reverse. Increased labour force participation, particularly due to increased entry into the workforce of women has plateaued. Net inward migration of more than half a million per year accounted for around $90 \%$ of the total population increase from 1998 to 2007, but turned negative after the crisis. Net outward migration combined with the accumulated effects of persistently low fertility mean that the level of core working-age population peaked around 2009 and is projected to steadily decline (Figure 2). While the recovery now underway will help to partially arrest and turn around migration and participation trends, the probability of a repeat of the pre-crisis boom in labour supply lifting trend growth seems remote. 
Figure 2. Spanish population: historical and projections

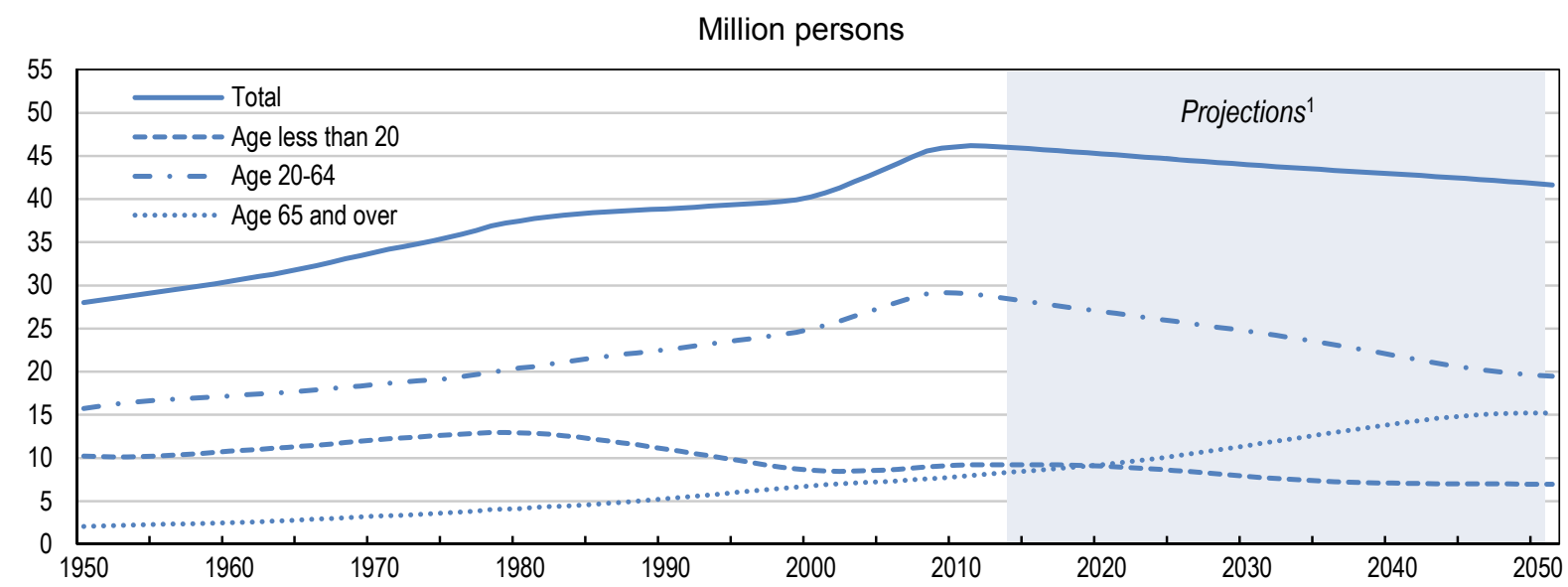

1. Eurostat baseline variant.

Source: OECD (2014), "Historical Population Data and Projections (1950-2050)", Demography and Population (database), July.

Sustainably lifting trend growth in Spain post crisis requires meeting three challenges: raising sustainable medium-term productivity growth by better harnessing talent and knowledge and putting the environment more at the centre of policy making; utilising existing labour resources more efficiently by reducing high structural unemployment and labour market duality; and in the longer run boosting trend labour supply by increasing the participation of women in the labour force by making it easier to balance family and work. To meet these challenges, the government will need to build on its significant structural reform efforts to date.

The payoffs from these reforms are potentially large. Simulations of the OECD's long-term growth model indicate that combined reforms that moved the non-accelerating inflation rate of unemployment (NAIRU), schooling and business research and development (R\&D) to the OECD median by 2035 would raise Spanish GDP per capita by around $12 \%$ by 2025 and $17 \%$ by 2035 and $27 \%$ by 2060 (Figure 3). In the shorter run lowering the NAIRU and getting people back into work faster is likely to give the biggest boost to GDP. Increasing schooling and R\&D would have sustained medium-run payoffs. OECD empirical work shows that investing in innovation is strongly linked with increasing productivity and growth (Box, 2009). Assuming business R\&D in Spain moved to the median or 75\% percentile of the OECD by 2035, Spain's GDP per capita would be higher by $11 \%$ and $18 \%$ respectively by 2060 (Annex 1 .A1).

Figure 3. Boosting growth through reform: Long-run GDP per capita scenarios ${ }^{1}$

Deviation from baseline

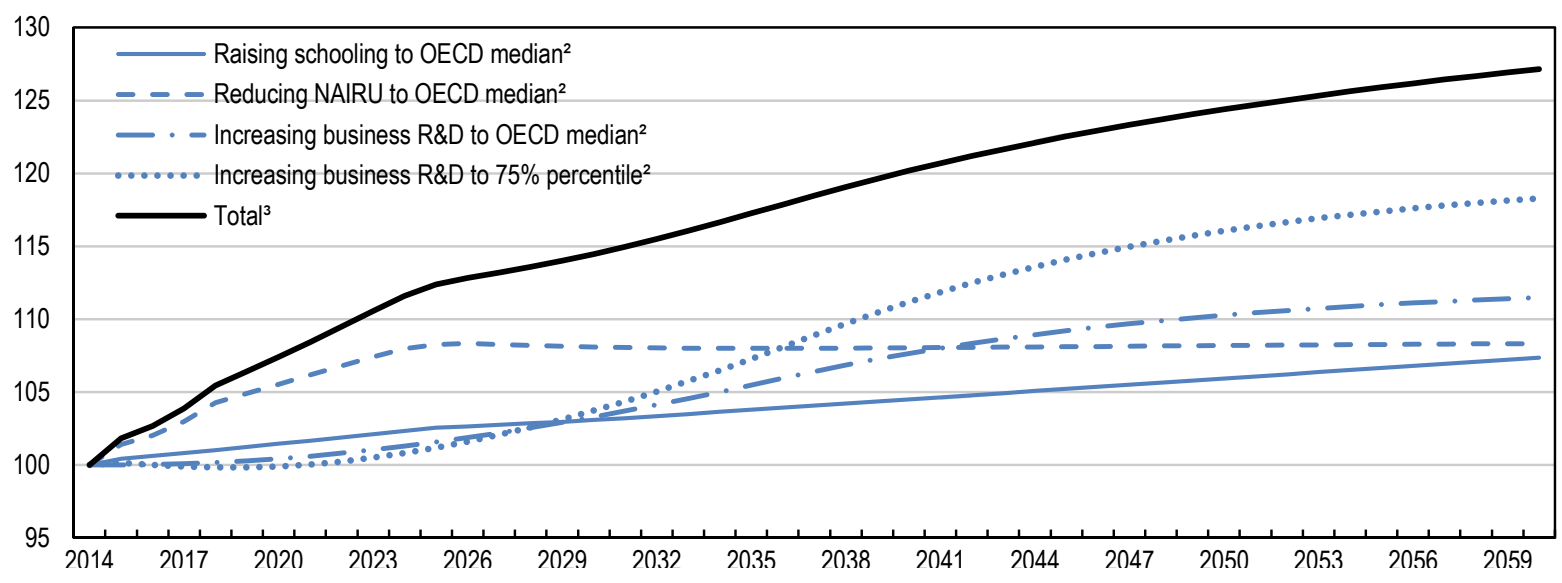

1. For a description of the model see A. Johansson, et al. (2013), "Long-Term Growth Scenarios", OECD Economics Department Working Papers, No. 1000 and D. Andrews and B. Westmore (2014), "Managerial Capital and Business R\&D as Enablers of Productivity Convergence", OECD Economics Department Working Papers, No. 1137.

2. By 2035.

3. Sum of the schooling, NAIRU (non-accelerating inflation rate of unemployment) and median R\&D (research and development) scenarios.

Source: Simulations using the OECD's long-term growth model. 
Boosting productivity sustainably: towards a more innovative, greener and educated economy

\section{Boosting productivity through innovation}

Research, development and innovation (RD\&I) policy is shared between the central government and the 17 regions, each with its own innovation strategy and policy instruments. Recent efforts to increase coordination have been incorporated in the Spanish Strategy for Science, Technology and Innovation. The Council for Science, Technology and Innovation policies has been created to improve the governance of the innovation system. At a central government level the overall aim of current and previous RD\&I policy has been to expand the Spanish innovation system in terms of research capabilities, human resources for research, innovation outputs and linkages between science and industry from overall relatively low levels towards and beyond advanced country averages (Government of Spain, 2013).

Spain has made progress towards these goals, increasing its innovation inputs, capabilities and outputs. Since 2000, both gross expenditure on R\&D (GERD) and business enterprise expenditure on R\&D (BERD) have risen as a share of GDP (Figure 4). Spain has increased the number of scientific and engineering articles, and raised the proportion of researchers employed in the economy (Figure 5). It has also developed strong expertise in several scientific domains including energy and materials (European Commission, 2013). However, as discussed below, cuts in public funding for innovation post-crisis are likely to slow progress in coming years.

Figure 4. Research and development expenditure

Gross domestic expenditure in per cent of GDP
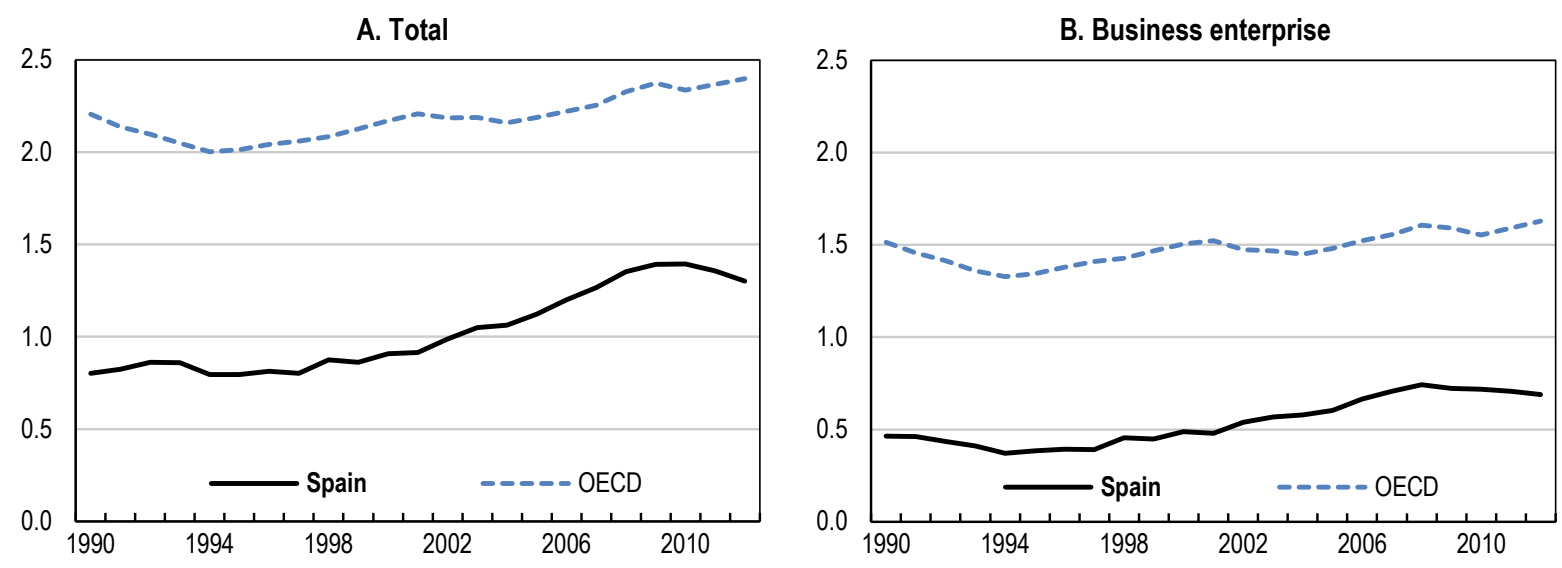

C. By sector of performance

$2012^{1}$

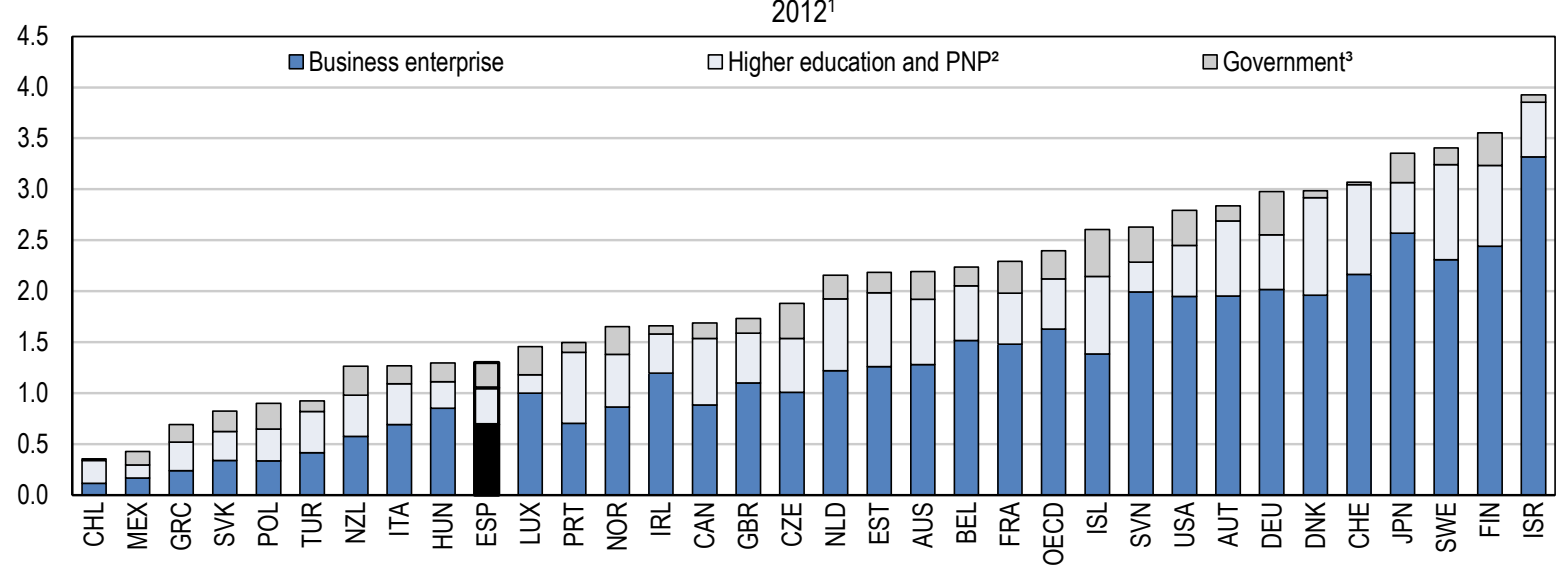

1. 2011 for Iceland, Mexico and New Zealand; 2010 for Australia.

2. PNP: private non-profit sector.

3. Government intramural expenditure.

Source: OECD (2014), "Main Science and Technology Indicators", OECD Science, Technology and R\&D Statistics (database), July. 
Figure 5. The innovation system ${ }^{1}$

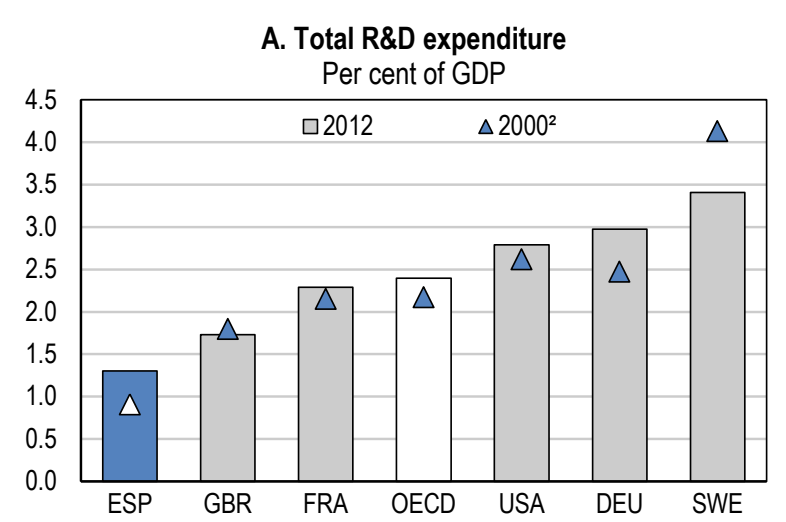

C. Graduation rates at doctoral level

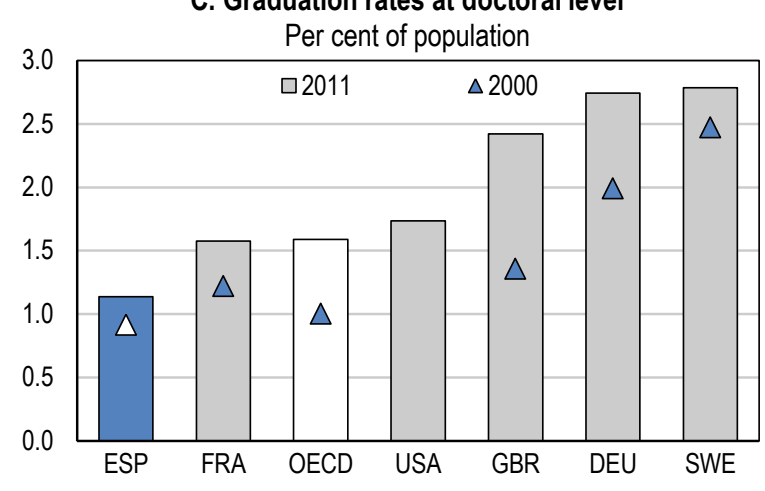

E. Number of S\&E articles

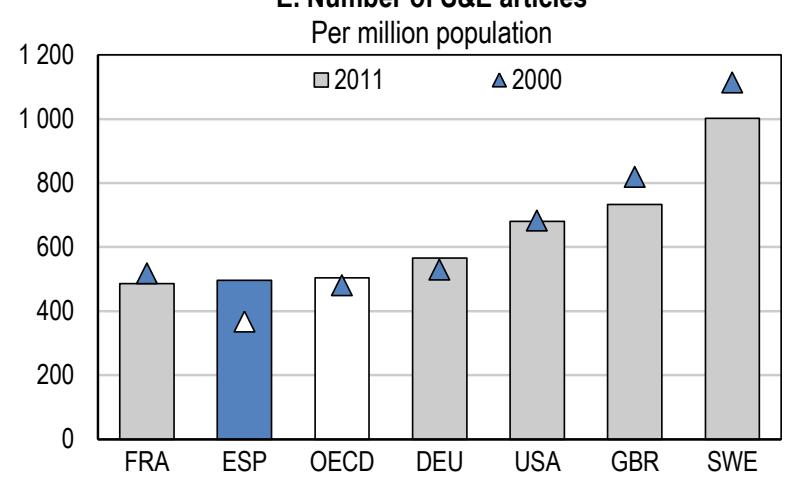

B. Business enterprise R\&D expenditure Per cent of GDP

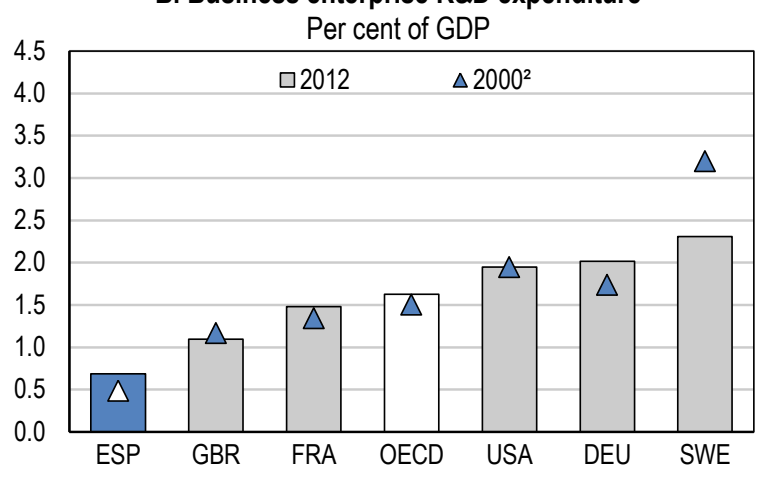

D. Researchers

Per 1000 employed persons

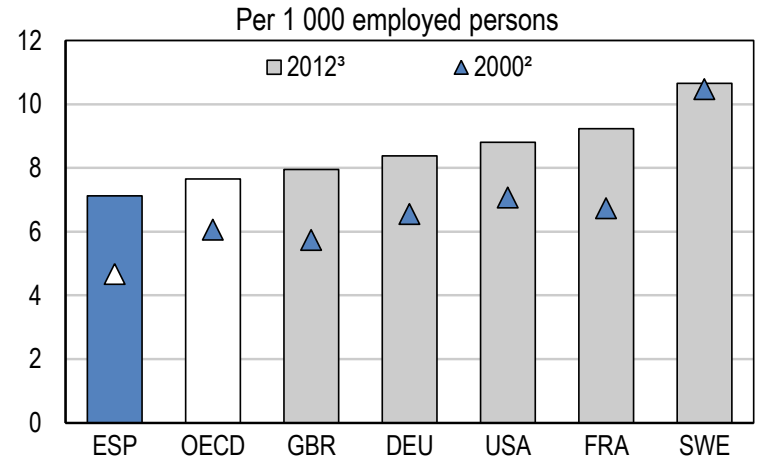

F. Number of triadic patents ${ }^{4}$

Per million population

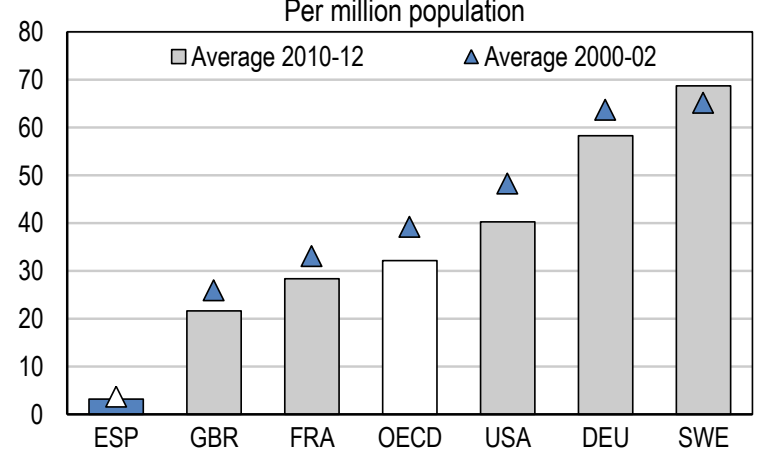

1. R\&D: research and development; S\&E: science and engineering.

2. 2001 for Sweden.

3. 2011 for France, United States and OECD.

4. Patents filed at the both the European and Japanese Patent Offices, and granted by the US Patent and Trademark Office.

Source: OECD (2014), OECD Science, Technology and R\&D Statistics (database), July; OECD (2013), OECD Science, Technology and Industry Scoreboard 2013; and NSF (2014), Science and Engineering Indicators 2014, National Science Foundation.

A distinctive feature of innovation in Spain is the role of regions in innovation policy and its heterogeneous performance. Five of the 17 regions (Andalusia, Basque Country, Catalonia, Madrid and Valencia) account for over $75 \%$ of total R\&D spending (Table 1.1). The core of Spain's innovation strength lies in the Basque Country, Catalonia and Madrid with some pockets elsewhere. Madrid has a high proportion of knowledge-intensive services employment by international standards and the highest in Spain. The Basque Country, along with neighbouring Navarra, appears to have the strongest business-orientated innovation system and has technological strengths in machinery and equipment. Business R\&D is double the national average in both and also in the top $25 \%$ of OECD regions and countries. Catalonia stands out less on any 
single indicator but scores above the national average on all of them and is technologically strong in pharmaceuticals and food chemistry.

Table 1. Spain's national and regional innovation system in international perspective ${ }^{1}$

\begin{tabular}{|c|c|c|c|c|c|c|c|c|c|c|}
\hline \multirow[b]{2}{*}{ Indicator } & \multirow[b]{2}{*}{ Unit } & \multirow[b]{2}{*}{ Year } & \multirow{2}{*}{$\begin{array}{c}\text { OECD } \\
\text { regions } \\
\text { 25th-75th } \\
\text { percentile }\end{array}$} & \multicolumn{7}{|c|}{ Spain } \\
\hline & & & & Total & Andalusia & $\begin{array}{l}\text { Basque } \\
\text { Country }\end{array}$ & Catalonia & Madrid & Navarra & Valencia \\
\hline R\&D expenditure spent in Spain & $\%$ of total & 2010 & & 100.0 & 11.8 & 8.9 & 22.1 & 26.4 & 2.5 & 7.4 \\
\hline$R \& D$ expenditure & $\%$ of GDP & 2009 & $0.9-2.2$ & 1.4 & 1.1 & 2.1 & 1.7 & 2.1 & 2.2 & 1.1 \\
\hline $\begin{array}{l}\text { Business sector R\&D } \\
\text { expenditure }\end{array}$ & $\%$ of GDP & 2009 & $0.3-1.4$ & 0.7 & 0.4 & 1.6 & 1.0 & 1.1 & 1.5 & 0.5 \\
\hline Tertiary qualified personnel & $\%$ of labour force & 2011 & $20-32$ & 34.0 & 27.6 & 49.6 & 33.9 & 44.0 & 43.1 & 31.4 \\
\hline R\&D personnel & $\begin{array}{l}\% \text { of total } \\
\text { employment }\end{array}$ & 2009 & $0.8-1.9$ & 1.9 & 1.4 & 3.0 & 2.2 & 2.9 & 3.0 & 1.6 \\
\hline $\begin{array}{l}\text { Employment in high and medium } \\
\text { high-technology manufacturing }\end{array}$ & $\begin{array}{l}\% \text { of total } \\
\text { employment }\end{array}$ & 2008 & $3.4-6.9$ & 4.8 & 2.0 & 9.7 & 8.9 & 4.6 & 9.4 & 3.5 \\
\hline $\begin{array}{l}\text { Employment in knowledge } \\
\text { intensive services }\end{array}$ & $\begin{array}{l}\% \text { of total } \\
\text { employment }\end{array}$ & 2008 & $26-42$ & 28.9 & 26.9 & 31.0 & 29.8 & 40.0 & 26.3 & 24.1 \\
\hline PCT patent applications & $\begin{array}{l}\text { Per million } \\
\text { inhabitants }\end{array}$ & 2010 & $9-113$ & 38.4 & 21.8 & 63.0 & 65.4 & 63.7 & 110.3 & 37.4 \\
\hline Gross value added per worker & Thousand USD 3 & 2010 & $49.9-64.7$ & 60.0 & 54.8 & 70.0 & 62.7 & 64.7 & 64.4 & 58.5 \\
\hline
\end{tabular}

1. R\&D: research and development, PCT: Patent Co-operation Treaty. A number in bold indicates the region with the highest level for that indicator.

2. Based on available data so coverage may vary across indicators.

3. Constant prices and purchasing power parities.

Source: OECD (2013), OECD Regional Statistics (database).

Despite progress in building the science base, the overall innovation system remains underdeveloped relative to the OECD average and large country peers in Europe and there is limited cooperation between research entities and the business sector. Total spending on R\&D was only $1.4 \%$ of GDP in 2010 compared with an average $2.4 \%$ in the OECD, and also below the level that would be expected given Spain's GDP per capita. This is due to lower business R\&D spending, which amounted to only $0.7 \%$ of GDP in 2010 compared with an OECD average of $1.6 \%$. This contributes to under-investment in accumulating innovative assets that would under-pin sustainable productivity and GDP growth. As a result, investment in knowledge based capital $(\mathrm{KBC})$, a broad measure including computerised information, innovative intellectual property and economic competencies, is the second lowest of the 18 OECD countries for which data are available (Figure 6). To lift the contribution of innovation and knowledge based capital to productivity, economic growth and wellbeing in Spain requires tackling two inter-related challenges: increasing the capacity and quality of the research base and lifting the impact of innovation on the economy. 
Figure 6. Investment in knowledge based capital ${ }^{1}$

Per cent of market sector value added, 2010

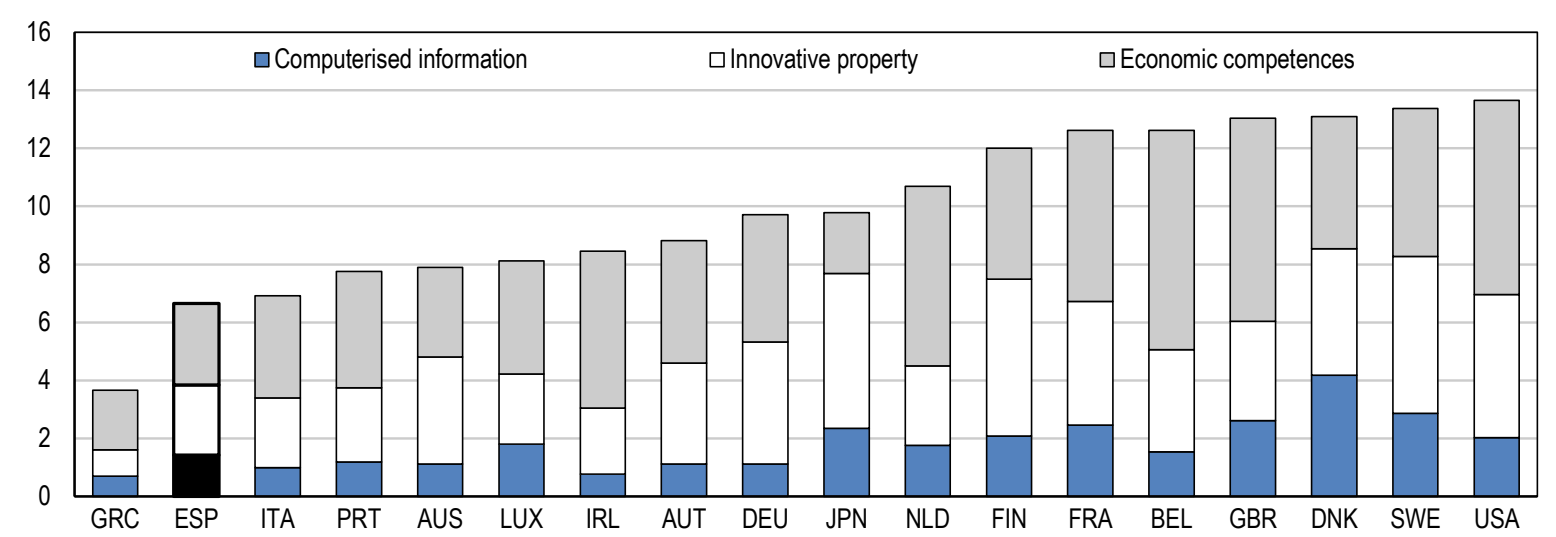

1. Computerised information covers software and databases; innovative property covers patents, copyrights, designs and trademarks; economic competencies includes brand equity, firm-specific human capital, networks of people and institutions, and organisational know-how that increases enterprise efficiency. Data refer to the market economy unless otherwise stated, which excludes real estate, public administration, health and education. Figures for the United States correspond to the definition of the private sector of the national industry and production accounts (NIPA).

Source: OECD (2013), Supporting Investment in Knowledge Capital, Growth and Innovation and OECD Economic Surveys: Ireland 2013.

\section{Increasing the capacity and quality of the research base by improving the funding mix}

The government, at both central and regional levels, plays a core role in fostering the development of the research and innovation base through its funding of universities and research centres. Current government appropriations for R\&D remain below many OECD countries with more advanced innovation systems including Finland, Germany, Sweden and the United States (Figure 7). This means convergence to the innovation performance frontier will likely be slow unless public spending is extremely well allocated over time and across instruments and institutions. The impact of public spending could also be increased by reinforcing coordination between central and regional governments to avoid duplication and by leveraging business $R \& D$ investment. The government has plans to create a national innovation agency that would help achieve this but they have not been implemented yet. 
Figure 7. Government support for research

Per cent of GDP
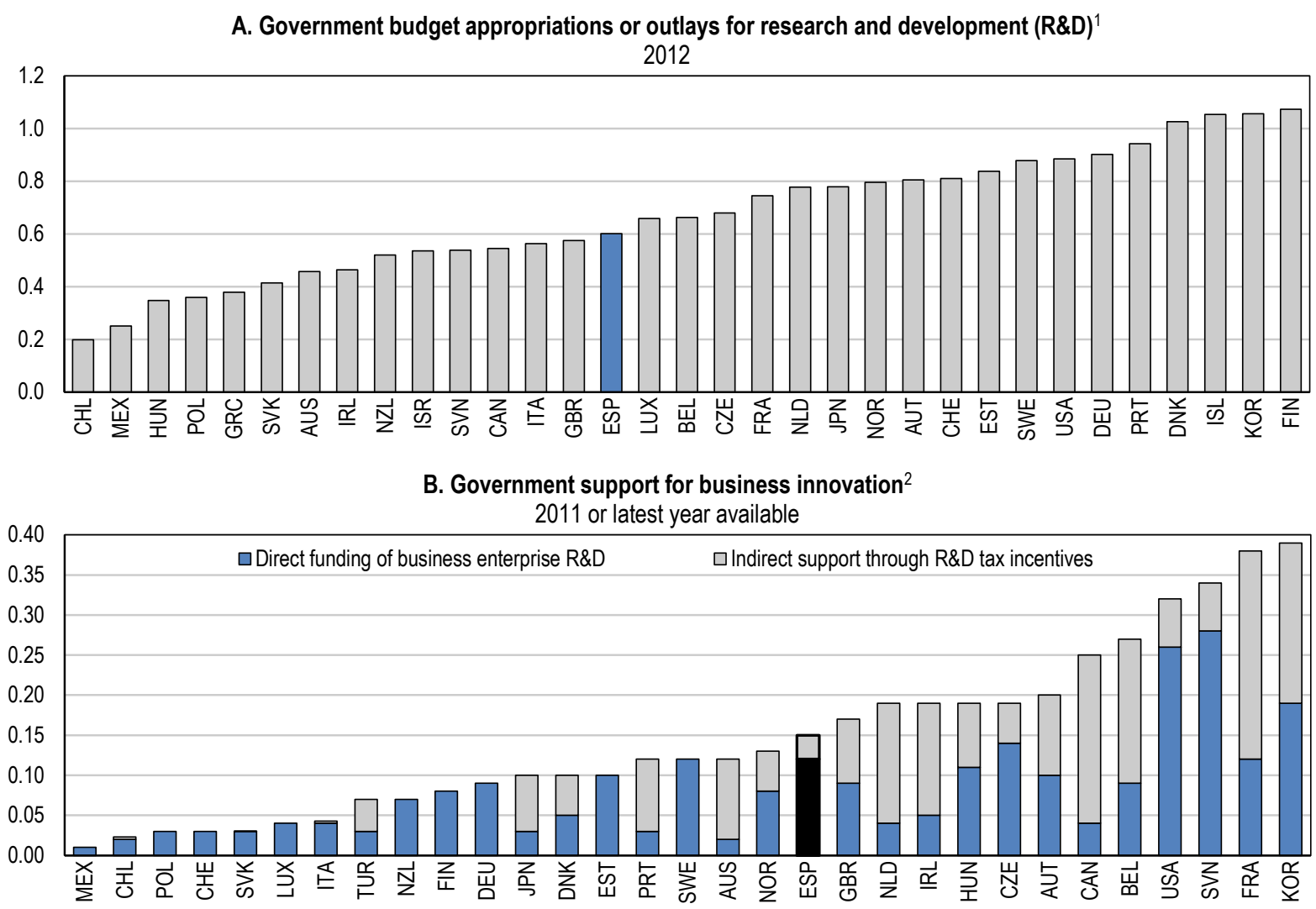

1. Measures funds committed by governments for R\&D to be carried out domestically or abroad (including by international organisations). 2011 for Canada, Chile, Korea and Mexico; 2010 for Switzerland.

2. This is an experimental indicator; international comparability may be limited. For more details see Indicator 2.11 of the $O E C D$ Science, Technology and Industry Scoreboard 2013 or www.oecd.org/sti/rd-tax-stats.htm. For Spain estimates cover 2010 and refer to the R\&D and innovation tax credit.

Source: OECD (2014), OECD Science, Technology and R\&D Statistics (database), July and OECD Science, Technology and Industry Scoreboard 2013.

General government appropriations for $\mathrm{R} \& \mathrm{D}$, including central and regional governments, as well as other innovation policies exhibit excessive volatility. Appropriations rose rapidly from 2005 to 2009, and then fell by 16\% from 2009 to 2011, as a result of public budget adjustment. The government introduced, withdrew in 2012, and approved in June 2014 the re-introduction of a similar reduction of payroll taxes associated with R\&D activities. Although potentially beneficial, especially for small or new firms with little or no taxable profit to claim ordinary R\&D tax credits, this volatility will reduce the policies' effectiveness (Guellec and van Pottelsberghe, 2003; Westmore, 2013). Investing in knowledge capital is a very different process from physical capital. The pay-offs from lifting innovation effort often take a significant time to materialise putting a premium on funding certainty to incentivise long-term investments in human capital, research programmes and networks. Sudden spending declines risk both cutting off innovation efforts before they have time to bear fruit and/or discouraging future commitments to train and research.

Recent volatility in public innovation spending, will likely slow Spain's progress towards improving innovation performance as outputs from key parts of the innovation system reduce in coming years. This is compounded by the tendency in recent years to increase the central government R\&D budget by greater use of financial credits, which require collateral or co-financing by universities and business affected by financial constraints. This has contributed to systematic underspending of budgets. 


\section{ECO/WKP(2014)68}

Central government funding of Public Research Institutions has been reduced since 2009. For example, for the Higher Council for Scientific Research (Consejo Superior de Investigaciones Cientificas, CSIC), Spain's premier public research organisation with 125 research centres across Spain and a key part of the research base, income from government budget transfers fell by around 25\% between 2009 and 2012. It was increased in 2013 and 2014, allowing CSIC to balance its budget. However, the level of central government transfers is not yet back to the 2009 level. Research staff numbers have fallen due to a strict ban on hiring replacements. Although public funding stabilised in 2013 and increased slightly in 2014, the lagged effects of previous cuts could be felt in coming years with a drop in CSIC publications and other outputs.

Previous budget cuts are also impacting on Spain's capability to attract talent internationally. Spain was able to attract a significant number of researchers, both Spanish and foreigners, who had previously published abroad and who published high quality publications as measured by citations (OECD, 2013a). This created a self-reinforcing circle of growing scientific reputation increasing the attractiveness of Spain to top-performing researchers. However, these high-performing, mobile and young researchers are not protected by permanent civil servant status and therefore are more vulnerable to staff funding cuts and also have strong opportunities outside Spain. As a result they are over-represented in staff losses associated with funding cuts. In addition, the cuts have not been based on objective performance criteria with the inherent risk that high quality work has been sacrificed. Since 2009 there are also limitations on hiring new staff, in particular only $10 \%$ of staff retiring or leaving can be replaced.

Spain's fiscal resources are stretched but the government should nevertheless try to minimise instability in spending on R\&D. A pre-requisite for ensuring this is increasing the commitment at the national level to a knowledge society by the political leadership of government, business and research sectors in Spain. It is important that there is broad political support and commitment at the highest levels of government. A possible vehicle for this would be a national level innovation network similar to Innobasque, a private non-profit innovation agency supported by government and business leaders in the Basque Country to promote cooperation between innovation actors.

Part of ensuring stability of funding should be to ensure that universities and research centres receive a minimum share of block grant funding, which is largely the responsibility of regional governments. For the university system and other research institutions the vast bulk of research funding is competition based (OECD, 2009a). This type of funding can help to encourage better performance but it needs to be complemented with sufficient block grant funding to sustain longer-term capability building research investments that under-pin shorter-term projects that would often be funded by contestable research funding.

The central government, as well as regions, also needs to allocate greater resources to solving longstanding problems in the innovation system, such as inadequate use of performance-based funding. This could be used to match one of the main challenges of the Spanish innovation system to scale-up strong research institutions.

To increase the quality of research outputs, efforts to stabilise and reallocate funding also need to be complemented by giving universities and research centres greater autonomy over and responsibility for spending and by promoting modern and flexible management practices. This should be coupled with the development of a more rigorous framework for allocating funding based on results and outcomes taking into account international peer review core principles and the inherent lags in the research process. This should include systematic external peer review.

\section{Increasing scale and specialisation}

The university system has generated a large increase in human capital with the share of tertiary qualified in Spain increasing markedly. However, its contribution to the knowledge base and knowledge transfer could be improved (OECD, 2009a). The output of scientific and engineering articles has increased but the quality remains moderate, as indicated by a ratio of highly cited science and engineering articles to total articles below the OECD median. In addition, the international ranking of Spain's universities is modest (Figure 8). 
However, there are centres of excellence within the overall university system, both highly ranked individual departments within universities of an overall more modest rank and also some universities such as the Technical University of Madrid (Universidad Politécnica de Madrid, UPM) performing strongly overall.

Figure 8. University rankings: summary

$2013 / 14$
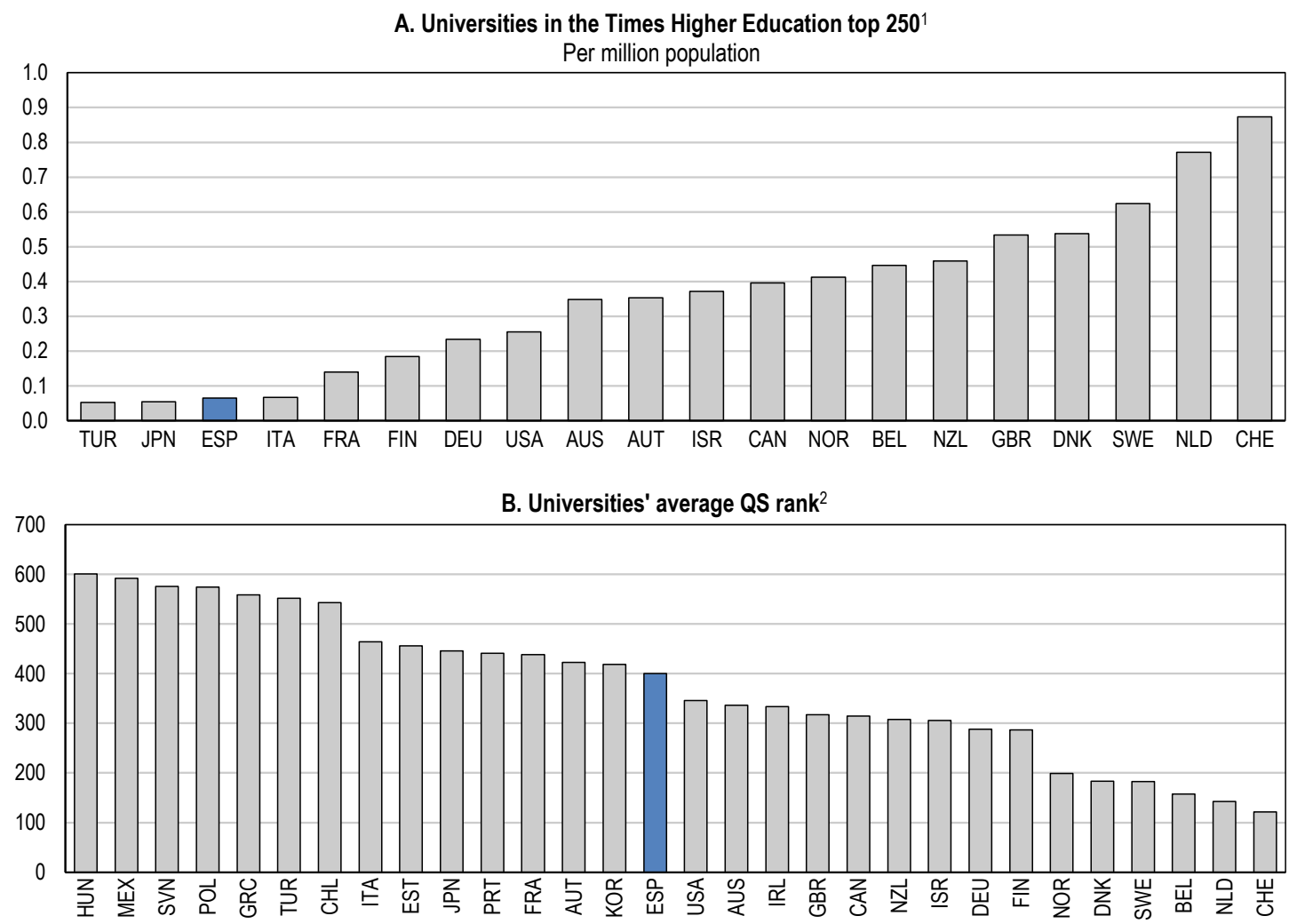

1. The ranking is based on weighted sum of 13 performance indicators of teaching, research, citations, industry income and international connections.

2. Quacquarelli Symonds' rankings of over 800 of the world's best universities. Rankings above 400 are given in ranges only so the mid-range value was applied and 701 were applied for all those given the rank $701+$.

Source: OECD calculations based on THE (2013), World University Rankings 2013-2014, Times Higher Education, www.timeshighereducation.co.uk; Quacquarelli Symonds (2013), QS World University Rankings 2013, QS Intelligence Unit, www.topuniversities.com and OECD (2013), Demography and Population Statistics (database).

High performing research based institutions in Spain have been created recently by the central government (e.g. CNIO and CNIC) and by regional governments, especially in Catalonia with more than 39 centres grouped in CERCA. Other technological centres resulted from the amalgamation or networking of smaller entities and exhibit both large scale and significant specialisation, such as Technalia and IK4. By contrast, generally universities are excessively homogenous as a result of heavy regulation leading to programme duplication and a loss of benefits from greater specialisation (OECD, 2009a). Greater information availability to students about future employability discussed below can potentially help to create demand-side pressure for specialisation as students gravitate towards degree programmes with proven employment prospects. However, the central government should also loosen regulatory requirements imposed on universities to provide such a wide variety of degree programmes at different levels.

To improve the quality of the research base and attract more outside funding, the central government should also move to actively encourage greater specialisation and scale in universities and other research institutions. In line with previous OECD recommendations (OECD, 2010a) Catalonia is already encouraging research centres to link through its SUMA programme. At the national level one tool to increase scale is to 


\section{ECO/WKP(2014)68}

expand performance based funding. This could be done by introducing new incentives and developing new tools aimed at fostering aggregation of capabilities, networking and specialisation, and by providing extra direct research funding from the central government to institutions that amalgamate, network or specialise and demonstrate a strong business case. Scale and specialisation are not only important for improving quality but also leveraging Spain's R\&D spending by attracting European Union (EU) Horizon 2020 funds. For example, UPM, a large and specialised institution was the highest ranked university in Spain and number 23 in Europe for attracting EU innovation funding during the period 2007 to 2011 from Framework Programme 7 (for innovation) (FP7), the predecessor to Horizon 2020. As well as providing funding, a "centre of research excellence" designation by the central government can help universities and other institutions to attract greater private and international funding. To preserve this advantage the central government should be highly selective, a possible benchmark could be that the institution is or has strong potential to be recognised and compete at a European level.

An expanded use of performance based funding could also be used to increase scale in research centre networks and research technology organisations (RTOs), and regional cooperation across Spain starting by building on existing higher performing organisations. Spain's regionalisation of innovation policy is both a challenge and opportunity. The potential to generate new approaches to innovation is high but then the challenge is to expand high performing institutions including across the nation. For example, the central government could further foster the expansion of better performing research organisations across Spain by providing extra direct funding to research centres that join high performing institutions such as CSIC, Technalia, IK4 or CERCA. This may also help to give the groups a national level designation and increase regional cooperation. Similarly to universities, larger research groups have the advantage of being able to attract EU innovation funds with CSIC, Technalia and IK4 all having been instrumental in attracting these funds to Spain in FP7.

\section{Improving human resources management and university governance}

The contribution of universities as well as the largest public research organisation, CSIC, to the knowledge base is also hamstrung by the civil servant status of academic staff, antiquated human resources practices and university governance. Recruitment of academic staff hired as a civil servant is lengthy and their recruitment, promotion and compensation are subject to both heavy central and regional regulation. Although in theory it is possible for academics to freely transfer between institutions and regions, in practice there is a strong home institution hiring bias and very little mobility. University governance is largely in the hands of academics democratically elected for temporary periods rather than professional managers, from an academic background or otherwise, with the incentives and autonomy to meet performance targets. This has led to inward looking institutions (OECD, 2009a). Partly in response to these problems Catalonia has shifted research capability to publicly-owned research centres that have autonomy over human resources to avoid rigidities in the university system. Catalonia has also ceased to hire university staff as civil servants, and instead using ordinary permanent labour contracts, but there is a nationally imposed maximum ceiling of $49 \%$ on the share of staff that can be hired in this way. The central government should increase this ceiling to facilitate hiring on contracts with better matching of incentives and performance goals than heavily regulated civil servant contracts allow. In addition, senior university management elected by staff and students from amongst university staff should be replaced with management selected using modern recruitment practices. Research staff in universities and at the CSIC also need greater incentives to participate in knowledge transfer and more particularly commercialisation activities as discussed below.

\section{Improving the impact of research and innovation on the economy}

Signs of a relatively restricted impact of research and innovation on the economy include low patenting rates, limited absorption of foreign technology as indicated by licence royalties, a small share of firms that innovate and low aggregate spending by firms on R\&D, principally because of lower than OECD average spending by large firms. This share is one of the smallest in the OECD and is not because of the low share of large firms in the economy but because they spend a small share of their turnover on R\&D by international 
standards. In aggregate small firm spending on R\&D is around the OECD average, although it appears to be highly concentrated as the percentage of small firms that innovate is below average (Figure 9).

Figure 9. Innovation rates by firm size

Per cent of firms that innovate, $2010^{1}$
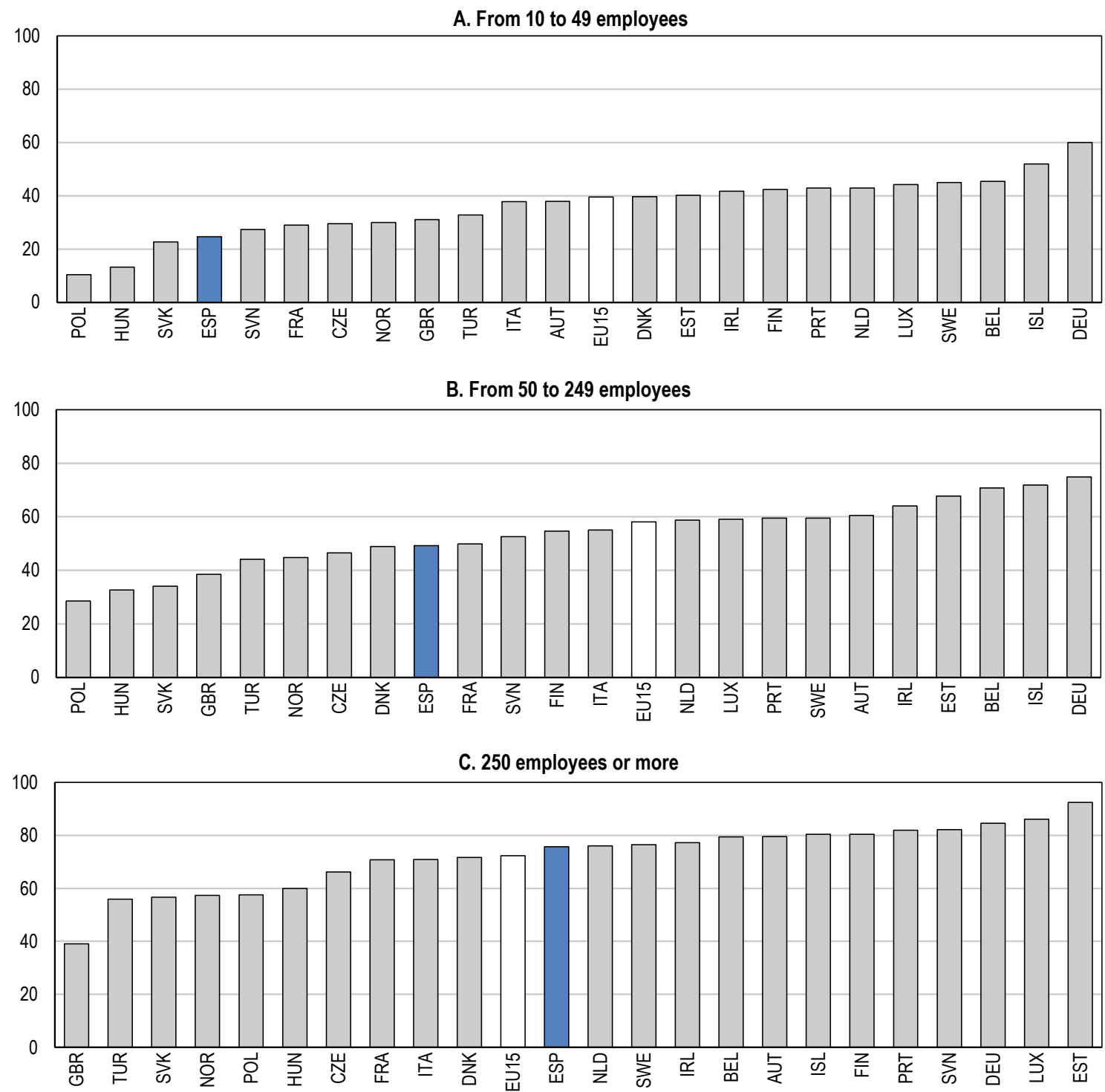

1. Product and/or process innovative firms, regardless of organisational or marketing innovation (including firms with abandoned/suspended or on-going innovation activities).

Source: Eurostat (2013), "Results of the Community Innovation Survey 2010”, Eurostat Database.

Overall government support for business innovation is around the OECD median with a mixture of direct support and $R \& D$ tax credits but business $R \& D$ is below the median, suggesting that support may not be working effectively to stimulate business R\&D. Both direct support and tax incentives provide a potentially powerful lever to improve innovation and productivity in Spain. Empirical research suggests that both support types increase business $R \& D$ and that increasing business $R \& D$ spending boosts productivity (Westmore, 2013). However, policy design is crucial. The government should maintain its mix of R\&D tax incentives and selective direct funding to firms (Andrews and Criscuolo, 2013), as each has strengths and weaknesses and their impact may vary across different types of firms (OECD, 2013b). Empirical results about whether direct support or R\&D tax credits have a stronger multiplier effect on R\&D spending and therefore productivity are 


\section{ECO/WKP(2014)68}

mixed (Haegland and Moen, 2007; Westmore, 2013). R\&D tax credits generally require fewer administrative resources to operate than direct grants. However, they appear to protect incumbents to the detriment of new entrants (Bravo-Biosca et al., 2013) and can be used as tax shelters, especially via cross-border tax planning by multinational companies (OECD, 2013c). By contrast, direct support makes small and medium-sized enterprises (SMEs) more likely to carry out R\&D to smaller firms (Czarnitski and Ebersberger, 2010). Indeed, even if R\&D tax incentives contain carry-over provisions and refunds (as they do in Spain), young firms may not fully benefit from the schemes if they lack upfront funds to start an innovative project, and in these cases public funding may be more beneficial (Busom et al., 2012).

Spain already has one of the most a priori generous R\&D tax credits in the OECD as measured by the implied effective subsidy it provides (Figure 10). It is a hybrid volume-based, incremental R\&D scheme (OECD, 2013b), which has the advantage of maintaining the level of R\&D as well as rewarding high growth of R\&D (Criscuolo, et al. 2009). However, it is not widely used, particularly by smaller firms, and business $R \& D$ remains low, suggesting it is not effective. The government should also carry out a full review of the credit to improve its effectiveness in stimulating new R\&D.

Figure 10. Tax subsidy rates on research and development expenditure

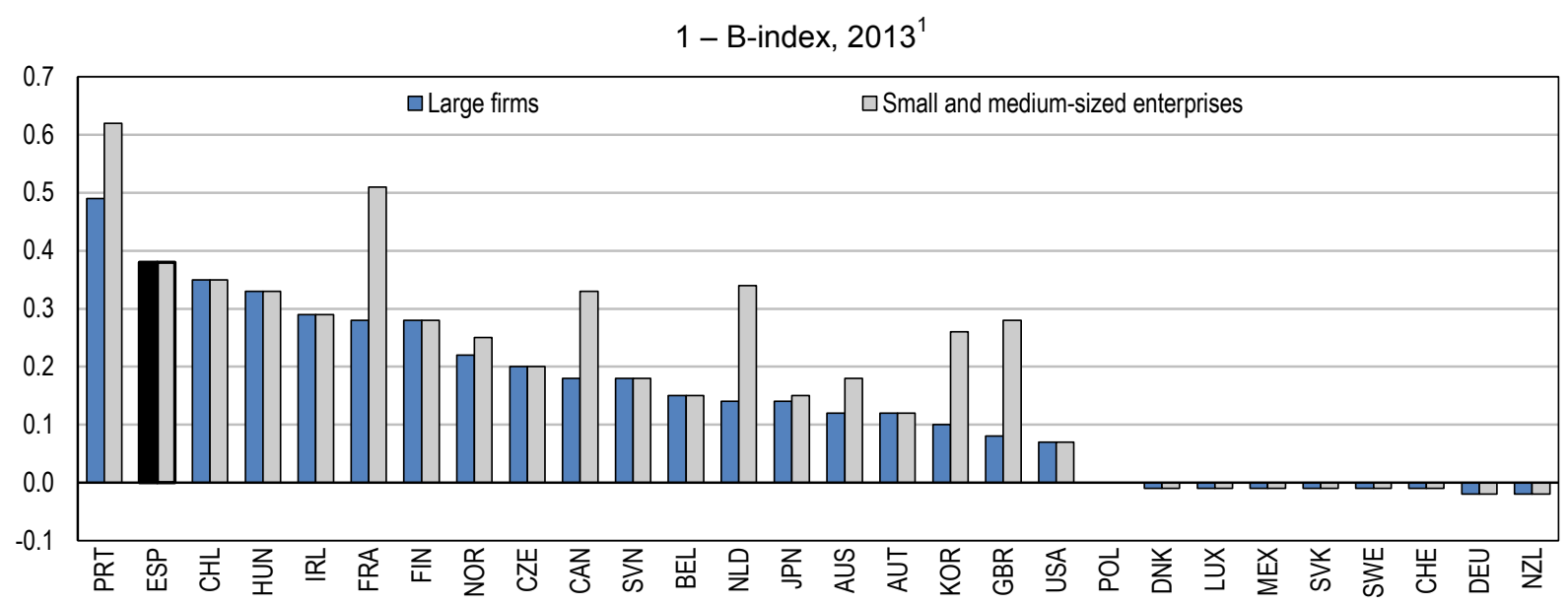

1. The B-index is a measure of the level of pre-tax profit a "representative" company needs to generate to break even on a marginal, unitary outlay on research and development (R\&D), taking into account provisions in the tax system that allow for special treatment of R\&D expenditures. Here the tax subsidy (1 - B-index) is calculated for profitable firms able to claim tax credits/allowances. International comparability may be limited, for more information see www.oecd.org/sti/rd-tax-stats.htm.

Source: OECD (2013), Science, Technology and Industry Scoreboard 2013.

A number of rigidities could discourage use of the credit, including a ceiling on the credit amount that can be claimed and employment number requirements to claim the credit. R\&D tax credits have been limited to a maximum of $60 \%$ of corporate income tax payable, which is a binding constraint, especially for smaller and newer companies with low profits. In September 2013 the government amended the scheme to allow, subject to research and employment conditions, claims up to EUR 3 million without any limit imposed by corporate tax liability. Another potential problem is that firms are required to apply for certification from the government to claim the credit. This appears to be too cumbersome and uncertain and also administratively costly. The authorities should streamline the certification process. Excessive auditing by the tax authority, or the perception of this by firms, could also be behind the low take-up rate. An evaluation of the credit should involve an independent assessment of current auditing practices and firm experiences. The evaluation of the effectiveness of the R\&D credit should ideally be done using statistical methods that generate control groups to isolate the effect of the credit beyond other factors (OECD, 2010b). The evaluation requires matching micro data on firms claiming the credit from the business register with firm level tax data held by the revenue authority. In the meantime, the government could work more closely with larger research and development and innovation organisations to help propagate the use of the R\&D tax credit among firms. 
Beyond direct financial support to business R\&D an important channel for raising the impact of the research base on the economy is to increase knowledge transfer, which will raise the share of firms that innovate as well as firm spending on R\&D. An important challenge is to increase the number and quality of linkages between firms and other innovation actors. The OECD's Science, Technology and Industry Scoreboard 2013 shows the share of Spanish firms of all size classes that cooperate on innovation with outside partners including international ones and higher education institutions is low. The weakness in higher education business linkages appears to be due to linkages being too narrowly concentrated. A partial indicator of linkages, the share of business funding of the higher education research sector is above the OECD average but fell a little from 2001 to 2011. However, the proportion of both SMEs and large firms that collaborate with higher education and public research institutes is below average.

Efforts to increase the scale and specialisation of universities, research centres and Research Technology Organisations can directly help to increase knowledge transfer to the enterprise sector and establish more effective collaboration. Empirical research suggests that larger Technology Transfer Offices as well as Science Parks both increase technology transfer activities in Spain (Caldera and Debande, 2010). Larger research organisations can afford to do this including set up support divisions to handle the intellectual property rights issues associated with commercialisation. They can also set up lab-type facilities required for testing new products as part of the commercialisation process, for example the Technical Universities of Madrid and Catalonia built new centres for support of technological innovation where activities in commercialising research will be concentrated. These larger research organisations also play a key role in helping firms to access EU innovation funds and this is facilitated by greater scale.

Knowledge transfer also depends critically on the circulation of researchers between sectors and the personal networks they build, and hence it is important that there are appropriate incentives to collaborate. Currently university and CSIC researcher promotion and bonus pay prospects depend almost exclusively on the quantity of scientific papers produced in six-year periods. Very little weight is given to knowledge transfer activities such as generating patents and spin-off companies. A second researcher progression track should be established at both universities and CSIC where knowledge transfer type activities, broadly defined and beyond simple quantitative outputs such as patents, would count heavily for promotion and pay. This requires giving more autonomy to universities and research centres to allow them to design and implement such career tracks.

Partially reflecting the industrial structure, Spain also exhibits a lower share of researchers in the business sector than the OECD average (OECD, 2013d). Part of the knowledge transfer track should be to establish a formal procedure for research staff to spend sabbatical periods in the enterprise sector. Governments at both the regional and central government level can foster these human resources practices by providing extra research funding to universities that implement them. Graduate student placements can also play important role in knowledge transfer partly by helping to build firm capacity to absorb innovation, which is a key barrier to increasing SME innovation rates. Following previous OECD recommendations (OECD, 2010a and 2011b) both the Basque Country and Catalonia have introduced pilot industrial doctorate (PhD) programmes. The central government is also launching an industrial $\mathrm{PhD}$ programme and it should work with the regions to spread best practice for industrial $\mathrm{PhD}$ programmes across Spain.

Tailoring policy supports to enterprise needs can also play a role in increasing knowledge transfer to the business sector. To meet the challenge of increasing innovation among SMEs, the Basque country has developed a risk-sharing programme, where SMEs take only a partial share in innovation projects, reducing their risk and therefore making it more financially possible for them to participate. The central government's Centre for Technological and Industrial development (Centro para el Desarollo Tecnológico Industrial, CDTI) Innodemanda programme allocates grants to firms to supply innovative solutions to meet public procurement needs, is another potential mechanism to expand the pool of innovating SMEs. Public procurement programmes carry the risk of crowding out of private-financed R\&D (Wallsten, 2000). To maximise the chance of success the government should focus procurement on areas such as healthcare where the government is the largest or only buyer and also has sufficient experience to effectively procure solutions. 


\section{ECO/WKP(2014)68}

Beyond innovation specific policies increasing the impact of innovation on the economy crucially depends on establishing a business environment where entrepreneurship, competition and innovation can flourish (Gonzalez Pandiella, 2014).

\section{Greening growth}

Putting environmental considerations more at the centre of economic policy making should be an integral part of Spain's strategy to improve medium-term sustainable growth. This can pay double dividends for living standards in Spain and can help improve the physical environment. It can also help to green Spain's technological base and thereby increase the resilience of the economy to fossil fuel price shocks as well as generating greater productivity, sales and jobs. Spain's overall policy mix is moving in this direction and since 2000 Spain has reduced the emissions intensity of the economy and is an above median performer in this domain (Table 2).

Table 2. Green growth and policy levers overview

\begin{tabular}{|c|c|c|c|c|c|}
\hline Indicator & Units & Year & Spain & $\begin{array}{l}\text { OECD } \\
\text { total }\end{array}$ & $\begin{array}{l}\text { Spain's rank } \\
\text { in OECD } \\
\text { (best to worst) }{ }^{1}\end{array}$ \\
\hline \multicolumn{6}{|l|}{ Performance } \\
\hline \multicolumn{6}{|l|}{ Climate change/Air quality } \\
\hline \multicolumn{6}{|l|}{ Production-based carbon dioxide $\left(\mathrm{CO}_{2}\right)$} \\
\hline \multirow[t]{2}{*}{ Productivity } & USD per kg of $\mathrm{CO}_{2}$ & 2001 & 3.7 & 2.5 & $9 / 34$ \\
\hline & & 2011 & 4.6 & 3.1 & $9 / 34$ \\
\hline \multirow[t]{2}{*}{ Intensity } & Tonnes per capita & 2001 & 7.0 & 10.9 & $9 / 34$ \\
\hline & & 2011 & 5.9 & 10.0 & $10 / 34$ \\
\hline \multirow[t]{2}{*}{ Emissions of sulphur oxides } & Kg per capita & 2001 & 37 & 30 & $23 / 32$ \\
\hline & & 2011 & 12 & 14 & $20 / 31$ \\
\hline \multirow[t]{2}{*}{ Emissions of nitrogen oxides } & Kg per capita & 2001 & 33 & 38 & $21 / 32$ \\
\hline & & 2011 & 22 & 25 & $19 / 31$ \\
\hline \multicolumn{6}{|l|}{ Other } \\
\hline \multirow[t]{4}{*}{$\begin{array}{l}\text { Water stress, total gross freshwater } \\
\text { abstractions }\end{array}$} & $\begin{array}{l}\% \text { of total renewable } \\
\text { resources }\end{array}$ & 2005 & 32 & 10 & $26 / 27$ \\
\hline & & 2010 & 30 & 10 & $20 / 22$ \\
\hline & Cubic metres per capita & 2005 & 822 & 880 & $21 / 28$ \\
\hline & & 2010 & 728 & 843 & $18 / 23$ \\
\hline Threatened species $^{2,3}$ & $\%$ of known species & Late 2000 s & 18 & 19 & $16 / 32$ \\
\hline \multicolumn{6}{|l|}{ Policy levers } \\
\hline \multirow[t]{2}{*}{$\begin{array}{l}\text { Public spending on environmentally- } \\
\text { related research and development }\end{array}$} & $\begin{array}{l}\% \text { of total public } \\
\text { spending }\end{array}$ & 2001 & 3.7 & 2.5 & $7 / 29$ \\
\hline & & 2011 & 4.6 & 2.7 & $4 / 31$ \\
\hline \multirow[t]{2}{*}{ Green patents ${ }^{4}$} & Index, $1990=100$ & 2000 & 664 & 367 & $6 / 22$ \\
\hline & & 2010 & 4310 & 894 & $3 / 22$ \\
\hline \multirow[t]{2}{*}{ Total environmentally-related taxes } & $\%$ of GDP & 2002 & 2.1 & 1.8 & $25 / 34$ \\
\hline & & 2012 & 1.6 & 1.6 & $28 / 34$ \\
\hline \multicolumn{6}{|c|}{$\begin{array}{l}\text { For freshwater abstractions the ranking uses the closest year of data available for a few countries where data for } 2005 \text { or } 2010 \\
\text { not available. } \\
\text { Average of shares for mammals, birds and vascular plants. } \\
\text { OECD is an unweighted average. } \\
\text { Sum of patent applications on electric and hybrid vehicles, energy efficiency in buildings and lightning, renewable energy } \\
\text { generation, air pollution abatement (from stationary sources), water pollution abatement and waste management. } 2009 \text { for the } \\
\text { OECD total. }\end{array}$} \\
\hline
\end{tabular}

Indeed, more systematically considering the environment across the policy spectrum would help to improve decision-making in areas such as buildings, energy, infrastructure and transport planning. A core tool 
for this is systematically altering charges, taxes and subsidies to change consumer and firm behaviour and thereby achieve the government's environmental/sustainable growth goals. Spain has significant potential to shift the tax burden towards environmental taxes. Spain's environmental tax revenue was $1.6 \%$ of GDP in 2012, lower than in 2002, and one of the lower shares in the OECD (Table 1.2). Even more crucially, Spain can improve the mix of charges, taxes and subsidies and in particular make more use of pricing of natural resources.

\section{Spain should move towards more equal carbon pricing}

Spain has reduced emissions intensity particularly by reducing emissions from energy industries and industry. Energy industries now account for a lower share of total emissions in Spain than the OECD average, while the share of emissions from industry, road transport and agriculture are a bit above (Figure 11). The reduction in greenhouse gas (GHG) emissions from energy industries has partly been brought about by doubling the share of renewables in electricity generation to $30 \%$ in 2010, just below its EU mandated target (Table 1.3). Despite this and the economy being in recession, Spain's total GHG emissions exceeded the target for $2008-12$ by $9 \%$.

Figure 11. Sectoral contributions to greenhouse gas emissions

Total carbon dioxide $\left(\mathrm{CO}_{2}\right)$ equivalent emissions ${ }^{1}$

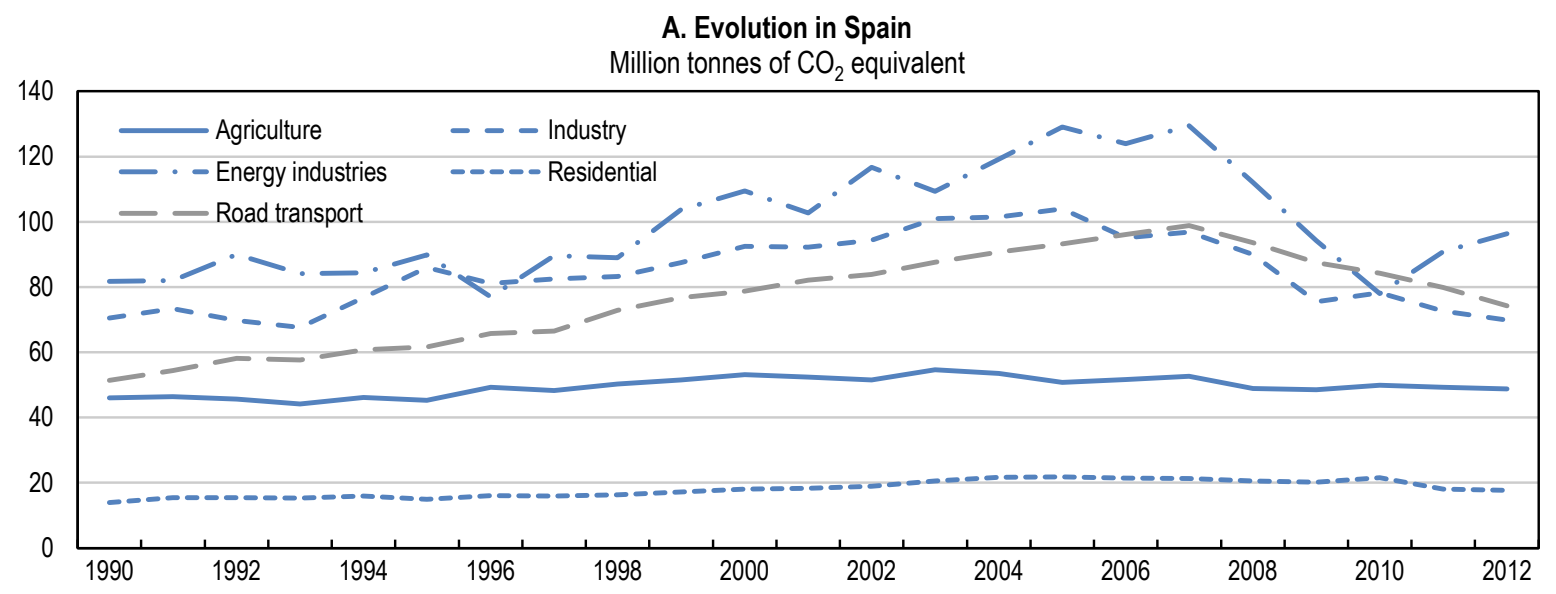

B. Shares in 2012

Spain

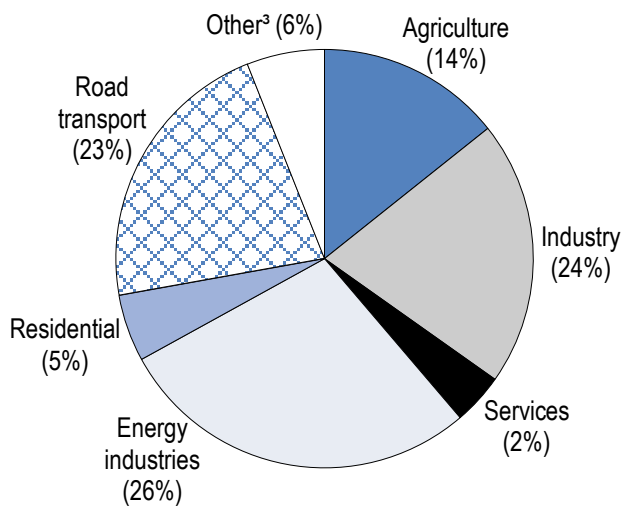

OECD ${ }^{2}$

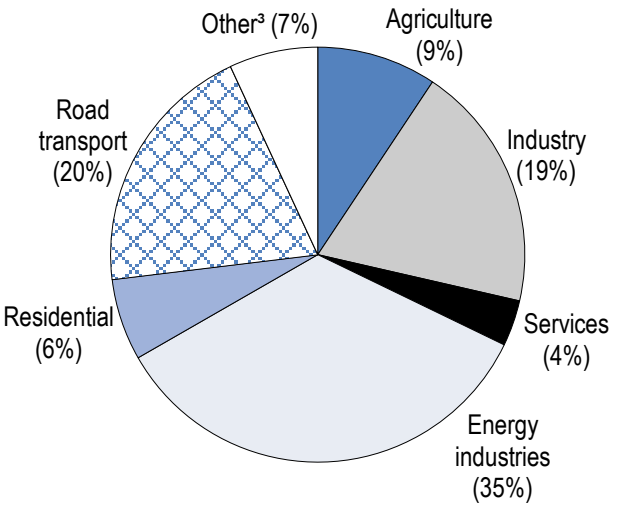

1. Excluding land use, land-use change and forestry.

2. Unweighted average excluding Chile, Israel, Korea and Mexico.

3. Includes waste; other transport; solvent and other product use; and other not elsewhere specified.

Source: UNFCCC (2014), GHG Data, United Nations Framework Convention on Climate Change, July. 
Table 3. Climate change scorecard

Greenhouse gas emissions, thousand tons of carbon dioxide $\left(\mathrm{CO}_{2}\right)$ equivalent ${ }^{1}$

\begin{tabular}{|c|c|c|c|}
\hline & Year & Actual & Target \\
\hline \multirow[t]{4}{*}{ Total greenhouse gas emissions } & 1990 & 282789 & . \\
\hline & 2000 & 378776 & $\ldots$ \\
\hline & $2008-12$ & 361400 & 333239 \\
\hline & 2020 & $\cdots$ & $\begin{array}{l}\text { Single EU-wide cap of } 20 \% \\
\text { below } 1990 \text { emissions }\end{array}$ \\
\hline \multirow[t]{2}{*}{ Emissions Trading System (ETS) } & $2008-12$ & $138100^{3}$ & \\
\hline & $2013-20$ & 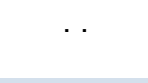 & $\begin{array}{c}\text { Single EU-wide cap of } 21 \% \\
\text { below } 2005 \text { emissions }\end{array}$ \\
\hline \multirow[t]{2}{*}{ Non ETS greenhouse gas emissions } & $2008-12$ & 223300 & \\
\hline & 2020 & $\ldots$ & $10 \%$ below 2005 emissions \\
\hline Non ETS EU annual emissions allocation (AEA) target & 2020 & & 215500 \\
\hline \multirow[t]{4}{*}{ Renewable electricity ( $\%$ of total electricity generation) } & 1990 & 17.2 & . \\
\hline & 2000 & 15.6 & $\ldots$ \\
\hline & $2012^{4}$ & 29.5 & 31.2 \\
\hline & 2020 & . & 40.0 \\
\hline Area with greatest potential to reduce emissions & . & . & Transport and buildings \\
\hline
\end{tabular}

1. Excluding land-use, change and forestry (LULUCF).

2. Equivalent to $14 \%$ below 2005 emissions.

3. Spain was assigned 152.3 million EU allowance units under the ETS.

4. Estimate for actual.

Source: European Commission (2013), "Report from the Commission to the European Parliament and The Council. Progress Towards Achieving the Kyoto and EU 2020 Objectives", Commission Staff Working Document, SWD(2013) 410 final and "Commission Decision of 26th March 2013 on Determining Member States' Annual Emission Allocations for the Period from 2013 to 2020"; IEA (2013), Renewables Information 2013, International Energy Agency; and Government of Spain (2010), Spain's National Renewable Energy Action Plan.

Around $40 \%$ of GHG emissions are regulated by the EU's Emissions Trading System (ETS) scheme, including those related to energy generation and production as well as emissions intensive industries such as oil refining, cement, pulp and paper. For the period 2013-20 the EU has a single EU wide cap for ETS emissions to be $21 \%$ below their 2005 level but there is no country cap. The ETS is a potentially efficient and relatively low cost mechanism for reducing emissions (Duval, 2008; OECD, 2013e). There is evidence that the ETS was effective in inducing energy efficiency increasing technological change in the period 2007 to 2010 (Petrick and Wagner, 2014). In the past, in part due to the economic recession, the supply of allowances was excessive leading to very low carbon prices (Lawson, 2010; Radziwill, 2012). However, in early 2014 the emissions allowance price had increased significantly due to the EU back-loading initiative to delay the auctioning of additional permits.

Spain like other EU countries also has a separate EU mandated target for the share of renewables in gross final energy consumption and needs to increase this share to meet its 2020 target. In the past Spain made heavy use of feed-in tariffs (i.e. premiums over the market price paid to renewable producers) and from 2004 feed-in premiums (guaranteed mark-ups over the market price) to encourage renewables installation. This has helped to sharply increase the share of renewables in total electricity production and Spain's actual ETS emissions were below target for 2008-12. However, the cost of this scheme to Spain per tonne of carbon emissions abated is estimated at EUR 193-225 compared with an abatement cost of under EUR 20 per tonne for reducing emissions via the ETS in Denmark, France, Germany and the United Kingdom (OECD, 2013e). The scheme also had high information requirements as it is necessary to determine what reasonable cost and return on renewables investments should be. 
Renewables technologies (both photovoltaic and wind) have become more cost-competitive over time and the government has now cancelled feed-in tariffs for new projects. New regulations that aim to ensure reasonable profitability for producers were introduced in mid-2014. With a cap and trade system in place, the most efficient policy lever to create higher EU wide incentives to reduce GHG emissions is to reduce the supply of emissions allowances and thereby increase the carbon price and incentive to innovate (Braathen, 2011). For example, if Spain increases feed-in tariffs and this induces more renewables production in Spain, this will reduce demand for ETS allowances, reduce their price and induce greater emissions in other countries. Depending on the ETS price and developments in the costs of renewables, Spain may need to introduce other policy measures to meet its renewable targets. The costs of such measures should be fully passed onto consumers and minimise fiscal costs.

For non-ETS emissions Spain is already preparing a roadmap in order to comply with its target for 2020 . However, with growth returning there will likely be upward pressure in non-ETS emissions, which include those from the agriculture, residential, transport and less energy intensive parts of the manufacturing sector. Currently a mixture of subsidies, taxes and regulations is used to mitigate emissions in these sectors. These include subsidy programmes, CLIMA (projects to reduce emissions across a variety of production sectors) where the government buys carbon dioxide $\left(\mathrm{CO}_{2}\right)$ at a fixed price of EUR 7 per ton, and PIMA (renovation projects to reduce building emissions in the tourism sector, budget EUR 400 million - PIMA-SOL; the replacement of older heavily polluting commercial vehicles as well as acquisition of motorcycles, mopeds and electrically-assisted bicycles vehicles, budget EUR 54 million - PIMA-AIRE; renewal of the "heavy duty" vehicle fleet, budget EUR 400 million - PIMA Transporte; renewal of older agricultural machinery, budget EUR 5 million - PIMA Tierra). More funds (EUR 500 million) have been devoted to the PIVE 1-5 car scrappage schemes operating from 2012-14. These provide a subsidy to encourage the replacement of older cars with new, less polluting vehicles. The government should coordinate these schemes in order to ensure that it is achieving emissions abatement at least cost and reallocate funding accordingly.

For residential buildings the Ministry of Infrastructure and Housing provides subsidies for renovations aimed at increasing energy efficiency. It is targeted at multi-property buildings ( $90 \%$ of the housing stock) and buildings constructed prior to $1980(60 \%$ of the housing stock) when there was no energy efficiency requirements in the building code, first introduced in 1979. New energy efficiency requirements increasing stringency by about 30-40\% were introduced to the building code in 2006 and in September 2013 the code was changed again to require all new buildings to be "nearly zero energy" by 2020 in line with EU goals, i.e. the building should consume almost no more energy than is produced on-site e.g. from solar panels.

The Ministry of Agriculture, Food and the Environment has been active in developing new environmental related taxes and charges. A new tax on fluorine gases (with approximately 4000 times the heating effect of $\mathrm{CO}_{2}$ ) used in cooling devices has been imposed from 1 January 2014 to encourage the repair of equipment and reduce leakages, rather than replace the gas, which is cheap to buy. In addition, the car circulation tax is being reformed in 2014 so that it will be based on the vehicle emissions rather than engine size. In addition vehicles will be inspected every four years to see if they comply with their EU emissions norm. If the vehicle deteriorates and does not comply with its norm the owner will no longer be able to drive it.

To encourage least-cost emissions abatement the goal should be to move towards a single carbon price in Spain to avoid distortions and encourage least cost abatement, the ultimate goal should be to apply a carbon tax per ton equivalent of $\mathrm{CO}_{2}$ for all non-ETS GHG emissions regardless of source. The government can start moving towards this goal by at least partially equalising the price of GHG emissions across some taxes and charges. An important non-ETS area to tackle is fuel taxation given the large contribution the transport sector makes to overall emissions (Figure 11). In particular, as of 2013 diesel attracted a lower tax rate per litre than petrol despite the fact that using one litre of petrol emits less $\mathrm{CO}_{2}$ and other particulate pollution than diesel. The government should increase the tax per litre on diesel so that is higher than the tax per litre on petrol to ensure that the carbon price is identical for both. 


\section{ECO/WKP(2014)68}

The central government should also equalise the taxation treatment of other air pollutants across Spain. Currently some regional governments tax these pollutants. To increase the efficiency of abatement, these pollutants should be uniformly taxed across Spain by the central government.

\section{Pricing tools should play a larger role in managing water scarcity}

Around $70 \%$ of Spain has a semi-arid climate, rainfall is territorially uneven and highly volatile. Climate change is expected to exacerbate these problems resulting in more frequent droughts and lower rainfall (OECD, 2011c). Over time an extensive dam building programme has increased water abstractions per capita to one of the highest in the OECD. These abstractions are also high relative to available natural resources. In 2010 Spain had the third highest level of water stress of the 22 OECD countries with available data. There is a general consensus that the potential for expanding water supply through new large-scale hydraulic projects has been exhausted. In addition local water experts in all water basins generally do not consider extending surface water storage capacity or raising groundwater extraction as the most desirable options for coping with water scarcity (Fuentes, 2011). Desalination plants constructed as part of the previous supply expansion strategy are expensive to run and water from these plants is heavily subsidised to make it affordable for farmers.

As substantially further expanding supply is not a feasible option, better demand management will be required. Spain should make greater use of water pricing signals to help ensure water is allocated economically efficiently across competing uses and also sustainably. Research suggests that price instruments are more cost-effective than non-price conservation programmes in managing demand and need not have more adverse consequences in terms of income redistribution (Olmstead and Stavins, 2008). Household water prices are low in international comparison (Figure 12). There also appears to be strong potential for efficiency gains through greater pricing of water used in agriculture. The substantial variation in water productivity across crops grown using irrigation illustrates the strong potential for efficiency gains with more use of water pricing. Over $75 \%$ of crop value-added is being generated by just $9 \%$ of irrigated water, with over $40 \%$ of irrigation water being used for very low value cereal and rice crops (Fuentes, 2011).

Figure 12. Water prices

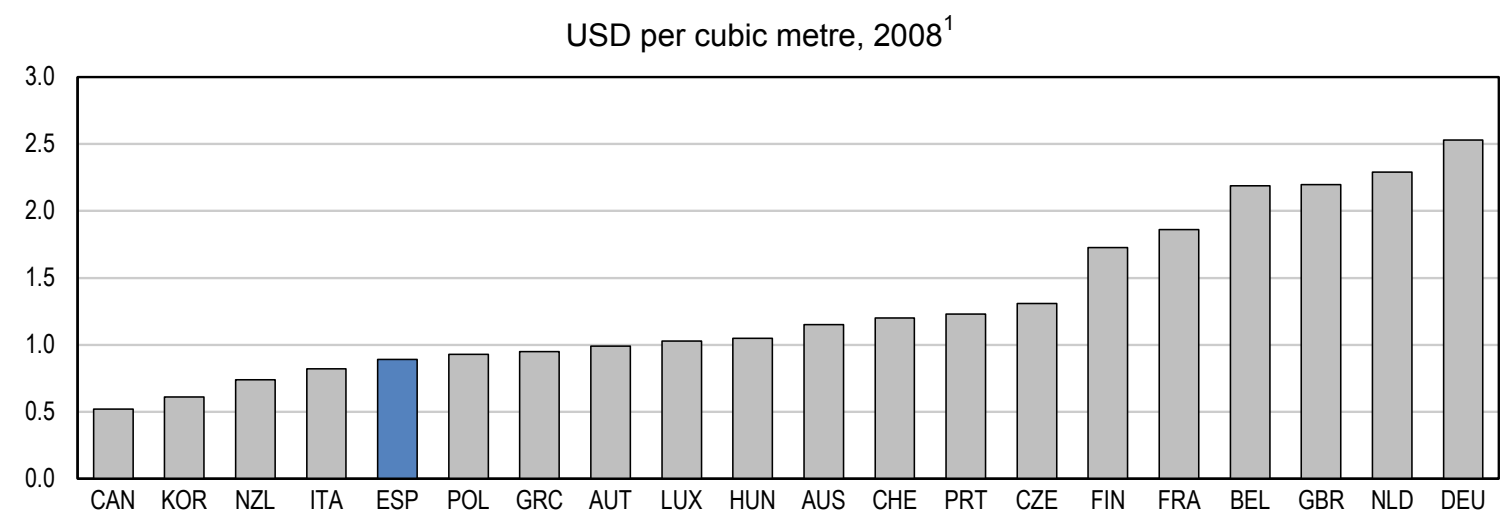

1. Unit prices including taxes. For Belgium and the United Kingdom, data shown are averages of regional data available.

Source: OECD (2010), Pricing Water Resources and Water and Sanitation Services.

In most municipalities both household and agriculture pay a water charge for infrastructure costs and this charge increases if they consume more. The exact amount of water supply costs being recovered from users is subject to debate but it is less than full marginal social cost (Fuentes, 2011). In the past even capital costs have been subsidised by EU and state funds but these will no longer be available so user charges will need to increase. The government is currently redesigning water charging policy for the capital costs of supplying water. The final policy has not been announced but it will likely involve increasing household charges, particularly in large cities, to continue the cross-subsidisation of smaller settlements. In agriculture there is already some differential charging for infrastructure. 
There are no plans to adopt charging to more fully reflect the opportunity costs (scarcity) and environmental externalities of water use in Spain. Indeed, there are both legal and governance barriers to this. By law water charging cannot exceed the capital and operating costs of supplying water and there are significant legal barriers to trading water rights - seller's cannot sell rights that were not used prior to the sale, urban users are effectively banned from selling to farmers, and water dealers and traders are banned by law (Fuentes, 2011). Spain, should remove legal restrictions to charging for scarcity and environmental externalities, as well as those on trading water rights.

As already recommended in the OECD Economic Survey 2010 the current system of allocating water rights concessions for consumptive and non-consumptive use such as electricity generation on the basis of past use should be replaced with auctioning of new concessions, as well as of concessions that expire. This would help ensure water is allocated to its most productive use and water prices reflect scarcity as required by the EU Water Framework directive. Charging for environmental and scarcity costs is complex so linkages between river basin authorities who manage water resources and academic experts in resource economics would also assist in implementing charging to cover these costs (González Gómez et al., 2012).

\section{Fostering green innovation}

Green innovation can both lift growth and improve environmental outcomes. There was a large increase in green patent applications filed by Spain from 1999-2008, especially those related to renewable, particularly solar, energy. As a result Spain had the 9th largest number of applications in the OECD in 2008, although this remained below France, the United Kingdom, and especially Germany (OECD, 2011d). Increasing green innovation depends on improving both supply and demand side policies. On the supply-side green innovation, like all innovation depends heavily on the capability and interactions of different actors in the innovation system (universities, firms, government) as well as the broader business environment. The public sector is relatively heavily involved in green innovation in Spain, with the fourth highest share of public R\&D spending on environmental related issues in the OECD (Table 1.2) and a relatively high share of green patents filed by public research organisations (OECD, 2011d). However, the links between public and private researchers, as well as commercialisation of innovative products, remains under-developed (Cochado et al., 2012). Research Technology Organisations (RTOs) can play an important role in building these linkages and bringing green technologies to the market. Part of an expanded centre of excellence programme could be to provide extra funding to RTOs specialising in linking the public and private sectors in the environmental technology area. In the interests of policy coordination, this could be done in areas where the government is through other policies, such as taxation on emissions, encouraging the use of greener technologies.

It is on the demand-side that green innovation faces particularly strong challenges as market prices often don't reflect the environmental costs and benefits of different activities and therefore provide poor incentives to innovate. Government policies can play an important role in ensuring that market prices reflect better environmental costs and benefits through such instruments as better carbon and water pricing. Such market instruments put less stress on limited fiscal resources and avoid the risk of technology capture and creation of vested interests that direct supports entail (OECD, 2011d). Such pricing signals for green innovation should be further complemented by gradually tightening regulatory standards, as the government did in September 2013 with the introduction of the nearly zero emissions building initiative by 2020 . However, to ensure maximum private sector investment, it is important that the government avoids abrupt policy changes as occurred with the feed-in tariff and premium policy. Strong and transparent signals about the future regulatory path should be set out. One of the aims of the government's recent electricity reforms is to ensure greater future and regulatory certainty. The government also has a green procurement strategy but should complement this with an evaluation programme to measure results, which is currently not the case.

\section{Increasing the returns from education}

A central part of raising productivity is further boosting education and skill levels in the working age population, while making better use of the talent that has already been accumulated. Over the past decade, the share of persons with both upper secondary education and particularly tertiary qualifications has risen 


\section{ECO/WKP(2014)68}

(Table 1.4). The level of education in the same age cohorts has also improved over time and relative to the OECD.

Table 4. Educational attainment

Per cent of population

\begin{tabular}{llccc|ccc|cccc}
\hline & & \multicolumn{3}{c|}{ Lower secondary } & \multicolumn{3}{c|}{ Upper secondary } & \multicolumn{4}{c}{ Tertiary } \\
\cline { 3 - 11 } & 2000 & 2012 & $\begin{array}{c}\text { Change } \\
2000-12^{1}\end{array}$ & 2000 & 2012 & $\begin{array}{c}\text { Change } \\
2000-12^{1}\end{array}$ & 2000 & 2012 & $\begin{array}{c}\text { Change } \\
2000-12^{1}\end{array}$ \\
\hline Age 25-64 & Spain & 62 & 45 & -16 & 16 & 22 & 7 & 23 & 32 & 10 \\
& OECD & 34 & 24 & -10 & 44 & 44 & 0 & 22 & 33 & 11 \\
Age 25-34 & Spain & 45 & 36 & -9 & 21 & 25 & 4 & 34 & 39 & 5 \\
& OECD & 24 & 17 & -7 & 49 & 44 & -6 & 26 & 40 & 13 \\
Age 55-64 & Spain & 85 & 65 & -20 & 6 & 16 & 11 & 10 & 19 & 9 \\
& OECD & 51 & 35 & -16 & 34 & 42 & 8 & 15 & 25 & 9 \\
\hline
\end{tabular}

1. Numbers may not add up exactly due to rounding.

Source: OECD (2014), Education at a Glance 2014: OECD Indicators.

Despite this overall progress, $45 \%$ of the workforce aged 25-64 had only lower secondary education or less in 2012, well above the OECD average of $24 \%$. Even in younger age cohorts the proportion was high, with $36 \%$ of even those aged between 25-34 having only lower secondary education or less, the fourth highest proportion in the OECD. Eurostat data for even younger cohorts (18-24 years old) suggests that Spain is continuing to generate a large group of poorly educated youth who have bleak employment prospects in a globalised economy. Over the past decade the share of this group with lower secondary education or less has remained over $40 \%$. Consistent with having a large share of poorly qualified labour, the recent OECD Survey of Adult Skills (PIACC) found Spain has the worst numeracy and second worst literacy skills of the 23 countries and regions surveyed. However, encouragingly there does seem to be intergenerational improvement occurring.

At the other end of the education and skills spectrum, it appears that Spain is not fully harnessing the increased pool of tertiary qualified as well as the skills already existing in the workforce. The proportion of tertiary graduates employed in jobs that typically do not require this type of qualification has been constantly higher than most of the rest of Europe over the past decade, indicating this is a structural problem (Figure 13, Panel A). Partially reflecting this, private and public net returns to tertiary education are less than OECD average in Spain. Consistent with this Spain also seems to be under utilising the skills that do exist with a high proportion of workers in occupations for which they are over-skilled (Figure 13, Panel B). 
Figure 13. Skills mismatches are high

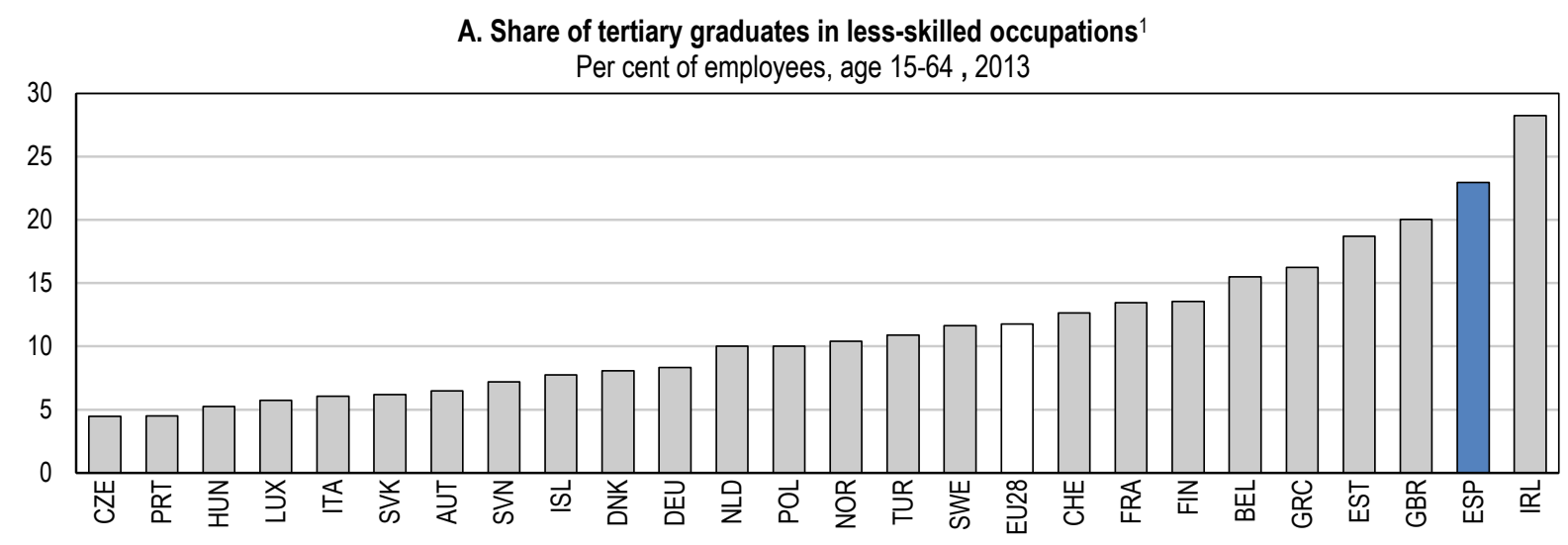

B. Skills mismatch in literacy in Spain is high

Percentage of over and under-skilled workers, $2012^{2}$

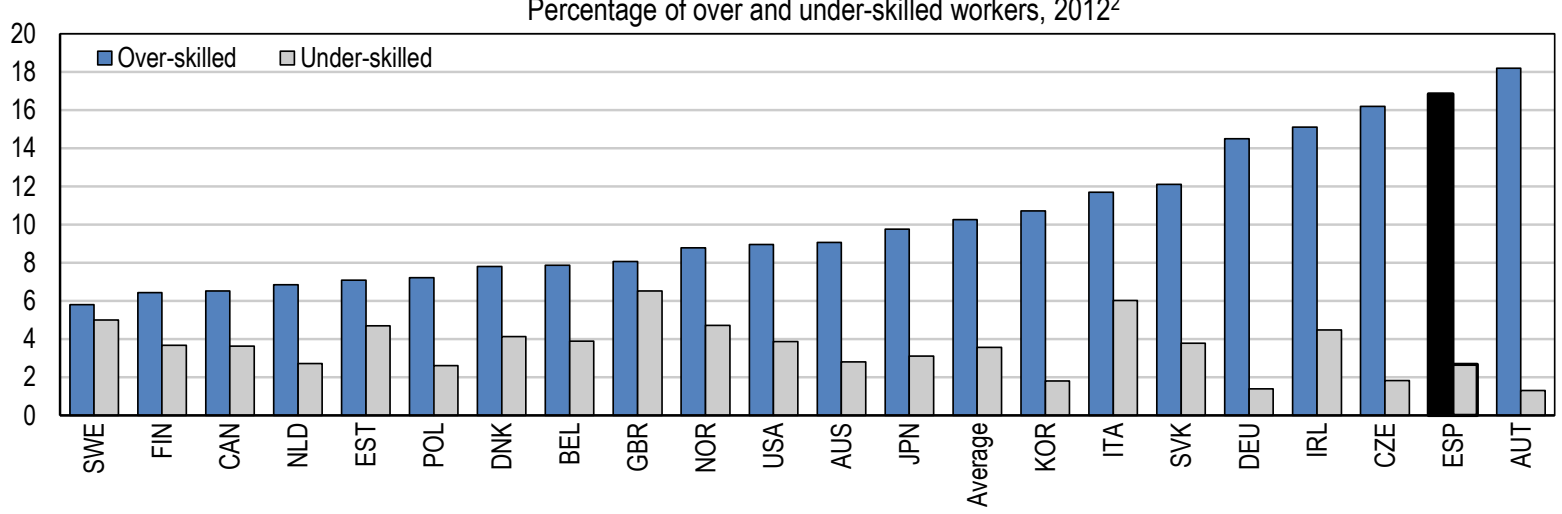

1. Share of employees with a first and second stage of tertiary education (levels 5 and 6 of ISCED, the international standard classification of education) in non-managerial, non-professional, non-technical occupations (levels 4-9 of ISCO, the international standard classification of occupations).

2. Over-skilled workers are those whose proficiency score is higher than that corresponding to the 95th percentile of self-reported well-matched workers (i.e. workers who neither feel they have the skills to perform a more demanding job nor feel the need of further training in order to be able to perform their current jobs satisfactorily) in their country and occupation. Under-skilled workers are those whose proficiency score is lower than that corresponding to the 5th percentile of self-reported well-matched workers in their country and occupation. The United Kingdom covers England and Northern Ireland only; Belgium covers Flanders.

Source: Eurostat (2014), "Population and Social Conditions", Eurostat Database, July and OECD (2013), OECD Skills Outlook 2013: First Results from the Survey of Adult Skills.

The main reason for the still large share of poorly qualified youth is that the drop-out rate from secondary school remains too high (Figure 14). This in turn appears to be associated with a cycle of poor performance, grade repetition and discouragement resulting from a relatively inflexible assessment system (Wölfl, 2013). Indeed, the average performance of Spanish secondary school students, as measured by the OECD's PISA Survey 2012, remained statistically significantly below the OECD average in mathematics, science, reading and problem solving. Pre-crisis favourable economic conditions for low-skilled workers also contributed to increased drop-out rates (Lacuesta et al., 2012). 
Figure 14. Graduation rates in upper secondary education

Per cent, $2012^{1}$

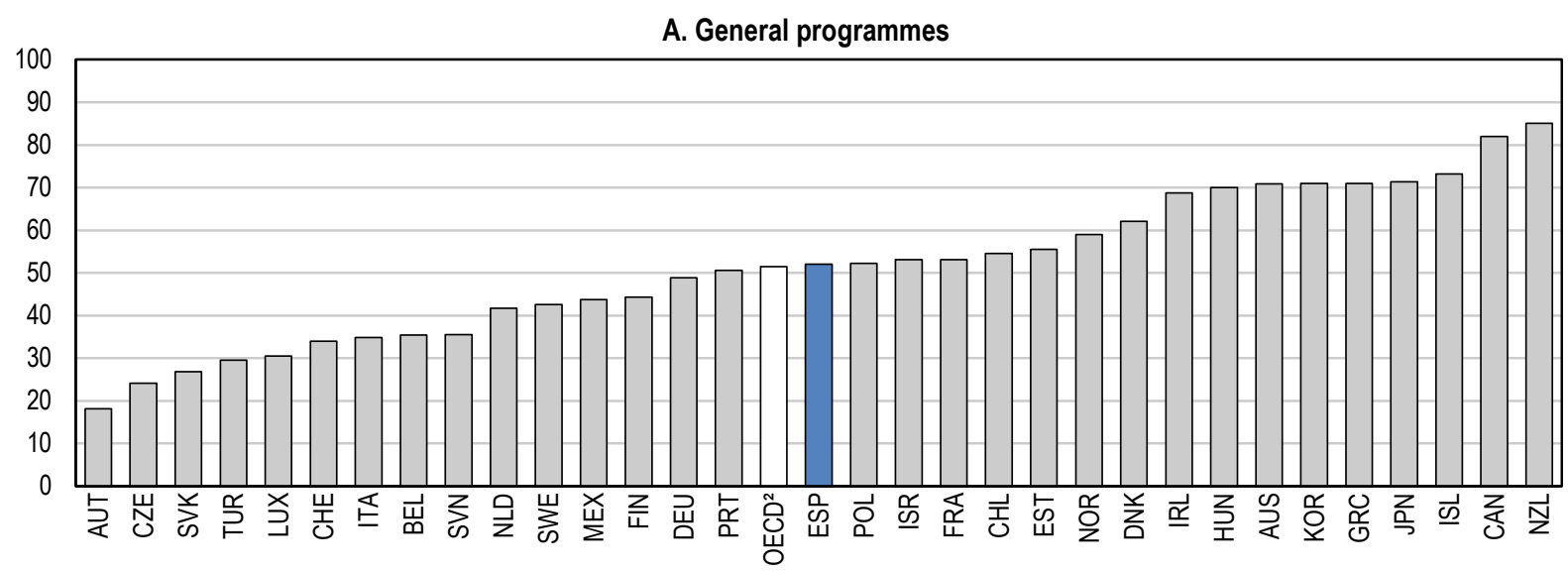

B. Vocational programmes

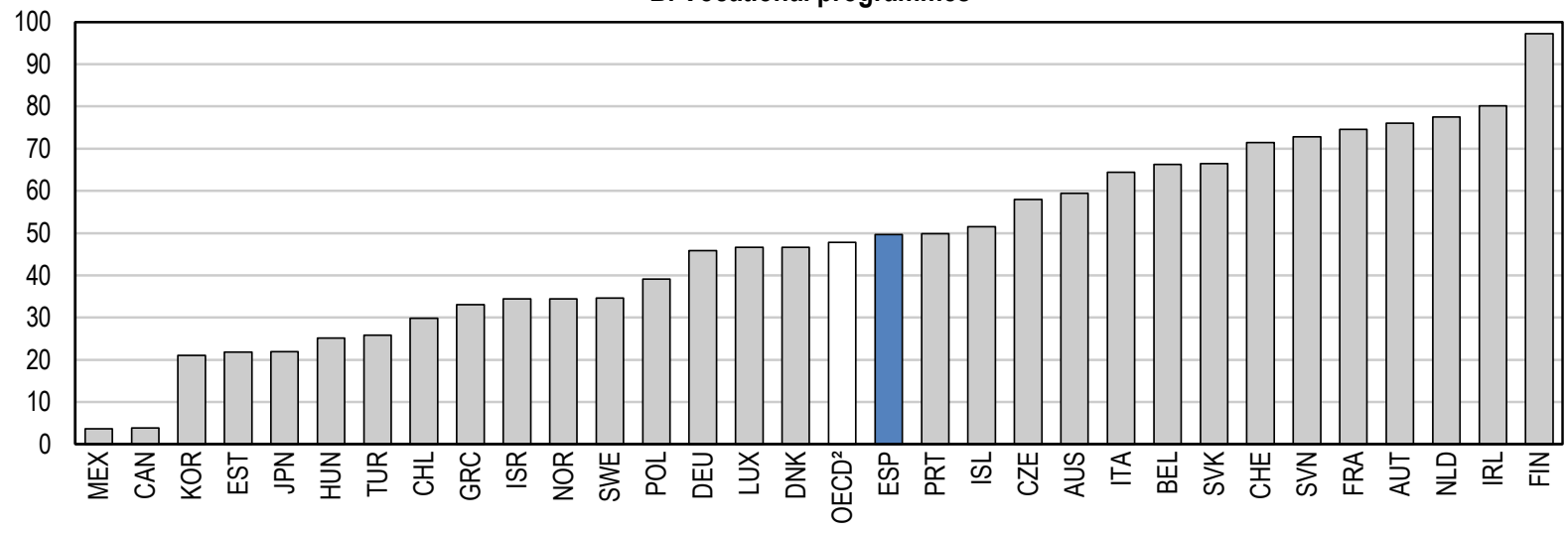

1. 2010 for Australia and Canada.

2. Average of data shown.

Source: OECD (2014), Education at a Glance 2014: OECD Indicators.

To tackle the drop-out and the associated low achievement problem requires a genuinely strengthened vocational education and training (VET) track to complement the academic one. The government in 2013 reformed the secondary education system by: radically changing the system of assessment by introducing external and standardised tests at the end of each of the education levels (primary school, compulsory secondary school and upper secondary school); increasing school level accountability and autonomy including over the curricula and materials for elective subjects and teacher appointments; lowering from 16 to 15 the age when students choose a vocational or academic track; introducing a basic initial (VET) year (Basic IVET) in the final (fourth) year of lower secondary school; increasing the practical training component of the two VET year programme at the upper secondary level (intermediate VET) from currently around $20 \%$ to a minimum of $33 \%$ up to a maximum of $75 \%$; and introducing a lifelong learning programme. Intermediate VET can be followed by tertiary non-university level VET (higher VET), the completion of which will allow direct entrance to university. The reform is scheduled for implementation at the primary level and basic VET from September 2014, and secondary, post-secondary and intermediate VET from September 2015. Previously students needed to pass all internally assessed subjects to obtain the certificate of compulsory lower secondary education (ESO) to graduate to upper secondary education. This will be replaced with a national standardised exam (of the programme for international student assessment [PISA] type), which students will be allowed to sit at the end of lower secondary schooling, providing they failed no more than two subjects and passed mathematics and Spanish. 
Experience suggests the reforms are going in the right direction. Earlier tracking of school students is controversial because it can reduce equality of opportunity but empirical evidence suggests that it does reduce drop-out rates (Felgueroso et al., 2013). Empirical evidence also suggests that standardised tests improve student performance (Hanushek and Woessmann, 2011; OECD, 2012a). The Madrid region, following the introduction of similar standardised tests at ages 7,11 and 14, experienced higher PISA performance and lower drop-out rates than it had previously, and performed better than Spain overall. Greater school autonomy and accountability, by allowing more adaptation to local needs, both improve student performance (World Bank, 2009 and 2011).

However, the enduring negative consequences for low-skilled youth of unemployment following school drop-out including lower earnings, health and life satisfaction (Scarpetta et al., 2010; Bell and Blanchflower, 2009), and the lengthy time it will take to fully implement such a large reform, argue for complementary radical action now to mitigate drop-outs. Schools should be more flexible with the requirements to move to upper secondary school education, except where it is clear the student does not have basic pre-requisites to succeed in the VET or academic tracks. This needs to be complemented with specific support for student lagging behind and at risk of drop-out. To improve equity in education the government should fully implement the components of the new law dealing with improving and raising students' achievements. This should include fully implementing a strategy for low performing and disadvantaged schools to improve and raise their students' achievement (OECD, 2012b). Part of this should be a regular evaluation of school performance in lifting student skill levels.

In 2012 the government introduced a new dual VET (simultaneous school and firm training, with $75-80 \%$ of time spent at the firm). Such a system plays an important role in Austria, Belgium, France, Switzerland and most notably Germany, where $90 \%$ of students participate in dual VET (García Perea and García Coria, 2014). As the dual system has a greater practical component and more company involvement in training design, this should help to improve the labour market relevance and employability of students. Encouragingly the training and apprenticeship labour contract reformed in 2012 had an increase of $60 \%$ yearto-year. However, it will take time to establish an extensive dual VET system. Finding firms willing and able to participate in the system will likely be challenging, especially given the prevalence of very small firms. For more immediate results the government should complement the introduction of the dual VET, by further increasing the minimum work-based component of existing intermediate VET at the upper secondary level in Spain, where around $95 \%$ of VET students are located. This should be done particularly by further increasing the time spent with companies.

The central government is also planning reforms to university education to improve efficiency in a system where $30 \%$ of degree programmes have fewer than 30 students. With some important exceptions there are relatively few highly ranked universities by international standards, and an excessive degree of homogeneity across universities (OECD, 2009b). One of the aims of the reform is to improve the relevance of university education to the labour market. A number of new tools are being designed at the central government level to help universities better plan the supply of places and to better inform students about the labour market outcomes from different degrees and institutions. On the supply side, a new accounting system will be rolled out in 2015 that will better identify the cost of providing additional places in different degrees.

On the demand side, based on the matching of graduation and social security records, in 2014 the government is making available data on the labour market outcomes of graduates in terms of labour market status and broad income band by degree and institution. Currently, demand signals appear weak with over $80 \%$ of students remaining in their home regions for their university education. Providing greater information to students is potentially an important device to encourage competition and specialisation amongst the teaching offer across universities. The presence of departments with an international reputation for quality within universities of lesser overall performance suggests that there is already a base on which to build specialisation and improve both quality and labour market relevance of degrees.

A significant challenge in this reform will be to ensure students are really aware of, and make use of, this information about transitions to labour market and employability. In order to achieve meaningful decision 


\section{ECO/WKP(2014)68}

making by students, the authorities together with schools should support and further develop an adequate career guidance system throughout the whole education system including VET. Integrated guidance provision is an important tool for helping citizens to make educational training and occupational choices. Communication efforts, such as ensuring careers guidance services at schools making information from the new employment outcomes data part of their advice tools, would be an important part of implementing this reform. The government should ensure that this information is widely communicated and the responsibility for its collection and dissemination transferred to the National Statistics Office to ensure the data remains in the public domain. The government should also complement these efforts by removing national regulatory barriers to specialisation that set a minimum on the number of degree courses and types that any University, whether public or private must offer.

\section{Better harnessing labour resources}

Better utilising labour resources is one of the main ways Spain can boost potential growth. Labour market inflexibility has been identified as one of the most important causes of low productivity growth in Spain (Mora-Sanguinetti and Fuentes, 2012). More flexible labour markets can boost medium-term growth by reducing the structural unemployment rate and boosting productivity, including by facilitating the entry of new and more dynamic firms (Gonzalez Pandiella, 2014). Spain has an unemployment rate of around 25\%, the second highest in the OECD after Greece (Figure 15). Spain's youth unemployment rate is also extremely elevated at $55 \%$ but the ratio of youth to aggregate unemployment is not exceptional, suggesting the unemployment problem is general rather than particularly a youth one. 
Figure 15. The labour market situation is difficult
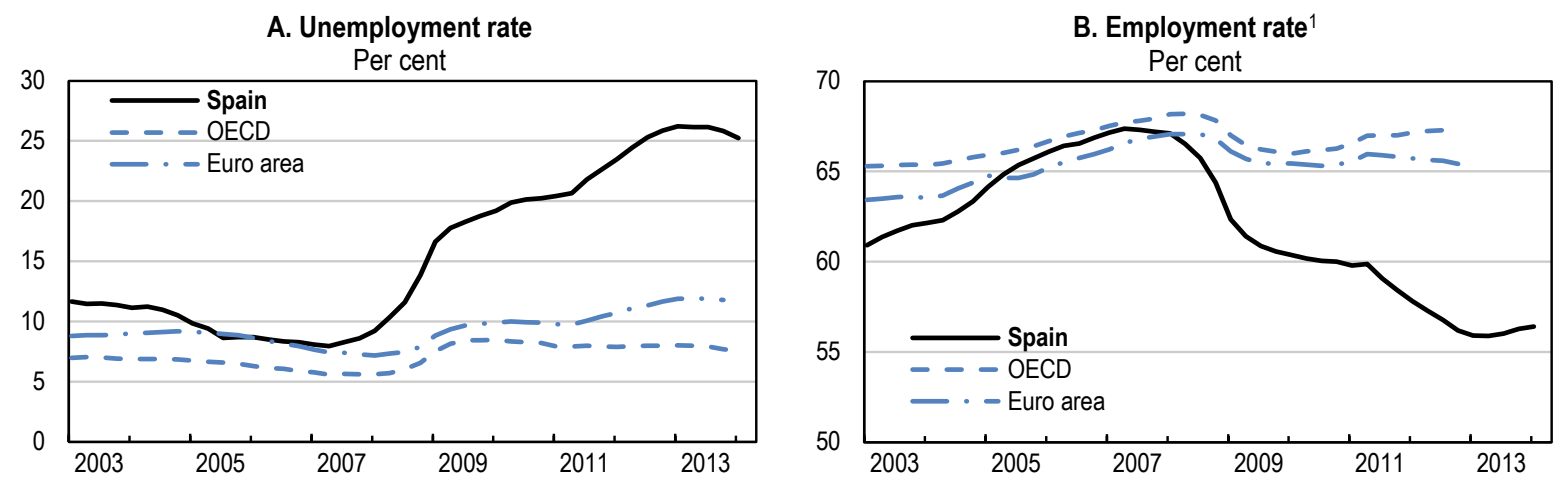

C. Long-term unemployment

Persons unemployed for more than one year in $\%$ of total unemployed ${ }^{2}$

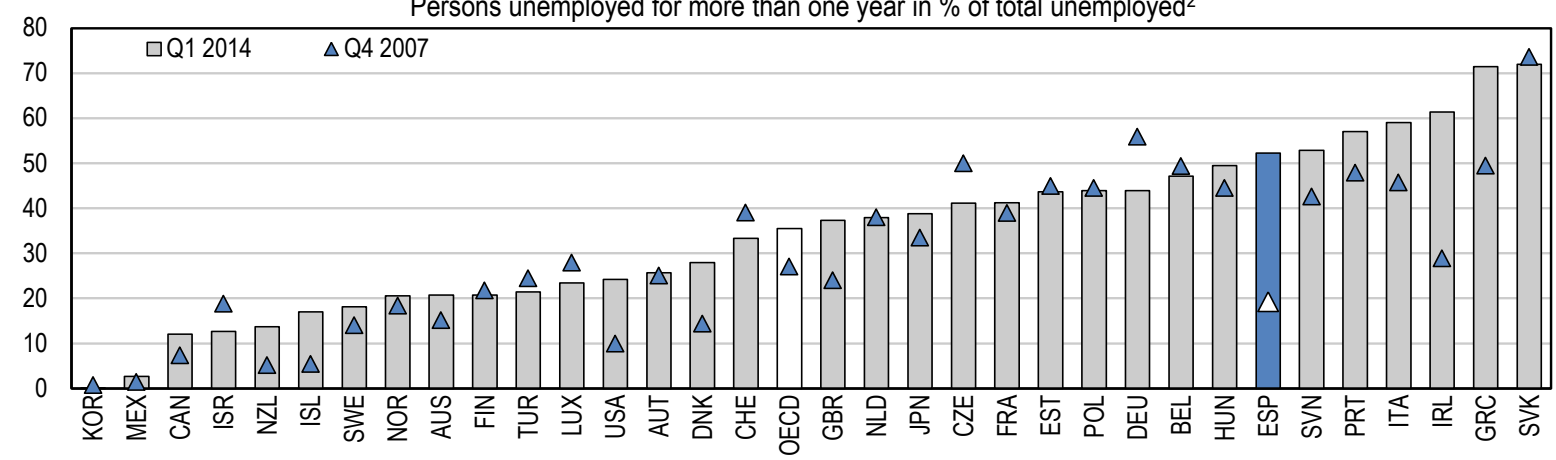

D. Ratio of youth unemployment rate to total unemployment rate ${ }^{3}$

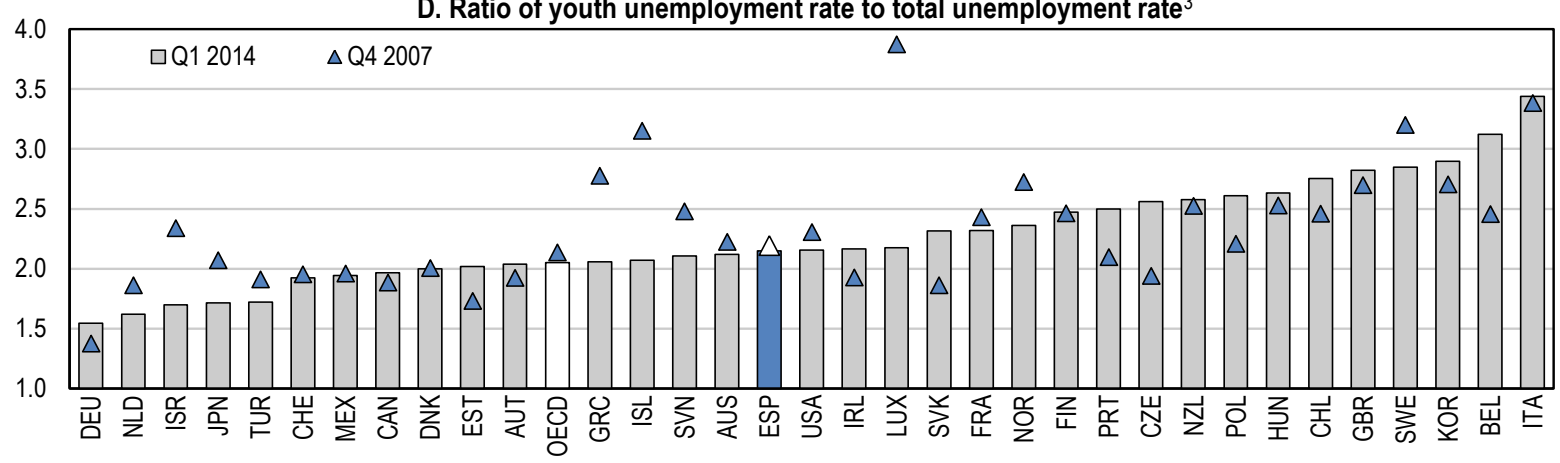

1. Employment in per cent of working-age population. The OECD aggregate is an average of the country rates.

2. Data are smoothed using three-quarter moving averages and include adjustments for breaks in series. Q4 2013 instead of Q1 2014 for Israel.

3. Instead of Q4 data for 2007 data cover Q2 for Switzerland.

Source: OECD (2014), OECD Economic Outlook: Statistics and Projections and OECD Employment and Labour Market Statistics (databases), July; and Online OECD Employment Database, July, www.oecd.org/employment/emp/onlineoecdemploymentdatabase.htm.

Property-related booms and busts tend to be associated with sharp rises in the unemployment rate $(\mathrm{OECD}, 2010 \mathrm{c})$. However, the high unemployment rate is also the legacy of structural problems, including an inadequate activation regime, insufficient responsiveness of wages to economic conditions (real wages rose during the 2008-09 recession); a high level of protection for permanent relative to temporary contracts resulting in dualism, and housing market impediments to labour mobility. As a consequence one of the main adjustment mechanisms in the face of downturns has been to fire temporary workers, rather than using other forms of adjustment such as reducing hours, further exacerbating unemployment (Figure 16). This has resulted in one of the strongest reactions of employment to activity in the OECD in Spain's double dip recession (2008-09 and 2011-13). Indeed, during the 2008-09 recession, average hours rose, while labour 


\section{ECO/WKP(2014)68}

shedding relative to the decline in GDP was so intense that productivity increased, contrary to the standard recessionary pattern when productivity normally falls (OECD, 2010c). The ratio of employment to GDP decline was stronger still in the 2011-13 recession.

Figure 16. Okun's coefficient

Peak-to-trough ratio of the decrease in employment to the decrease in GDP since $2008^{1}$

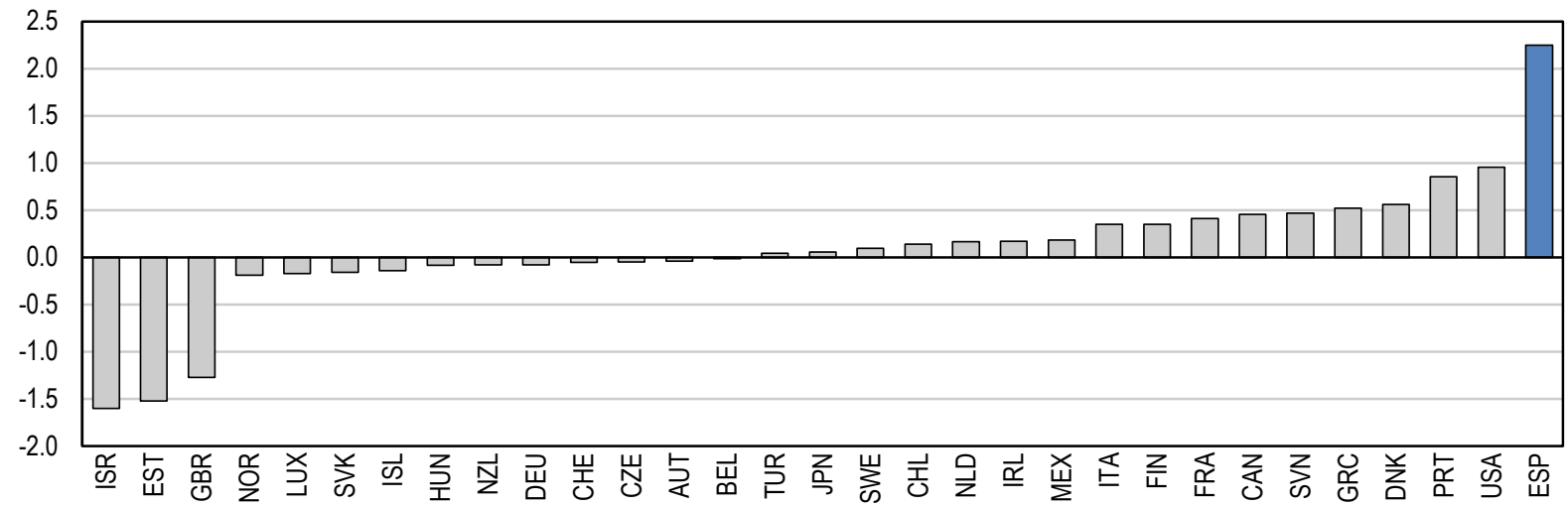

1. Ratio of the percentage point decrease in the employment rate to the percentage fall in real GDP. Average of recession ratios since 2008. Recessions are considered to occur between local peaks and troughs of real GDP (y) series in levels. A local peak (trough) occurs at time $t$ when $y_{t}>(<) y_{t \pm k}$ where $k=1,2$. The turning points are further refined by the following requirements: the peaks and troughs must alternate, each cycle must have a minimum duration of five quarters and each phase (expansion, recession) must be at least two quarters long. Australia, Korea and Poland are not considered to have experienced a recession.

Source: Calculations based on OECD (2014), "OECD Economic Outlook No. 95", OECD Economic Outlook: Statistics and Projections (database).

According to the household labour force survey, more than half of the total of nearly 6 million unemployed in Spain is long-term (over one year). Around half of total unemployed as well as youth unemployed under the age of 30 and first-time job seekers have attained only lower secondary education or less. In addition, up to $3 / 4$ million of the unemployed formerly worked in the construction industry. These groups are highly vulnerable to being structurally unemployed. They have skills that are inadequate for the types of employment that Spain will likely generate in coming years. There is a high risk that many of the unemployed will be left behind as a permanent legacy of the recession. Consequently, the most pressing labour market issue is how to deal with the huge number of unemployed people. Improving the functioning of the labour market and getting the unemployed back into work is the strongest lever the government can pull to sustainably reverse the significant rise in poverty and inequality in Spain. The long-term unemployed and low-skilled need to be activated and re-trained now so they can take advantage of the recovery as it strengthens.

\section{The activation regime is in need of a major overhaul}

Improving active labour market policies (ALMPs) is key to reducing unemployment. Reforms to ALMPs are less advanced than to employment protection, and wage bargaining and activation policy in Spain is far from the OECD's best practice. Despite being kept as a budget priority, spending on activation has increased by only $10 \%$ since 2007 despite the number of unemployed more than doubling, the public employment services have room to improve their inefficiency, and the balance of public spending is skewed towards passive measures (Figure 17). Spending on job search assistance is low by international standards with one employee of public employment service (PES) in charge of more than 250 unemployed, which is at the higher end of the range for European countries. (Table 5). 
Figure 17. Public expenditure on labour market programmes ${ }^{1}$

Per cent of GDP

$\square 2007^{2}$

$\square 2012^{3}$
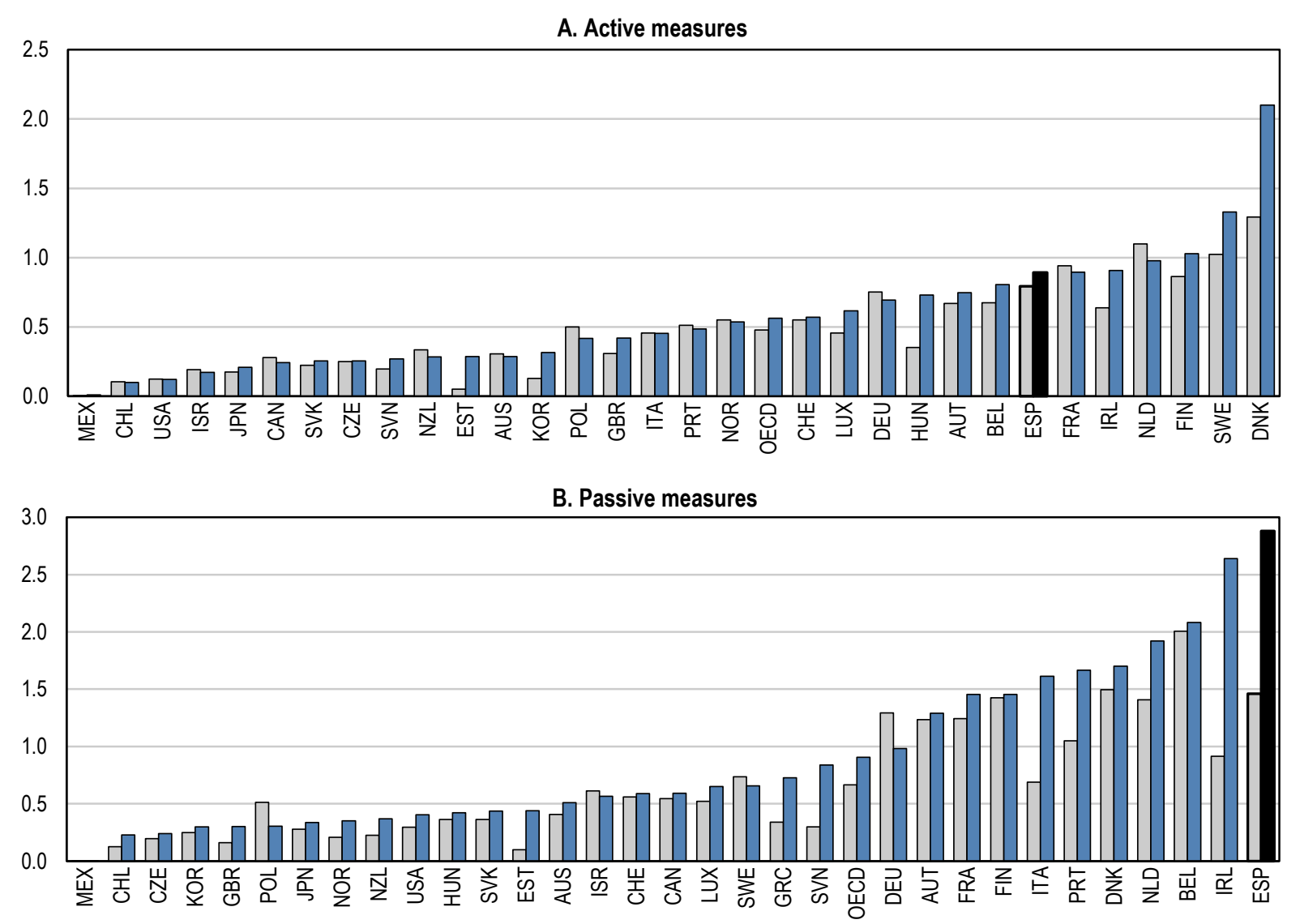

1. Active measures cover public employment services and administration (placement and related services, benefit administration), training, employment incentives, supported employment and rehabilitation, direct job creation and start-up incentives. Passive measures cover out-of-work income maintenance and support, and early retirement.

2008 for Chile in Panel A.

3. 2011 for Australia, Ireland, Israel, Luxembourg, Poland and Spain; 2009 for the United Kingdom in Panel A; 2010 for Greece and the United Kingdom in Panel B.

Source: OECD (2014), OECD Employment Outlook 2014. 
Table 5. Average caseload in the public employment service

$2011^{1}$

\begin{tabular}{lccr}
\hline & $\begin{array}{c}\text { Registered job } \\
\text { seekers (thousand) }\end{array}$ & $\begin{array}{c}\text { Public employment } \\
\text { service (PES) staff } \\
\text { (thousand) }\end{array}$ & $\begin{array}{c}\text { Job seekers per PES } \\
\text { staff member }\end{array}$ \\
\hline Spain & $\mathbf{5 7 4 5 . 3}$ & $\mathbf{2 1 . 4}$ & $\mathbf{2 6 9}$ \\
Austria & 258.6 & 4.9 & 53 \\
Belgium & 547.4 & 10.0 & 54 \\
Czech Republic & 509.2 & 7.3 & 70 \\
Denmark & 207.7 & 5.8 & 36 \\
Estonia & 53.2 & 0.5 & 108 \\
Finland & 470.4 & 3.9 & 120 \\
Germany & 5207.6 & 110.0 & 47 \\
Greece & 576.6 & 3.4 & 169 \\
\hline Ireland & 444.9 & 0.6 & 778 \\
Netherlands & 625.6 & 5.0 & 125 \\
Poland & 2011.2 & 23.8 & 84 \\
\hline Portugal & 639.7 & 3.6 & 177 \\
\hline Slovak Republic & 401.5 & 2.3 & 172 \\
\hline Slovenia & 110.7 & 1.0 & 112 \\
\hline Sweden & 679.0 & 10.8 & 63 \\
\hline United Kingdom & 1571.7 & 72.9 & 22 \\
\hline
\end{tabular}

1. 2010 for job seekers for Greece.

2. Data on the total number of jobseekers registered with the PES are broken down into those considered as registered unemployed according to national definitions and other registered jobseekers.

3. Latest data available from the country fiches of the European Commission website, 2010 or 2011 in most cases but 2012 for Spain. The remit of the PES varies across countries in terms of groups covered (e.g. disabled, employed jobseekers) and services provided (e.g. career guidance, in-house training). For more details see the "PES Business Models" study by Mobility Lab available from the European Commission website (link below).

Source: Registered job seekers from Eurostat (2014), "Labour Market Policy”, Eurostat Database, May; PES staff numbers from Spain provided by the Ministry of Employment and Social Security; other PES staff numbers from European Commission, Employment, Social Affairs and Inclusion, Public Employment Services, http://ec.europa.eu/social/main.jsp?catld=105\&langld=en, accessed April 2014.

Effective ALMPs are based on the mutual obligation principle, whereby the unemployed receive income and employment support and in return, are required to participate actively in job-search and/or training (Martin, 2000; Kluve 2006). The obligations of the unemployed appear insufficient. The unemployed must accept an adequate job offer but definitional uncertainty of what is "adequate" facilitates refusal making enforcing obligations of the jobseeker harder. The unemployed must also participate in recommended training but there are no systematic job search obligations. In addition, modern activation tools, such as profiling the unemployed to select them into low or more intense assistance groups, are only starting to be developed and systematic sharing of best PES practices across regions just started in early 2014.

Tightly linking activation and the payment of unemployment benefits in line with best practice is more challenging in Spain because activation is the responsibility of the regions, while the centre pays unemployment benefits. Communication between the regions and the national Public Employment Service (Servicio Público de Empleo Estatal, SEPE) has been stepped up, resulting in increased savings from monitoring and control activities. The central government is also building a new activation strategy 2014-16 (a cooperative model) with different components (profiling, a single Spain-wide portal for searching for job offers, best practice sharing between regional and the national PES, modernising the training system for the unemployed, contracting out) and a technical centre to provide common tools such as information technology. The central activation strategy will have a set of objectives and build a set of impact measurements. These will be used to allocate central government funding to the regions for activation. In $201315 \%$ of central government funding was provided to the regions on a performance basis, and this has increased to $40 \%$ in 2014 and will reach $60 \%$ in 2015. 
These changes appear to be going in the right direction, but implementation at the regional level is crucial and has been slow. In particular, the PES has been too slow to develop activation assistance to the unemployed based on modern practice, operating predominantly in a passive way. More efforts need to be made to implement activation reforms faster to avoid a crisis legacy of a large permanently unemployed cohort. Resources need to be shifted to activation from other government expenditure areas. The first priority should be to improve PES efficiency by increasing the range of tools and improving the institutional framework so as to strengthen the capacities of the PES. Once this is done the number of caseworkers at the PES may need to be increased. Fiscal constraints remain tight so a more cost-efficient measure than hiring new staff would be to redeploy existing staff to case-working roles. Experience in Ireland suggests that with some training existing Labour Ministry staff can be redeployed from more administrative functions to case working quite successfully as staff typically already have roles that require significant personal interaction. Contracting out placement to the private sector can also potentially help but care needs to be taken to avoid "cream-skimming" of the most employable candidates by private providers. Empirical evidence suggests there may also be a substitution effect whereby those unemployed that receive external placement assistance may get a job but at the expense of those unemployed that did not (Crépon et al., 2013). In this context, the central government's stronger collaboration on placement services with private agencies for participating regions, where private providers will receive payments made according to the employability profile of the person placed, is promising.

Placement services (whether public or private) should aim to have a regularly monitored individual assistance and obligations plan in place for all unemployed within a time limited period of registering as unemployed. Profiling can help with resource allocation by prioritising those with a high risk of falling into long-term unemployment for faster individual assistance, while those considered at low risk may initially only need to attend a group information session and sign a standard obligations contract. One element of an enhanced obligations approach should be to define more clearly what can be regarded as an adequate job offer using objective criteria such as the minimum pay premium the job must offer over unemployment assistance.

Part of the new activation strategy is to continue to modernise the training system by increasing the role of private sector providers in training and also the use of competitive tendering for allocating public training funds. More weight will be given to analysis of future job prospects in allocating training funds but predicting labour demand is difficult. To increase the labour market relevance of training for the unemployed, the regions should be incentivised using central government performance based funding to introduce systematic evaluation of training incomes and reallocate funding towards those schemes that prove ex post to be the most effective in increasing employability.

The high proportion of very low-skilled unemployed as well as low skill levels in the adult population more generally means that continuing education at the upper secondary (intermediate VET) level has a large role to play. A dual training system for the unemployed is being developed and six pilot projects in cooperation with Chambers of Commerce are underway in 2014. However, the strengthened vocational education track with a higher practical component being introduced at secondary school (discussed above) should also be made available in parallel to the adult unemployed. International experience suggests that increasing work-based training opportunities, such as apprenticeships and internships, is likely to pay-off as it facilitates the labour entry, particularly of youth (OECD, 2009b). An appealing feature of this type of scheme is that it allows employers to train a potential employee for the actual needs of the company, as international experience shows that training needs to be targeted, and employer-employee initiated training can help achieve this since it is difficult for the public authorities to predict skill demands (Carcillo and Grubb, 2006).

\section{The wage bargaining system is in transition and wage responsiveness can be further enhanced}

Rigidities in the wage bargaining regime, particularly high reliance on sectorial wage agreements and wage indexation to inflation (now with reduced use), have contributed to a lower responsiveness of wages to unemployment in Spain. A much higher unemployment rate has been required to induce a fall in nominal wages than other countries (Figure 18). Significant reforms to both the wage bargaining and employment protection regimes were undertaken in 2012. These increased the potential for greater responsiveness of wages 


\section{$\mathrm{ECO} / \mathrm{WKP}(2014) 68$}

to economic conditions and reduced employment protection for permanent contracts (OECD, 2012c). A recent OECD review of the reforms, which used statistical techniques to distinguish policy from other effects, found that they had contributed to wage moderation and increased hiring on permanent contracts (OECD, 2013f). However, further time will be required to fully evaluate the effect of the reforms. As the authors acknowledge, only a short period had elapsed at the time of the evaluation, and it is difficult to establish an effective counter-factual. Indeed, the evaluation was done during a period of significant evolution in cyclical conditions as the economy moved from a long recession towards recovery and it is hard to distinguish between cyclical and policy effects in these circumstances.

Figure 18. Phillips curve: wages and unemployment rate

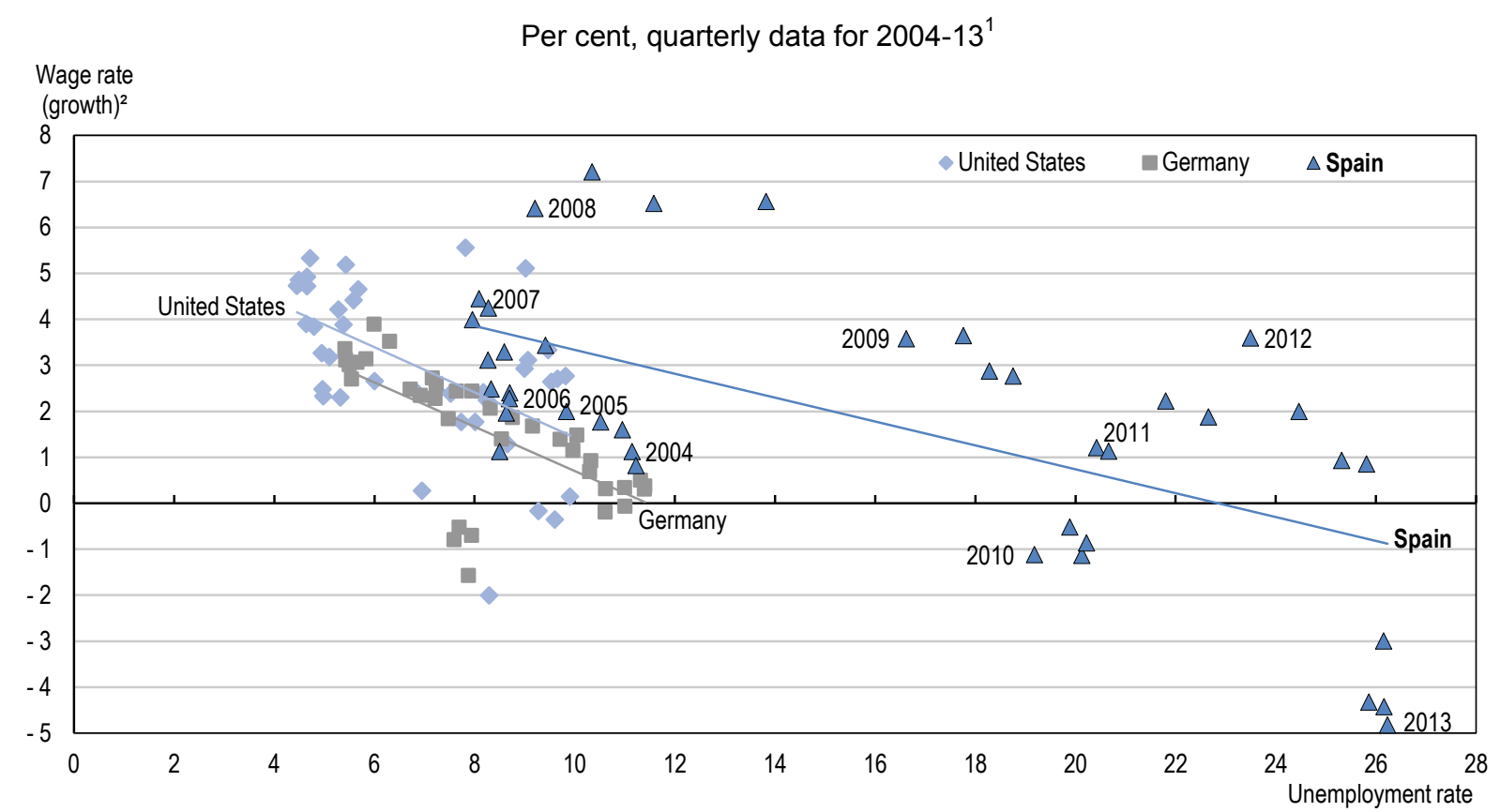

1. Year labels for Spanish data indicate first quarter.

2. Wage rate private sector, year-on-year percentage change. No data is available for Germany for 2013.

Source: OECD (2014), OECD Economic Outlook: Statistics and Projections (database), July.

An important component of the reforms was to abolish the indefinite automatic extension of sectorial wage agreements ("ultra-activity"), replacing it with a one-year maximum automatic extension. In a welcome development, many of these unrepresentative and competition stifling agreements have now been renegotiated or extended for a short-period to allow for renegotiation. In the few cases where they actually ceased altogether, it is not clear as yet what will replace them. However, there has not been a general expiration of previous working conditions. The new bargaining regime allows firms to opt-out of sectorial collective agreements but there appears to be little opting out. Only $5 \%$ of workers were affected by opt-outs covered by firm level agreements in early 2014 (Banco de España, 2014). However, the prospect of firms opting-out or signing their own agreements seems to have moved sectorial agreements towards adapting better to economic conditions. If needed, on the basis of further evaluation of recent reforms, the government could increase their effectiveness through further refinements, starting with imposing, and gradually increasing, representation requirements for both unions and firms for new sectorial collective agreements. As a second option, the government could further increase the effectiveness of the reform by requiring firms to "opt-in" rather than "opt-out" of sectorial collective agreements. A more decentralised wage bargaining system and greater heterogeneity in wage and working conditions would generate a more dynamic and employment-rich labour market. Cross-country evidence shows new firms are the most important source of employment creation including in Spain (Bravo-Biosca et al., 2013; Criscuolo et al., 2014), and establishing different wage and employment conditions is an important way for them to compete with established firms. 
More needs to be done to reduce dualism

A high level of protection for permanent relative to temporary contracts has led to marked labour market dualism (Figure 19), which increases unemployment volatility and inequity, reduces firm and worker investment in training and hampers labour reallocation. It also reduces total factor productivity growth (Dolado et al., 2011). Despite the reduction in the employment protection for new permanent contracts in the 2012 reform to just below the OECD average, temporary contracts are still widely used. The share of workers with temporary contracts fell during the crisis as many temporary contracts were not renewed but the share has started to rise again and the duration of these contracts is often shorter than those before the crisis.

Figure 19. Employment protection legislation ${ }^{1}$

Individual dismissal of workers with regular contracts
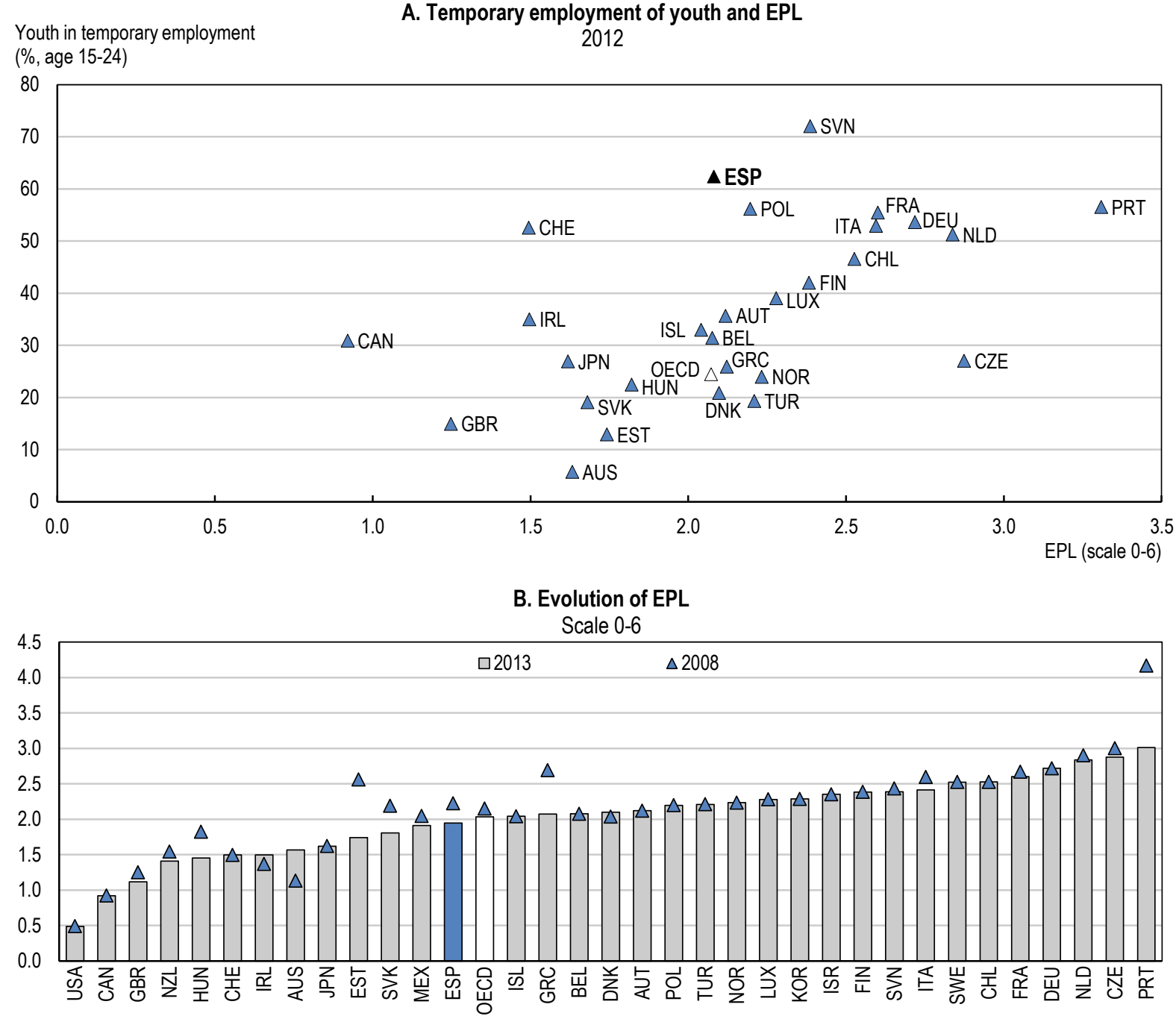

1. Synthetic indicator of the strictness of employment protection legislation (EPL) with a scale of 0-6 from least to most restrictive. The EPL shown in this figure incorporates three aspects of dismissal protection: procedural inconveniences that employers face when starting the process; notice periods and severance pay; and difficulty of dismissal.

Source: OECD (2014), OECD Employment and Labour Market Statistics (database), July.

In March 2014, the government introduced a temporary, conditional cut in employer social security contributions for new permanent contracts to a flat rate of EUR 100 per month. The reduction will apply to positions created between 25 February and 31 December 2014 and will be valid for two years from the start of the contract. Following the two-year period firms with less than ten employees are entitled to a permanent 


\section{ECO/WKP(2014)68}

$50 \%$ reduction in employer social security contributions. The cut is conditional on the firm having not fired workers in the previous six months and the contract resulting in a net increase in employment.

The most recent data on new hiring show a significant increase of $23.9 \%$ in the annual growth of new permanent hiring. However, the across the board flat rate is expensive, with most lost revenue coming from higher paid jobs. In addition, temporary measures cannot be expected to fully stimulate long-term hiring or investment plans. It would be preferable to introduce a permanent cut in employer social security contributions focussed on lower-paid workers where the need to stimulate labour demand is the most acute. Simulations conducted for the Fiscal Expert's Commission show a larger effect on GDP and employment from cutting employer social security contributions than income taxes (Comisión de Expertos, 2014). To keep administrative costs low and reduce barriers to firm growth conditionality and discriminating between firms based on firm size should be avoided.

One key issue to make the 2012 reform successful is a wider use by firms of "fair" dismissals justified by law as opposed to "unfair" dismissals, which are more costly. The share of fair dismissals has increased from $30 \%$ in 2010 to nearly $60 \%$ of total dismissals. There is room for further increase although the economic cycle also plays a role in the share of fair dismissals - during a downturn the share is likely to increase. If the increase stalls at this point this could indicate that either firms are still worried about reclassification by the judges or that judges continue to frequently reclassify dismissals as "unfair". The latter would be worrisome for the success of the reform.

To further reduce duality, the government should pursue a greater convergence of termination costs between fixed-term and permanent contracts (Blanchard and Tirole, 2003; Cahuc, 2012). An important prerequisite for this to be effective is to further restrict the grounds for ordering reinstatement in cases of unfair dismissal to false reasons, discrimination and prohibited grounds only (OECD, 2014).

\section{Improving labour mobility can help to reduce unemployment}

There are large and persistent differences in unemployment rates from region to region, (Figure.20). Wage inflexibility arising from nationwide sectorial agreements that have set wages too high relative to regional productivity, which varies significantly across regions, can partially explain this (OECD, 2007). 
Figure 20. Regional unemployment rates ${ }^{1}$

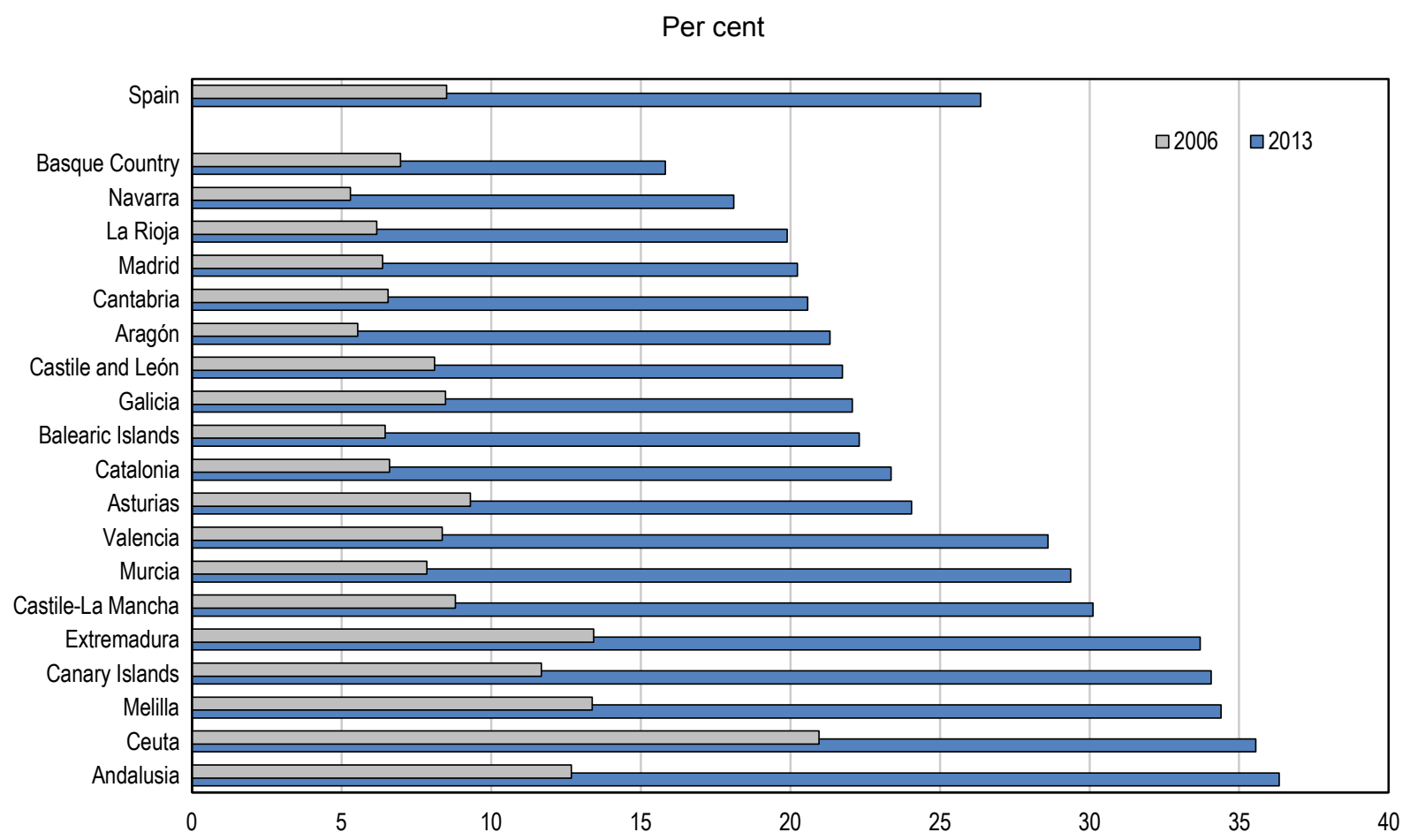

1. The results for Ceuta and Melilla should be viewed with caution as they may be affected by large sampling errors.

Source: INE (2014), "Economically Active Population Survey", INEbase, Instituto Nacional de Estadística, April.

Such large and persistent differences in unemployment rates should provide an incentive for the unemployed to move from high to low unemployment regions. In an international context (for example Ireland and the United Kingdom) this gap is a significant explanatory variable of net migration flows (Fitzgerald et al., 2008). However, barriers to labour mobility, including the monetary costs of moving and social ties, can impede the flow of unemployed. In Spain, internal migration does not appear to be reacting to the incentives provided by large differences in regional unemployment rates, with no apparent correlation between regional net migration and regional unemployment rates, even allowing for some reaction time (Figure 21). 
Figure 21. Provincial unemployment and migration

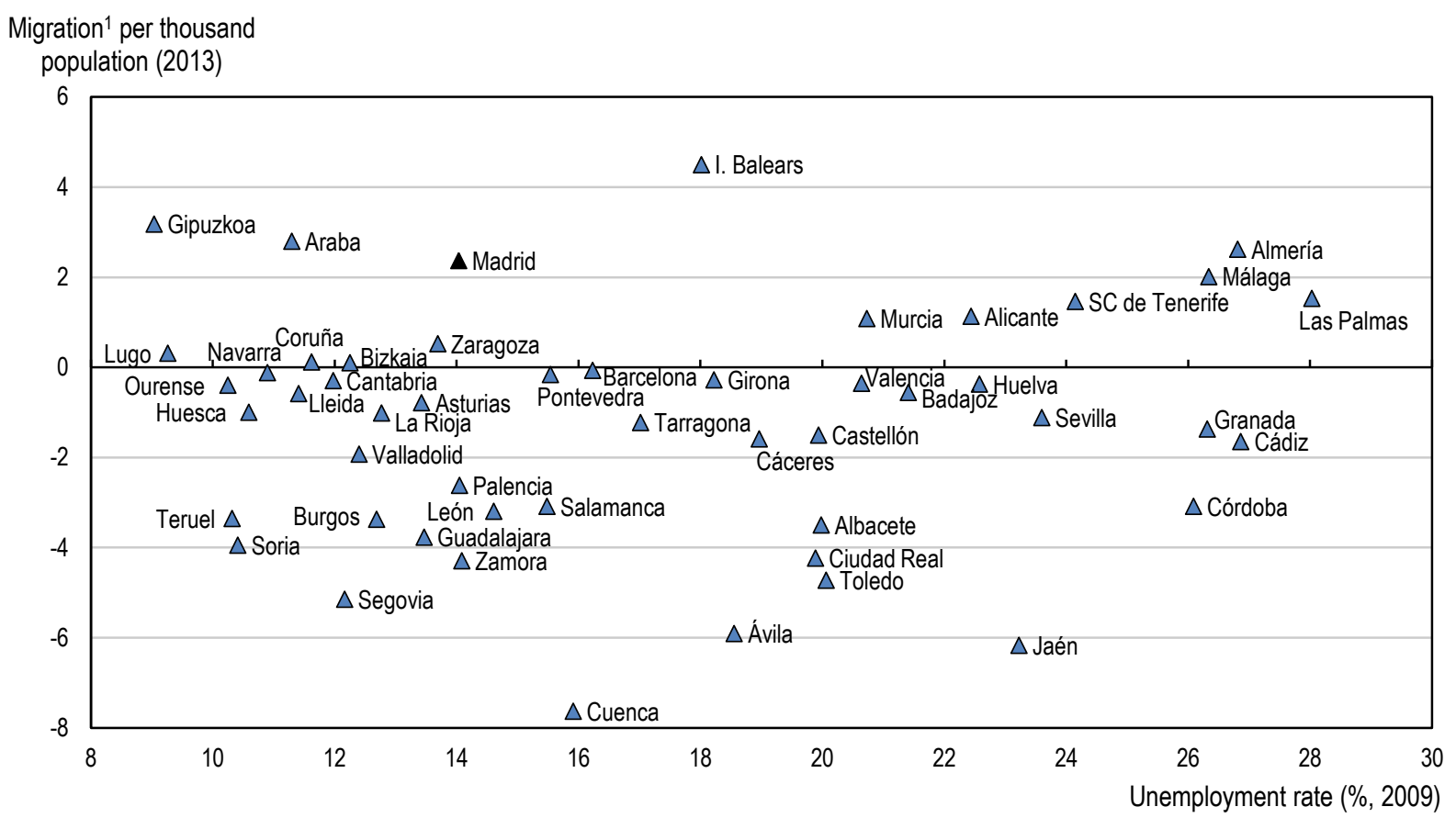

1. Inter-provincial migration balance, provisional data.

Source: INE (2014), INEbase, Instituto Nacional de Estadística, July.

A long-standing impediment to internal labour mobility is a strong bias towards home ownership and an inflexible and under-developed rental market (OECD, 2008). The rate of home ownership has increased over time and is very high by international standards at over $80 \%$. Demographic factors can only partially explain the increase in home ownership (Andrews and Caldera Sánchez, 2011). The tax system has been biased towards home ownership. Investment in rental property has also been discouraged by strict tenancy laws, which imposed five year fixed-term leases and a requirement for the landlord to preferentially sell to the tenant. Investment has been further discouraged by difficulties in enforcing evictions, for example for failing to pay the rent, due to inefficiencies in the court system (OECD, 2008). There has also been very little investment in rental properties by institutional or corporate investors, with most rental agreements being between private landlords and tenants.

A number of reforms have been taken to improve the supply of rental property by providing new investment vehicles and increasing the flexibility of rental markets, and on the demand side to reduce home ownership bias. The withdrawal of deductibility from income tax of mortgage payments has helped to reduce the tax bias towards housing ownership. In 2009 the government introduced legislation allowing the possibility to set-up Real Estate Investment Trusts (REITs), akin to a mutual fund and often listed on stock exchanges, to encourage investment in rental property by providing a liquid and diversified method of investing in real estate. In January 2013 REITs legislation was modified to allow for more flexibility to adapt its taxation to that applied in other countries. REITs are widely used in several OECD countries, including Australia and the United States, and investor interest in Spain in 2013 and 2014 has been reportedly strong.

The government also passed a new Rental Housing Act in May 2013, which provides for shorter three year fixed-term leases (although the tenant can exit the lease earlier) and for shorter automatic lease extensions (one year instead of three). It also removes the obligation to sell preferentially to the tenant and allows landlords to terminate the lease with notice if they sell the property. It replaces indexing of rents to the consumer price index with rents to be freely negotiated between the parties. It allows the eviction of tenants ten days after filing of a lawsuit for non-payment of rent - previously a declaratory judgment was required before eviction. Following the reform, rent setting flexibility has increased to equal the highest in the EU, although tenant protection is still above the median in the EU (Cuerpo et al., 2014). 
A pre-requisite for ensuring an efficient rental housing market requires reducing the high level of formalism and slow speed of the Spanish judicial system. A network of local arbitration bodies with simple procedures requiring no legal representation should be set up to handle landlord-tenant disputes in the first instance. The government should also introduce periodic leases (for example, one month rolling leases that continue unless one party gives notice) to give greater scope for landlords and tenants to match rental contracts to labour market situations such as temporary contracts, seasonal work or those that need to move frequently to advance in their careers. Living in social housing reduces willingness to move residence to obtain a job and thereby unemployment durations (Barceló, 2006; Ménard and Sellem, 2010). To further facilitate labour mobility, while maintaining social protection, the government should reallocate some funding away from social housing towards means tested housing benefits.

\section{A more family friendly labour market: boosting employment of women}

The employment rate of women aged 25-54 is low in Spain (Figure 22). As discussed above, at current low fertility rates the working age population will shrink markedly reducing potential growth. It will also sharply decrease the ratio of the working age to retired population making it more difficult to fund pensions and health expenditures.

Figure 22. Fertility rates and employment rates of women $2012^{1}$

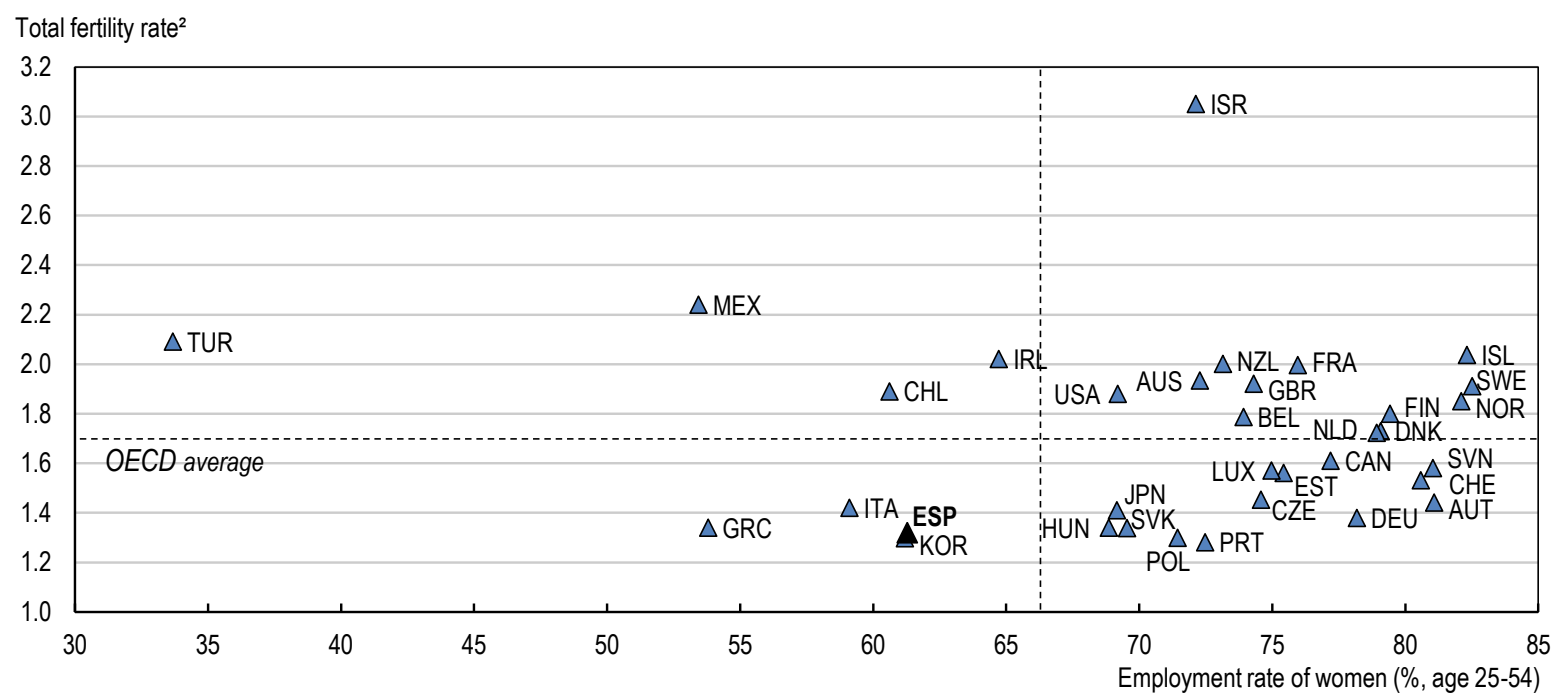

1. 2011 for Canada and Chile.

2. The total fertility rate is the number of children that would be born to a woman if she were to live to the end of her childbearing years and if the likelihood of her giving birth to children at each age was the currently prevailing age-specific fertility rate. See indicator SF 2.1 of the OECD Family Database for further information.

Source: OECD (2014), OECD Employment and Labour Market Statistics (database), July and OECD (2014), OECD Family Database, June, www.oecd.org/social/family/database.

The participation rate of women continued to rise during the crisis and is close to the OECD median (Figure 23). The low employment ratio of women is mainly a result of high general unemployment in Spain. A fall in the unemployment rate of women from over $20 \%$ to around $8 \%$ would increase the employment ratio to around the OECD median. 
Figure 23. Labour force participation rate of women aged 25-54

Labour force as a percentage of population in same age group

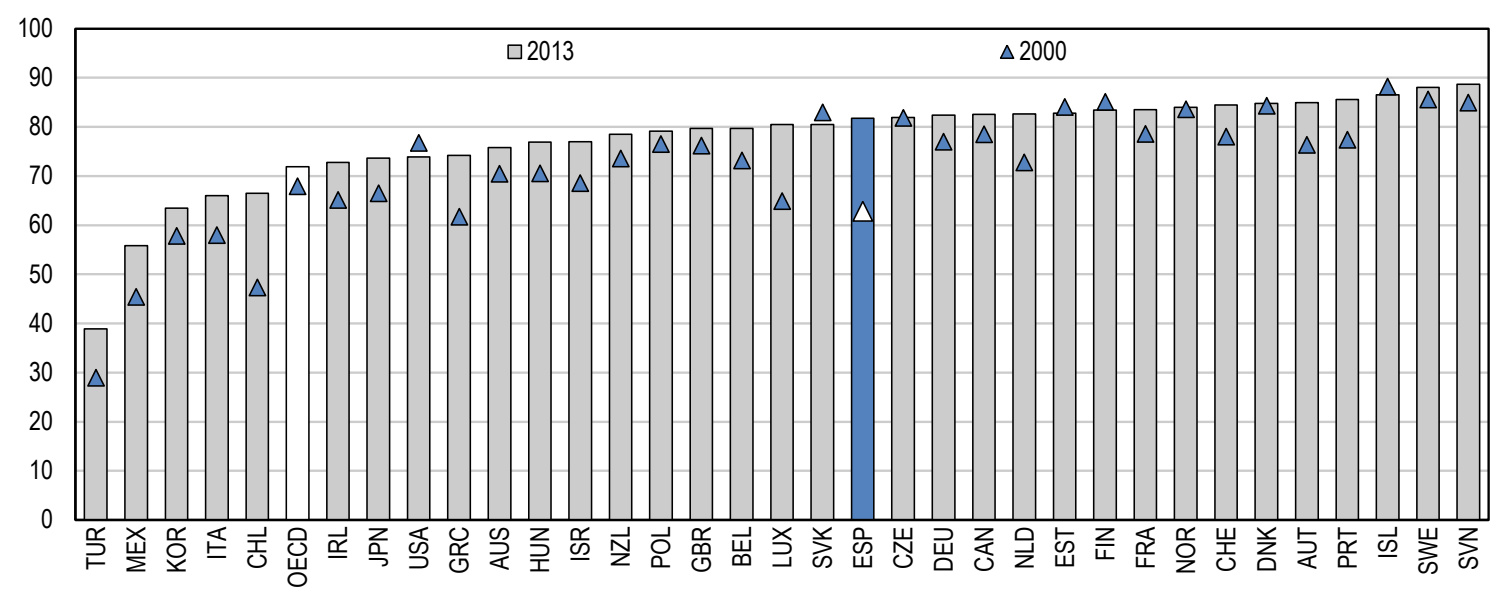

Source: OECD (2014), OECD Employment and Labour Market Statistics (database), July.

There appears to be room to remove barriers to combining paid employment and motherhood to increase women's labour force participation further. Less dualism and more time flexibility including a higher use of permanent part-time contracts, which is low by international standards, would both help. The government should re-examine how to protect parents that choose to work part-time from dismissal. The law allows those on permanent contracts with children aged under twelve to reduce their working-time even without employer consent and with a protection from dismissal. Empirical work suggests this increased part-time working by women on permanent contracts but also increased the dismissals of non-eligible women and the use of fixedterm contracts to hire women of child-bearing age (de la Rica and Gorjón García, 2013). Measures to fight duality would also help to eliminate this type of substitution towards fixed-term contracts.

Benchmarking suggests that there are a number of potential policy levers at Spain's disposal to make it easier to combine work and family and thereby encourage higher participation in the labour force by women (Table 1.6). In particular countries with both higher fertility and employment of women (the Nordics, France and New Zealand) have higher public spending on family benefits and childcare and early education services, lower childcare fees as proportion of wages, higher pre-school enrolment rates, a higher of share of women on leave for children aged under one and a lower share of both men and women working longer working hours (40+ per week) and a higher share of woman in part-time employment. The end of the working day is also typically earlier in these countries than in Spain, where family unfriendly late finishing times of $8 \mathrm{pm}$ are common. Several of the levers are fiscally costly so policy should focus in the shorter-term on improving the family friendliness of working hours and parental leave norms. This could include setting a regulatory norm of compulsory core work hours of $10 \mathrm{am}$ to $4 \mathrm{pm}$ around which full-time employees are free to vary their starting and finishing times to meet their total hour's obligations, unless otherwise set by fixed shift work schedules. 
ECO/WKP(2014)68

Table 6. Working environment for families: Spain in international comparison

\begin{tabular}{|c|c|c|c|c|c|c|c|}
\hline \multirow[b]{2}{*}{ Indicator } & \multirow[b]{2}{*}{ Unit } & \multirow[b]{2}{*}{ Year } & \multirow[b]{2}{*}{ Spain } & \multicolumn{4}{|c|}{$\mathrm{OECD}^{1}$} \\
\hline & & & & $\begin{array}{c}\text { Best } \\
\text { performers }{ }^{2}\end{array}$ & Average & $\begin{array}{l}25-75 \% \\
\text { interquartile } \\
\text { range }\end{array}$ & $\begin{array}{c}\text { Number } \\
\text { of } \\
\text { countries }\end{array}$ \\
\hline Public expenditure on & $\%$ of GDP & 2009 & & & & & \\
\hline $\begin{array}{l}\text { Family benefits in cash, services and tax } \\
\text { measures }\end{array}$ & & & 1.8 & 3.7 & 2.6 & $1.6-3.6$ & 33 \\
\hline Childcare and early education services & & & 0.6 & 1.3 & 0.7 & $0.4-0.9$ & 33 \\
\hline Family cash benefits & $\begin{array}{l}\% \text { of average } \\
\text { wage }\end{array}$ & 2011 & 1.0 & 3.6 & 3.8 & $2.1-5.4$ & 30 \\
\hline $\begin{array}{l}\text { Childcare fees per two-year old attending } \\
\text { accredited early-years care and education } \\
\text { services }\end{array}$ & $\begin{array}{c}\% \text { of average } \\
\text { wage }\end{array}$ & 2008 & 25 & 14 & 21 & $10-28$ & 28 \\
\hline Children aged less than three in pre-school & $\%$ & 2010 & 39 & 48 & 33 & $19-46$ & 30 \\
\hline $\begin{array}{l}\text { Child-to-teaching staff ratio in formal day- } \\
\text { care services, } 0-3 \text { year-olds }\end{array}$ & Ratio & 2008 & 14 & 11 & 15 & $12-18$ & 25 \\
\hline Leave & Weeks & 2013 & & & & & \\
\hline Paid maternity & & & 16 & 15 & 18 & $14-19$ & 32 \\
\hline Paid paternity & & & 2 & 7 & 5 & $0-9$ & 32 \\
\hline Unpaid parental & & & 0 & 22 & 23 & $0-22$ & 32 \\
\hline Maternity leave payment rates & $\begin{array}{l}\% \text { of average } \\
\text { wage }\end{array}$ & 2008 & 102 & 77 & 77 & $66-93$ & 27 \\
\hline $\begin{array}{l}\text { Share of employed women with a child } \\
\text { under age one on leave }\end{array}$ & $\%$ & 2006 & 27 & . & 45 & $27-72$ & 17 \\
\hline Share of part-time employment & $\%$ & 2012 & & & & & \\
\hline All persons & & & 15 & 17 & 16 & $8-20$ & 32 \\
\hline Women & & & 24 & 24 & 24 & $12-33$ & 32 \\
\hline $\begin{array}{l}\text { Average effective tax rates for parents } \\
\text { entering employment at } 67 \% \text { of average } \\
\text { wage, spouse earnings also } 67 \%\end{array}$ & $\%$ & 2008 & 16 & 37 & 33 & $23-41$ & 31 \\
\hline $\begin{array}{l}\text { Parents who work more than } 40 \text { hours a } \\
\text { week, with two children aged } 0-14\end{array}$ & $\%$ & 2008 & & & & & \\
\hline Women & & & 41 & . & 47 & $22-74$ & 19 \\
\hline Men & & & 84 & . & 80 & $73-94$ & 19 \\
\hline
\end{tabular}

Source: OECD (2014), OECD Family Database, www.oecd.org/social/family/database and OECD Employment and Labour Market Statistics (database), May.

Spain's paid maternity leave is around the OECD average. The maximum unpaid parental leave is also long. However, the proportion of employed women on leave with a child under one year old is low suggesting (assuming similar preferences as in other OECD countries) that in practice it is not easy for employed women to take an extended period of leave in Spain following the birth of a child. The high unemployment rate and dualistic labour market with many younger women on precarious temporary contracts means women might be reluctant to take extended leave for fear of being fired. In addition, taking extended leave may not be perceived well in many workplaces in Spain. Around $27 \%$ of men and $31 \%$ of employed women report requesting shorter working hours or leave for family reasons as actually or possibly having been negative for their career (Ministry of Labour and Immigration, 2011). This appears to be a very high share given that between around $40 \%$ to $46 \%$ of working men and women live in households with children under the age of 14 or with a dependent person and therefore are likely to make such a request.

The government should also act to improve average childcare quality while not stifling competition. Preschool enrolment of 0-3 year-olds has increased a lot over the past decade and is above the OECD average; 


\section{$\mathrm{ECO} / \mathrm{WKP}(2014) 68$}

and a competitive market of public and private providers has developed. The regulation of the sector was devolved to the regions in 2006 and the standards vary a lot across them. To help guarantee a minimum quality standard across Spain without overly impeding innovation and the variety of the offer, the central government should set a national minimum standard for safety and quality standards, including for the required training for carers and teachers. Broadening access to early childhood education, especially to poorer households, is also an important lever for lowering elevated school drop-out rates and improving adult life outcomes (Heckman, 2008).

\section{Box 1. Recommendations for sustainable boosting medium-term growth}

- Further increase the work-based component of existing school-based vocational education and training completed at firms. Schools should be more flexible in applying criteria to move to upper secondary school education.

- Publicise widely information on university graduate labour market outcomes by degree and institutions and ease the compulsory requirements to offer a minimum number of degree courses at under-graduate level.

- Raise the quality of innovation and strengthen competitiveness by encouraging greater scale and specialisation of universities and research organisations, by extending performance based resources allocation and the application of international peer review and by providing more career opportunities for highly qualified researchers.

- Retain and review the research and development (R\&D) tax credit including the limits on the amounts that can be claimed and cooperate with larger research organisations to promote its use among younger firms. Streamline the certification process for R\&D.

- Create an alternative career progression track at both universities and the Council for Scientific Research for researchers involved in knowledge transfer and commercialisation activities. Increase the ceiling on the share of university staff that can be hired on ordinary labour contracts.

- Equalise pricing of greenhouse gas emissions across sources and fuels using taxes and fees and move towards a single carbon tax. Increase the use of pricing tools to manage household and agricultural water demand by charging for environmental and scarcity costs. Ensure predictable and sustainable policy support to low-carbon technologies.

- Strengthen active labour market policies by improving vocational training, strengthening the capacities and efficiency at the public employment services and enhancing coordination between the different levels of administration.

- Reallocate spending to active labour market policies. Develop further profiling and individualised activation plans for the unemployed. Adjust funding for unemployed training based on tracking of labour market outcomes.

- To further increase the flexibility of wage bargaining, if needed require firms to gradually increase representation requirements for sectorial collective agreements or, as a second option "opt-in" rather than "optout" of sectorial collective agreements.

- To further reduce dualism, if the courts continue to find mainly in favour of employees in unfair dismissal cases, the government should legislate to further define the conditions for fair dismissals. The government should move towards converging termination costs for fixed term and permanent contracts.

- To improve the rental housing market and labour mobility, introduce a network of local arbitration bodies to handle landlord-tenant disputes, introduce periodic rolling leases and shift some funding from social housing to means tested housing benefits.

- Improve the family friendliness of the working environment by setting a regulatory norm of compulsory core work hours. Set a national minimum standard for safety and quality standards for childcare providers. 


\section{Bibliography}

Andrews, D. and A. Caldera Sánchez (2011), "Drivers of Homeownership Rates in Selected OECD Countries", OECD Economics Department Working Papers, No. 849, OECD Publishing, http://dx.doi.org/10.1787/5kgg9mcwc7jf-en.

Andrews, D. and C. Criscuolo (2013), "Knowledge-Based Capital, Innovation and Resource Allocation", OECD Economics Department Working Papers, No. 1046, OECD Publishing, http://dx.doi.org/10.1787/5k46bj546kzs-en.

Banco de España (2014), Boletín Estadístico (database), Table 24.22.

Barceló, C. (2006), "Housing Tenure and Labour Mobility: A Comparison across European Countries", Documents de Trabajo, No. 0603, Banco de España.

Bell, D.N.F. and D.G. Blanchflower (2009), "What Should Be Done about Rising Unemployment in the UK", IZA Discussion Papers, No. 4040, Institute for the Study of Labor.

Blanchard, O.J. and J. Tirole (2003), "Contours of Employment Protection Reform", MIT Department of Economics Working Paper, No. 03-35, Massachusetts Institute of Technology.

Box, S. (2009), "OECD Work on Innovation - A Stocktaking of Existing Work”, OECD Science, Technology and Industry Working Papers, No. 2009/02, OECD Publishing, http://dx.doi.org/10.1787/227048273721.

Braathen, N.A. (2011), "Carbon-Related Taxation in OECD Countries and Interactions Between Policy Instruments", in L. Kreiser et al. (eds.), Environmental Taxation and Climate Change: Achieving Environmental Sustainability Through Fiscal Policy, Critical Issues in Environmental Taxation, Edward Elgar Publishing.

Bravo-Biosca, A., C. Criscuolo and C. Menon (2013), "What Drives the Dynamics of Business Growth?", OECD Science, Technology and Industry Policy papers, No. 1, OECD Publishing, http://dx.doi.org/10.1787/5k486qtttq46-en.

Busom, I., B. Corchuelo and E. Martínez-Ros (2012), “Tax Incentives and Direct Support for R\&D: What Do Firms Use and Why?", Business Economics Working Papers, No. id-11-03, Universidad Carlos III, Instituto sobre Desarrollo Empresarial "Carmen Vidal Ballester".

Cahuc, P. (2012), "For a Unified Contract", European Labour Law Journal, Vol. 3, No. 3.

Caldera, A. and O. Debande (2010), "Performance of Spanish Universities in Technology Transfer: An Empirical Analysis", Research Policy, Vol. 39, No. 9, Elsevier.

Carcillo, S. and D. Grubb (2006), "From Inactivity to Work: The Role of Active Labour Market Policies", OECD Social, Migration and Employment Working Papers, No. 36, OECD Publishing, http://dx.doi.org/10.1787/687686456188.

Cochado, A., L.D. Anadón and P. Linares (2012), "Innovación en énergia en España” (Innovation in energy in Spain), Informe, http://eforenergy.org/docpublicaciones/informes/Informe_2012.pdf.

Comisión de Expertos (2014), "Informe de la Comisión de Expertos para la Reforma del Sistema Tributario Español" (Report of the Committee of Exports for the reform of the tax system), Government of Spain, February. 
Crépon, B., E. Duflo, M. Gurgand, R. Rathelot and P. Zamora (2013), "Do Labour Market Policies Have Displacement Effects? Evidence from a Clustered Randomized Experiment", Quarterly Journal of Economics, Vol. 128, No. 2, Oxford University Press, http://dx.doi.org/10.1093/qje/qjt001.

Criscuolo, C., P.N. Gal and C. Menon (2014), “The Dynamics of Employment Growth: New Evidence from 18 Countries", OECD Science, Technology and Industry Policy Papers, No. 14, OECD Publishing, http://dx.doi.org/10.1787/5jz417hj6hg6-en.

Criscuolo, C., D. Czarnitzki, C. Hambro and J. Warda (2009), "Design and Evaluation of Tax Incentives for Business Research and Development: Good Practice and Future Development", final report submitted by the Expert Group on Impacts of R\&D Tax Incentives to the European Commission, Directorate General Research, 15 November.

Cuerpo, C., S. Kalantaryan and P. Pontuch (2014), "Rental Market Regulation in the European Union", Economic Papers, No. 515, European Commission, http://dx.doi.org/10.2765/69909.

Czarnitski, D. and B. Ebersberger (2010), "Do Direct R\&D Subsidies Lead to Monopolisation of R\&D in the Economy?", ZEW Discussion Papers, No. 10-078, Centre For European Economic Research.

De la Rica, S. and L. Gorjón García (2013), "The Impact of Family-Friendly Policies on the Labor Market: Evidence from Spain and Austria", Documento de Trabajo, 2013-15, Fundación de Estudios Aplicada (FEDEA), November.

Dolado, J.J., S. Ortigueira and R. Stucchi (2011), "Does Dual Employment Protection Affect TFP? Evidence from Spanish Manufacturing Firms", Economics Working Papers, No. 11-37, Charles III University of Madrid.

Duval, R. (2008), “A Taxonomy of Instruments to Reduce Greenhouse Gas Emissions and their Interactions", OECD Economics Department Working Papers, No. 636, OECD Publishing, http://dx.doi.org/10.1787/236846121450.

European Commission (2013), Research and Innovation Performance in EU Member States and Associated Countries: Innovation Union Progress at Country Level, 2013.

Felgueroso, F., M. Gutíerrez-Domench and S. Jiménez Martin (2013), "Dropout Trends and Educational Reforms: the Role of the LOGSE in Spain", Documento de Trabajo, No. 2013-04, Fundación de Estudios Aplicada (FEDEA).

FitzGerald, J. et al. (2008), “Medium-Term: 2008-2015”, Forecasting Report, No. 11, The Economic and Social Research Institute.

Gonzalez Pandiella, A. (2014), "Moving towards a more dynamic business sector in Spain", OECD Economics Department Working Paper, forthcoming.

Fuentes, A. (2011), "Policies Towards a Sustainable Use of Water in Spain", OECD Economics Department Working Papers, No. 840, OECD Publishing, http://dx.doi.org/10.1787/5kgj310ggczten.

García Perea, P. and R. García Coria (2014), "Formación Profesional Dual e Inserción en el Área del Euro" (Dual vocational training and integration in the euro area), Boletín Económico, Banco de España, February. 
González-Gómez, F., M. Garciá-Rubio and J. Guardiola (2012), "Urban Water Service Policies and Management in Spain: Pending Issues", International Journal of Water Resources Development, Vol. 28, No. 1, Routledge, http://dx.doi.org/10.1080/07900627.2012.640927.

Government of Spain (2013), Estrategia Española de Ciencia y Tecnología y de Innovación 2013-2020 (Spanish Strategy for Science, Technology and Innovation 2013-2020), Ministerio de Economía y Competitividad.

Guellec, D. and B. van Pottelsberghe de la Potterie (2003), "The Impact of Public R\&D Expenditure on Business R\&D”, Economics of Innovation and New Technology, Vol. 12, No. 3, Taylor \& Francis Journals.

Haegland, T. and J. Moen (2007), "The Relationship Between the Norwegian R\&D Tax Credit Scheme and Other Innovation Policy Instruments", Reports 2007/45, Statistics Norway.

Hall, B.H., J. Mairesse and P. Mohnen (2010), "Measuring the Returns to R\&D”, in B.H. Hall and N. Rosenberg (eds.), Handbook of the Economics of Innovation, Vol. 2, Elsevier.

Hanushek, E.A. and L. Woessmann (2011), "The Economics of International Differences in Educational Achievement", in E.A. Hanushek, S. Machin and L. Woessmann (eds.), Handbook of the Economics of Education, Vol. 3, Elsevier.

Heckman, J. (2008), "Schools, Skills and Synapses", Economic Enquiry, Vol. 46, No. 3, http://dx.doi.org/10.1111/j.1465-7295.2008.00163.x.

Kluve, J. (2006), “The Effectiveness of European Active Labour Market Policy”, IZA Discussion Papers, No. 2018, Institute for the Study of Labor.

Lacuesta, A., S. Puente and E. Villanueva (2012), "The Schooling Response to a Sustained Increase in Low-skill Wages: Evidence from Spain 1989-2009”, Documentos de Trabajo, No. 1208, Banco de España.

Lawson, J. (2010), "European Energy Policy and the Transition to a Low-Carbon Economy", OECD Economics Department Working Papers, No. 779, OECD Publishing, http://dx.doi.org/10.1787/5kmd782tz0s5-en.

Martin, J. (2000), "What Works Among Active Labour Market Policies: Evidence from OECD Countries' Experiences", OECD Economic Studies, No. 30, OECD Publishing, http://dx.doi.org/10.1787/16097491.

Ménard, S. and F. Sellem (2010), "How Does Social Housing Affect the Rate of Equilibrium Unemployment?", paper presented at the 59th AFSE Congress (Association Française de Science Économique), 9-10 September, Nanterre.

Ministry of Labour and Immigration (2011), Encuesta de Calidad de Vida en el Trabajo (Survey of quality of life at work - database), Ministerio de Trabajo e Inmigración, www.empleo.gob.es/estadisticas/ecvt/welcome.htm

Mora-Sanguinetti, J.S. and A. Fuentes (2012), "An Analysis of Productivity Performance in Spain Before and During the Crisis: Exploring the Role of Institutions", OECD Economics Department Working Papers, No. 973, OECD Publishing, http://dx.doi.org/10.1787/5k9777lqshs5-en.

OECD (2014), OECD Employment Outlook 2014, OECD Publishing, http://dx.doi.org/10.1787/empl_outlook-2014-en. 
OECD (2013a), "Researchers on the Move: the Impact of Brain Circulation", OECD Publishing, www.oecd.org/sti/researchers-on-the-move-the-impact-of-brain-circulation.pdf.

OECD (2013b), Supporting Investment in Knowledge Capital, Growth and Innovation, OECD Publishing, http://dx.doi.org/10.1787/9789264193307-en.

OECD (2013c), "New Sources of Growth: Knowledge Based Capital, Key Analysis and Policy Conclusions, Synthesis Report", OECD Publishing.

OECD (2013d) OECD Science, Technology and Industry Scoreboard 2013: Innovation for Growth, OECD Publishing, http://dx.doi.org/10.1787/sti_scoreboard-2013-en.

OECD (2013e), Effective Carbon Prices, OECD Publishing, http://dx.doi.org/10.1787/9789264196964-en.

OECD (2013f), The 2012 Labour Market Reform in Spain: A Preliminary Assessment, OECD Publishing, http://dx.doi.org/10.1787/9789264213586-en.

OECD (2012a), Education at a Glance 2012: OECD Indicators, OECD Publishing, http://dx.doi.org/10.1787/eag-2012-en.

OECD (2012b), Equity and Quality in Education: Supporting Disadvantaged Students and School, OECD Publishing.

OECD (2012c), OECD Economic Surveys: Spain 2012, OECD Publishing, http://dx.doi.org/10.1787/eco_surveys-esp-2012-en.

OECD (2011a), OECD Regions at a Glance 2011, OECD Publishing, http://dx.doi.org/10.1787/reg_glance-2011-en.

OECD (2011b), OECD Reviews of Regional Innovation: Basque Country, Spain 2011, OECD Publishing, http://dx.doi.org/10.1787/9789264097377-en.

OECD (2011c), Water and Climate Change Adaptation: Policies to Navigate Uncharted Waters, OECD Studies on Water, OECD Publishing, http://dx.doi.org/10.1787/9789264200449-en.

OECD (2011d), Fostering Innovation for Green Growth, OECD Publishing, http://dx.doi.org/10.1787/9789264119925-en.

OECD (2010a), OECD Reviews of Regional Innovation: Catalonia, Spain 2010, OECD Publishing, http://dx.doi.org/10.1787/9789264082052-en.

OECD (2010b), "R\&D Tax Incentives: Rationale, Design, Evaluation”, Policy Brief, The Innovation Policy Platform, www.innovationpolicyplatform.org.

OECD (2010c), OECD Employment Outlook: Moving Beyond the Jobs Crisis, OECD Publishing, http://dx.doi.org/10.1787/empl_outlook-2010-en.

OECD (2009a), OECD Reviews of Tertiary Education: Spain 2009, OECD Publishing, http://dx.doi.org/10.1787/9789264039360-en.

OECD (2009b), "Helping Youth to Get a Firm Foothold in the Labour Market", paper for the Meeting of the Employment, Labour and Social Affairs Committee at Ministerial Level.

OECD (2008) OECD Economic Surveys: Spain 2008, OECD Publishing, http://dx.doi.org/10.1787/eco_surveys-esp-2008-en. 
OECD (2007), OECD Regions at a Glance 2007, OECD Publishing, http://dx.doi.org/10.1787/reg_glance2007-en.

Olmstead, S.M. and R.J. Staving (2008), “Comparing Price and Non-Price Approaches to Urban Water Conservation”, NBER Working Papers, No. 14147, National Bureau of Economic Research.

Petrick, S. and U.J. Wagner (2014), “The Impact Of Carbon Trading On Industry: Evidence From German Manufacturing Firms", Working Paper, available at: http://ssrn.com/abstract=2389800n.

Radziwill, A. (2012), "Improving Energy System Efficiency in the Czech Republic", OECD Economics Department Working Papers, No. 941, OECD Publishing, http://dx.doi.org/10.1787/5k9gsh6mcgzpen.

Scarpetta, S., A. Sonnet and T. Manfredi (2010), "Rising Youth Unemployment During The Crisis: How to Prevent Negative Long-term Consequences on a Generation?", OECD Social, Employment and Migration Working Papers, No. 106, OECD Publishing, http://dx.doi.org/10.1787/5kmh79zb2mmven.

Wallsten, S. (2000), "The Effects of Government-Industry R\&D Programmes on Private R\&D: The Case of the Small Business Innovation Research Program", Rand Journal of Economics, Vol. 31, Spring.

Westmore, B. (2013), "R\&D, patenting and Productivity: the Role of Public Policy", OECD Economics Department Working Papers, No. 1047, OECD Publishing, http://dx.doi.org/10.1787/5k46h2rfb4f3en.

Wölfl, A. (2013), "Improving Employment Prospects for Young Workers in Spain”, OECD Economics Department Working Papers, No. 1040, OECD Publishing, http://dx.doi.org/10.1787/5k487n7hg08s-en.

World Bank (2011), School Autonomy and Accountability, System Assessment and Benchmarking for Education Results, World Bank.

World Bank (2009), Decentralized Decision-Making in Schools, Directions in Development, World Bank. 
Annex 1.A1

\section{Medium-term growth simulations}

The OECD's long-term growth model, a calibrated production-function based model of the economy, described in (Johansson et al., 2013) was used to quantify illustrative scenarios for the effects of improving three key drivers of trend growth, in which Spain is currently under-performing relative to the OECD average (education, business research and development [R\&D], structural unemployment) and on which, as discussed above, government policy can play a large role. Three main scenarios were run relative to the model baseline:

- Raising Spain's schooling to OECD median schooling by 2035 (adds one year to the baseline schooling by 2035).

- Increasing business R\&D to the median and 75\% percentile of the OECD by 2035 . This assumes that a $1 \%$ increase in business $R \& D$ intensity results in around a $0.5 \%$ increase in total factor productivity (TFP) growth and that a shock to business R\&D takes roughly five years to be fully transmitted to long-run TFP (Griffith et al., 2004; Guellec and van Pottelsberghe, 2001). Spain's GDP (and GDP per capita) would be higher by $11 \%$ and $18 \%$ respectively by 2060 .

- $\quad$ Reducing the Spanish non-accelerating inflation rate of unemployment (NAIRU) to the OECD median by 2035 (NAIRU around 7 percentage points lower by 2035 compared to baseline).

\section{Bibliography}

Griffith, R., S. Redding and J. Van Reenen (2004), "Mapping the Two faces of R\&D: Productivity Growth in a Panel of OECD Industries", The Review of Economics and Statistics, Vol. 86, No. 4, MIT Press.

Guellec, D. and B. van Pottelsberghe de la Potterie (2001), "R\&D and Productivity Growth: Panel Data Analysis of 16 OECD Countries", OECD Economic Studies, Vol. 2001/2, http://dx.doi.org/10.1787/16097491.

Johansson, A. et al. (2013), "Long-Term Growth Scenarios", OECD Economics Department Working Papers, No. 1000, OECD Publishing, http://dx.doi.org/10.1787/5k4ddxpr2fmr-en. 
ECO/WKP(2014)68

\section{WORKING PAPERS}

The full series of Economics Department Working Papers can be consulted at www.oecd.org/eco/workingpapers

1171. The internet economy - regulatory challenges and practices

(October 2014) by Isabell Koske, Rosamaria Bitetti, Isabelle Wanner and Ewan Sutherland

1170. A revival of the private rental sector of the housing market? Lessons from Germany, Finland, the Czech Republic and the Netherlands

(October 2014) by Rik de Boer and Rosamaria Bitetti

1169. Secular stagnation: evidence and implications for economic policy

(October 2014) by Łukasz Rawdanowicz, Romain Bouis, Kei-Ichiro Inaba and

Ane Kathrine Christensen

1168. Investment gaps after the crisis

(October 2014) by Christine Lewis, Nigel Pain, Jan Strasky and Fusako Menkyna

1167. Factors behind the decline in real long-term government bond yield

(October 2014) by Romain Bouis, Kei-Ichiro Inaba, Łukasz Rawdanowicz and

Ane Kathrine Christensen

1166. The effect of the global financial crisis on the OECD potential output

(October 2014) by Patrice Ollivaud and David Turner

1165. Determinants of households' investment in energy efficiency and renewables - evidence from the OECD Survey on household environmental behaviour and attitudes

(October 2014) by Nadia Ameli and Nicola Brandt

1164. Addressing high household debt in Korea

(September 2014) by Randall S. Jones and Myungkyoo Kim

1163. Reducing the high rate of poverty among the elderly in Korea

(September 2014) by Randall S. Jones and Satoshi Urasawa

1162. Promoting the financing of SMEs and start-ups in Korea

(September 2014) by Randall S. Jones and Myungkyoo Kim

1161. Fostering inclusive growth by promoting structural change in the business sector

(September 2014) by Rauf Gönenç, Oliver Röhn, Vincent Koen and Fethi Ögünç

1160. Reducing macroeconomic imbalances in Turkey

(September 2014) by Oliver Röhn, Rauf Gönenç, Vincent Koen and Evren Erdoğan Coşar

1159. Reinvigorating the EU Single Market

(September 2014) by Jean-Marc Fournier.

1158. An exploration of the determinants of the subjective well-being of Americans during the great recession

(August 2014) by Aida Caldera Sánchez and Caroline Tassot. 
1157. Boosting the development of efficient SMEs in the Netherlands (September) by Rafał Kierzenkowski and Jochebed Kastaneer

1156. Making the banking sector more resilient and reducing household debt in the Netherlands (September 2014) by Rafał Kierzenkowski, Olena Havrylchyk and Pierre Beynet

1155. US long term interest rates and capital flows to emerging economies (July 2014) by Eduardo Olaberria

1154. Productivity measurement with natural capital and bad outputs (July 2014) by Nicola Brandt, Paul Schreyer and Vera Zipperer

1153. Reducing income inequality and poverty and promoting social mobility in Korea (July 2014) by Randall S. Jones and Satoshi Urasawa

1152. Fostering a creative economy to drive Korean growth (July 2014) by Randall S. Jones and Myungkyoo Kim

1151. Economic uncertainties and their impact on activity in Greece compared with Ireland and Portugal

(July 2014) by Jan-David Schneider and Claude Giorno

1150. Workplace stress in the United States: issues and policies

(July 2014) by Michael Darden

1149. Taxing the rent of non-renewable resource sectors: a theoretical note (July 2014) by Julien Daubanes and Saraly Andrade de Sá

1148. Health, work and working conditions: a review of the European economic literature (July 2014) by Thomas Barnay

1147. Making the best of new energy resources in the United States (July 2014) by Douglas Sutherland

1146. Improving well-being in the United States (July 2014) by Aida Caldera Sánchez, Patrick Lenain and Sarah Fléche

1145. Deconstructing Canada's housing markets: finance, affordability and urban sprawl (July 2014) by Calista Cheung Restructurer les marchés canadiens du logement: financements, accessibilité financière et étalement urbain (Juillet 2014) par Calista Cheung 